\title{
Synthesis of Rovafovir Etalafenamide (Part I): Active Pharmaceutical Ingredient Process Development, Scale-Up, and Impurity Control Strategy
}

\section{Supporting Information}

Eric A. Standley, ${ }^{* \dagger}$ Dustin A. Bringley, ${ }^{\dagger}$ Selcuk Calimsiz, ${ }^{\dagger}$ Jeffrey D. Ng, ${ }^{\dagger}$ Keshab Sarma, ${ }^{\dagger}$ Jinyu Shen, ${ }^{\dagger}$ David A. Siler, ${ }^{\dagger}$ Andrea Ambrosi, ${ }^{\dagger}$ Wen-Tau T. Chang, ${ }^{\dagger}$ Anna Chiu, ${ }^{\dagger}$ Jason A. Davy, ${ }^{\dagger}$ Ian J. Doxsee,,$^{\dagger}$ Mihaela M. Esanu, ${ }^{+}$Jeffrey A. O. Garber, ${ }^{+}$Youri Kim, ${ }^{+}$Bernard Kwong, ${ }^{\ddagger}$ Olga Lapina, ${ }^{\dagger}$ Edmund Leung,,+ Lennie Lin, ${ }^{+}$Andrew Martins, ${ }^{+}$Jenny Phoenix, ${ }^{*}$ Jaspal Phull,,+ Benjamin J. Roberts, ${ }^{\dagger}$ Bing Shi, ${ }^{\dagger}$ Olivier St-Jean,,$^{\dagger}$ Xiang Wang, ${ }^{\dagger}$ Li Wang, ${ }^{\dagger}$ Nande Wright,,${ }^{\dagger}$ Guojun Yu ${ }^{\dagger}$

${ }^{\dagger}$ Gilead Sciences, Inc., Process Chemistry, 333 Lakeside Drive, Foster City, CA, 94404, USA

Gilead Alberta ULC, Process Development, 1021 Hayter Road NW, Edmonton, Alberta T6S 1A1, Canada

\section{Table of Contents}

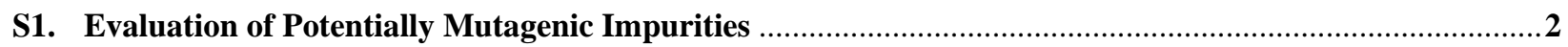

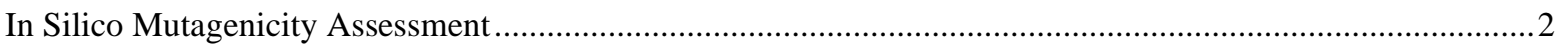

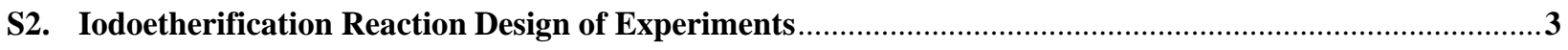

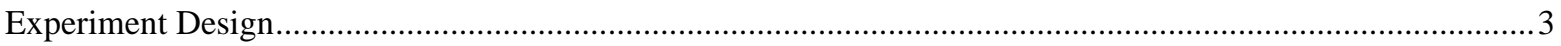

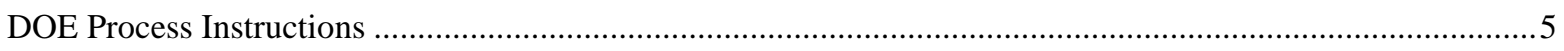

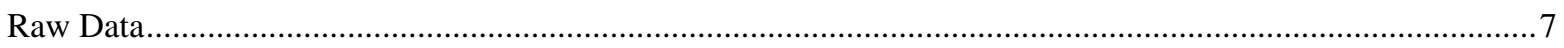

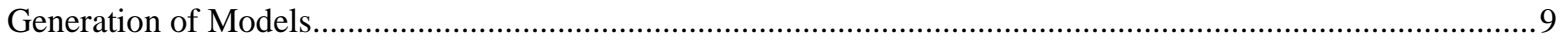

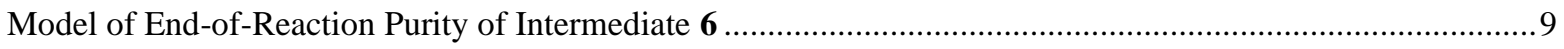

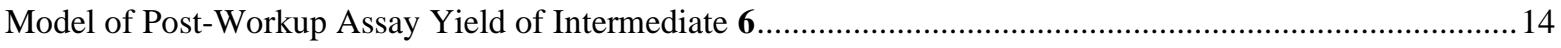

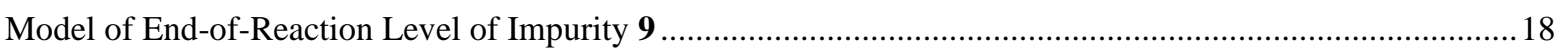

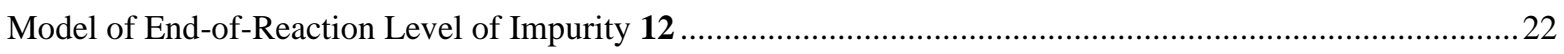

Comparison of Iodoetherification Reaction Performance Before and After DOE .....................................26

S3. Approaches Taken to Mitigate Emulsion in Iodoetherification Process Workup ...............................27

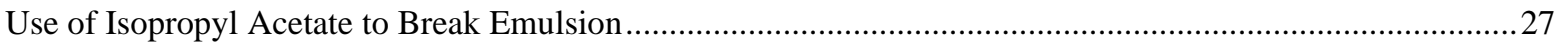

Use of a Cellulose Depth Filter to Break Emulsion ..................................................................................28

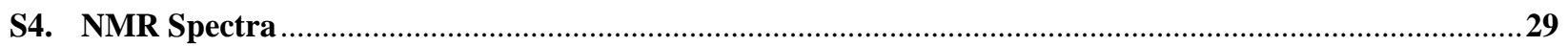

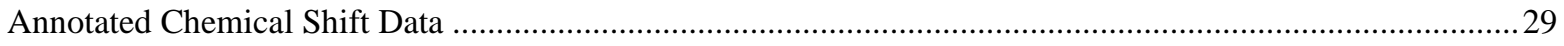




\section{S1. Evaluation of Potentially Mutagenic Impurities}

\section{In Silico Mutagenicity Assessment}

An in silico assessment for potential mutagenic impurities was carried out, which flagged seven species. Testing in the Ames reverse mutation assay was undertaken for compounds 4, DIHD, S2/S3, and S4/S5, which demonstrated them to be non-mutagenic. These species were therefore treated as ICH Class 5 impurities per ICH M7 guidance. Impurity $\mathbf{S 1}$ was determined to be non-mutagenic by expert opinion and was also controlled as an ICH Class 5 impurity.

Table S1.

Impurities Evaluated for Potential Mutagenicity

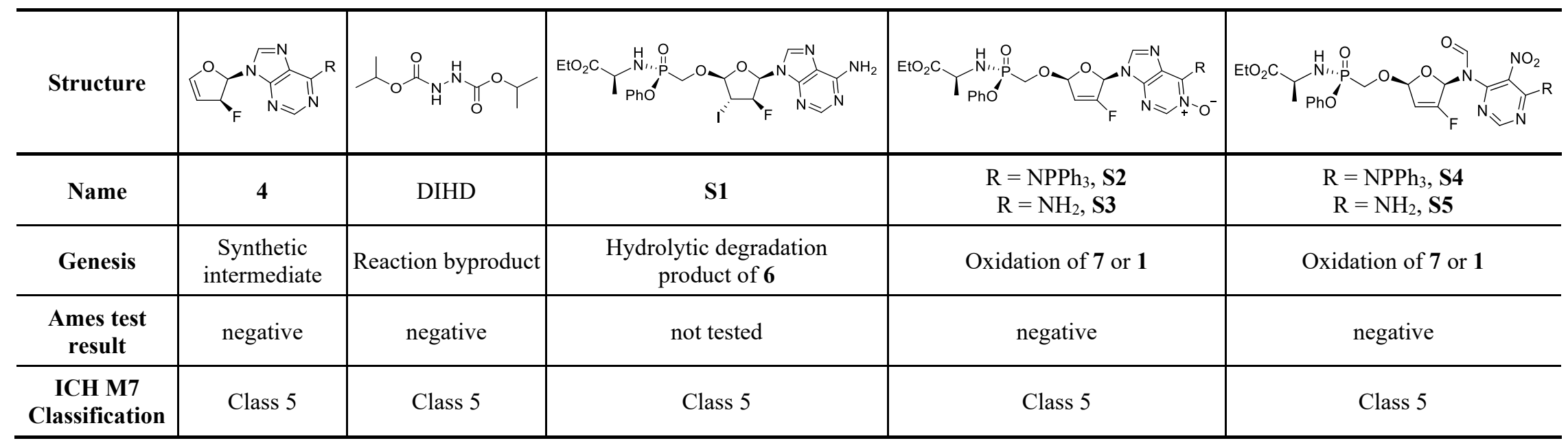




\section{S2. Iodoetherification Reaction Design of Experiments}

\section{Experiment Design}

The Design of Experiments (DOE) study performed for the iodoetherification reaction was created in the JMP13 software package. A custom, D-optimal design was selected which included five factors as main effects as well as interaction effects between all five factors and all quadratic effects. Each factor was studied at three levels. The study consisted of 28 experiments, was run by a single operator, and no blocking was used. After completing the original set of 28 experiments, an augment of 8 additional experiments was created to lower the temperature range studied from $10{ }^{\circ} \mathrm{C}$ to $5{ }^{\circ} \mathrm{C}$. Blocking was not used, as analysis of the residuals revealed no statistical differences between the first 28 experiments and the 8 experiments of the augment. The composite, augmented DOE was analyzed for its statistical power and found to be adequate to detect even weak to moderate effects across all main effects, interaction terms, and quadratic terms (Table S2).

Table S2.

Power Analysis of Augmented DOE Study

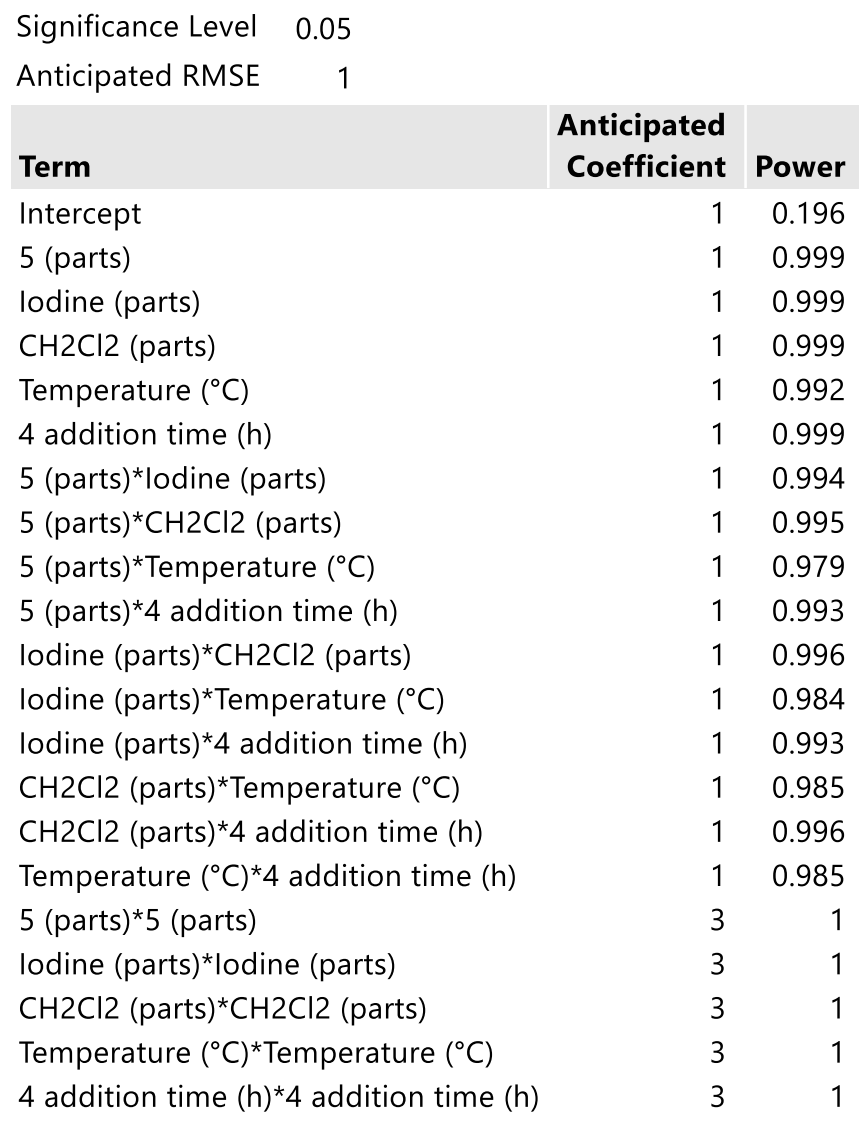


The design also provided adequate coverage of the design space, indicating it was appropriately statistically powered (Table $\mathbf{S 3}$ ).

\section{Table S3.}

\section{Fraction of Design Space Plot for DOE Study}

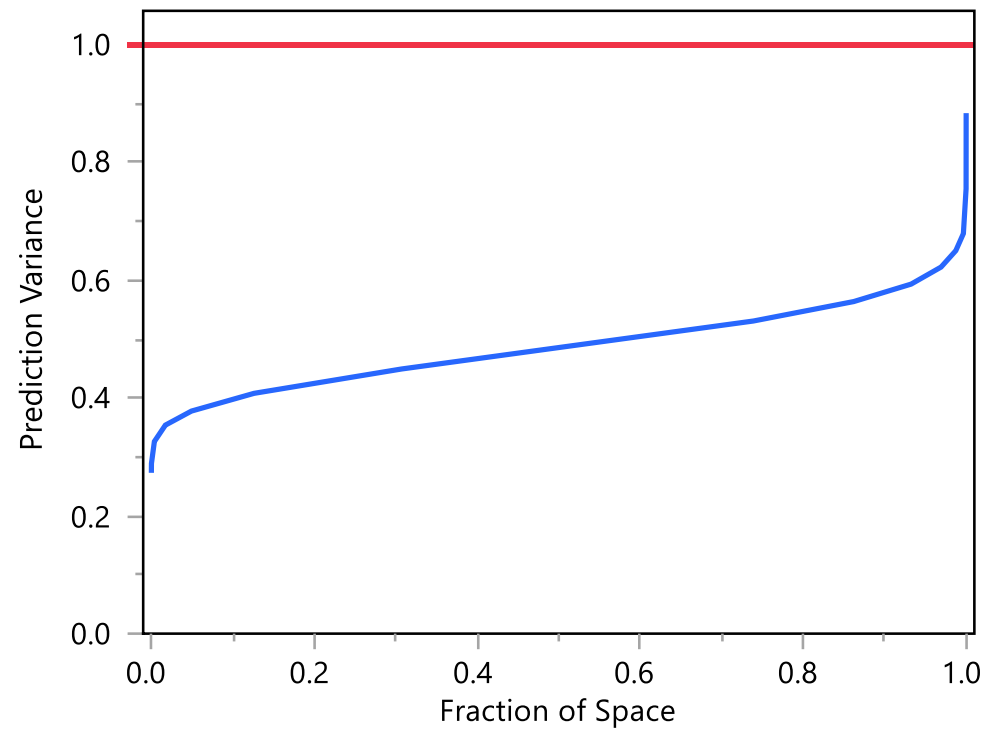

The ranges studied in this experiment are shown in Table S4. Ranges were selected based on existing process knowledge and practical limitations such as the minimum stirring volume in a reactor.

Table S4.

DOE Study Factors and Ranges

\begin{tabular}{l|c|c|c}
\hline Factor & Low & Middle & High \\
\hline Charge of 5 & $\begin{array}{c}0.60 \mathrm{~kg} / \mathrm{kg} \\
(1.10 \text { equiv })\end{array}$ & $\begin{array}{c}0.85 \mathrm{~kg} / \mathrm{kg} \\
(1.55 \mathrm{equiv})\end{array}$ & $\begin{array}{c}1.10 \mathrm{~kg} / \mathrm{kg} \\
(2.00 \mathrm{equiv})\end{array}$ \\
\hline Charge of iodine & $\begin{array}{c}1.8 \mathrm{~kg} / \mathrm{kg} \\
(3.71 \text { equiv })\end{array}$ & $\begin{array}{c}2.7 \mathrm{~kg} / \mathrm{kg} \\
(5.57 \mathrm{equiv})\end{array}$ & $\begin{array}{c}3.6 \mathrm{~kg} / \mathrm{kg} \\
(7.42 \mathrm{equiv})\end{array}$ \\
\hline Charge of $\mathrm{CH}_{2} \mathrm{Cl}_{2}$ & $\begin{array}{c}1.3 \mathrm{~kg} / \mathrm{kg} \\
(1.0 \mathrm{~L} / \mathrm{kg})\end{array}$ & $\begin{array}{c}2.9 \mathrm{~kg} / \mathrm{kg} \\
(2.2 \mathrm{~L} / \mathrm{kg})\end{array}$ & $\begin{array}{c}4.5 \mathrm{~kg} / \mathrm{kg} \\
(3.4 \mathrm{~L} / \mathrm{kg})\end{array}$ \\
\hline Reaction temperature & $5^{\circ} \mathrm{C}^{\mathrm{a}}$ & $22.5^{\circ} \mathrm{C}$ & $35^{\circ} \mathrm{C}$ \\
\hline Addition time of $\mathbf{4}$ & $5 \mathrm{~h}$ & $10 \mathrm{~h}$ & $15 \mathrm{~h}$ \\
\hline
\end{tabular}

\footnotetext{
a The low temperature originally studied was $10{ }^{\circ} \mathrm{C}$, which was later lowered to $5^{\circ} \mathrm{C}$ by augmenting the experimental design.
} 


\section{DOE Process Instructions}

Each experiment was run according to the following procedure. The procedure is based on a scaling factor of $10.0 \mathrm{~g}$ of 4 .

1. Prepare a $100 \mathrm{~mL}$ (nominal volume) jacketed, cylindrical glass reactor with a 5-port glass lid, 3-blade, glass retreat curve impeller, 1/8" diameter PFA-coated thermocouple, 19/22 ST reflux condenser (jacket $10^{\circ} \mathrm{C}$ ) with nitrogen inlet, and a bottom drain valve.

2. Cap all unused inlet ports and set the jacket to $22.5^{\circ} \mathrm{C}$.

3. Charge iodine $(1.8,2.7$, or $3.6 \mathrm{~kg} / \mathrm{kg}$ as indicated), dichloromethane $(1.3,2.9$, or $4.5 \mathrm{~kg} / \mathrm{kg}$ as indicated), and $N, O$-bis(trimethylsilyl)acetamide $(0.01 \mathrm{~kg} / \mathrm{kg})$ to reactor and inert with nitrogen.

4. Start agitation at $300 \mathrm{rpm}$ and age for 45 minutes. Proceed to the following step during this age period.

5. Charge a $100 \mathrm{~mL}$ media bottle with $4(12 \mathrm{~g})$, dichloromethane $(48 \mathrm{~g}), \quad N, O-$ bis(trimethylsilyl)acetamide (0.12 g), and a 1/2" PTFE-coated magnetic stir bar. Stir at 1000 rpm for 15 minutes. This solution contains $10.0 \mathrm{~g}$ of 4 per $37.8 \mathrm{~mL}$ as determined experimentally.

6. After the 45 minute age period from Step 4 is complete, charge $\mathbf{5}$ to the reactor.

7. Set the jacket temperature to obtain an internal temperature of $5.0 \pm 1.0,10.0 \pm 1.0,22.5 \pm$ 1.0 , or $35.0 \pm 1.0{ }^{\circ} \mathrm{C}$ as required and age for 15 minutes.

8. Transfer $40 \mathrm{~mL}$ of the dichloromethane solution of 4 prepared in step 5 to a $50 \mathrm{~mL}$ glass syringe (Hamilton P/N 85020) and affix a PFA transfer line $\left(1 / 16^{\text {th }}\right.$ inch $O D, 0.020$ inch ID) to the syringe.

9. Place the syringe onto a syringe pump (Chemyx Fusion 200) and purge the transfer line of air.

10. Insert the transfer line through a PTFE adapter or septum and position it so that the solution will drip directly into the reaction mixture.

11. Start the addition of $37.8 \mathrm{~mL}$, equivalent to $10.0 \mathrm{~g}$, of the stock solution of 4 over the specified time $(5,10$, or $15 \mathrm{~h})$.

12. Once addition has completed, leave the transfer line in place and do not rinse forward.

13. Age the reaction for $14 \mathrm{~h}$.

14. Approximately 1 hour prior to the expiration of the age period from Step 13, prepare a quench solution in a $500 \mathrm{~mL}$ Erlenmeyer flask consisting of sodium sulfite, sodium bicarbonate, and water. The amounts used are adjusted according to the amount of iodine used in the reaction to ensure complete quench of the iodine while maintaining neutral $\mathrm{pH}$.

\begin{tabular}{c|c|c|c}
\hline Iodine charge & $\mathbf{N a}_{2} \mathbf{S O}_{3}$ & $\mathbf{N a H C O}_{3}$ & Tap water \\
\hline $1.8 \mathrm{~kg} / \mathrm{kg}$ & $13.3 \mathrm{~g}$ & $12 \mathrm{~g}$ & $133 \mathrm{~g}$ \\
\hline $2.7 \mathrm{~kg} / \mathrm{kg}$ & $20 \mathrm{~g}$ & $18 \mathrm{~g}$ & $200 \mathrm{~g}$ \\
\hline $3.6 \mathrm{~kg} / \mathrm{kg}$ & $26.7 \mathrm{~g}$ & $24 \mathrm{~g}$ & $267 \mathrm{~g}$ \\
\hline
\end{tabular}

15. Add a 1.5" magnetic stir bar and stir at $500 \mathrm{rpm}$ for not less than 10 minutes.

16. At completion of the 14 hour age period from Step 13, sample the reaction for $\%$ AN purity by UPLC.

a. Prepare a quench mixture in a 1 dram vial consisting of $100 \mathrm{mg}$ of sodium sulfite, $1 \mathrm{~mL}$ of tap water, and $0.5 \mathrm{~mL}$ of dichloromethane. 
b. Using a PFA transfer line affixed to a $1 \mathrm{~mL}$ syringe, withdraw $100 \mu \mathrm{L}$ of sample.

c. Inject sample into the quench mixture, cap, and shake vigorously for 10 to 30 seconds or until the iodine color completely fades.

d. Using a pipette, withdraw the lower, organic layer and transfer it to a $20 \mathrm{~mL}$ scintillation vial.

e. Evaporate the dichloromethane using a rotary evaporator and reconstitute the residue with $15 \mathrm{~mL}$ of acetonitrile.

f. Submit the sample for analysis by UPLC.

17. While stirring the quench mixture at $500 \mathrm{rpm}$, discharge the reaction mixture into the quench mixture over a target time of 15 to 60 minutes to maintain acceptable foaming.

18. Rinse the reactor forward with $100 \mathrm{~mL}$ of dichloromethane.

19. Continue agitating the quenched reaction mixture for 30 minutes.

20. Transfer the mixture to a $500 \mathrm{~mL}$ separatory funnel and rinse forward with $30 \mathrm{~mL}$ dichloromethane.

21. Allow the phases to separate until a distinct phase separation is obtained (typical time 10 minutes).

22. Drain the lower, organic layer to a $500 \mathrm{~mL}$ Erlenmeyer flask.

23. Charge $30 \mathrm{~g}$ of dichloromethane and shake the separatory funnel to perform a second extraction.

24. Allow the phases to settle, then discharge the organic layer to the same Erlenmeyer flask.

25. Charge $15 \mathrm{~g}$ of magnesium sulfate to the flask and stir for not less than 30 seconds.

26. Filter the mixture through a $10 \mu \mathrm{m}$ polyethylene fritted funnel fitted with a Celite insert (ChemGlass P/N OP-6603-13) into a tared $500 \mathrm{~mL}$ round bottom flask.

27. Rinse the Erlenmeyer flask forward with $100 \mathrm{~mL}$ dichloromethane through the filter.

28. Obtain the net weight of the solution and determine the assay yield.

a. Fill two volumetric flasks each with $45 \pm 2 \mathrm{~mL}$ of acetonitrile.

b. Sample and accurately weigh approximately $0.4 \%$ of the total solution mass of the dichloromethane solution of $\mathbf{6}$ into each of the volumetric flasks.

c. Dilute to volume with acetonitrile and analyze by UPLC for \% AN purity and assay yield by external standard. 


\section{Raw Data}

The raw data from the DOE are presented in Table S5. Experiments 29-36 are the eight runs added in the augment.

Table S5.

Raw Data for Iodoetherification DOE

$\mathrm{EtO}_{2} \mathrm{C} \overbrace{\mathrm{PhO}^{\mathrm{N}}}^{\mathrm{H}} \stackrel{\mathrm{O}}{\mathrm{P}} \mathrm{COH}^{\mathrm{O}}$

5

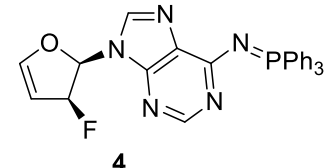

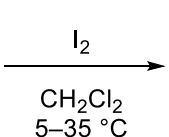

$\mathrm{CH}_{2} \mathrm{Cl}_{2}$ $\mathrm{EtO}_{2} \mathrm{C}{ }_{\mathrm{PhO}}^{\mathrm{N}}$
$\mathrm{EtO}_{2} \mathrm{C}{ }_{\mathrm{PhO}}^{\mathrm{N}}$

$$
\mathrm{EtO}_{2} \mathrm{C} \mathrm{PhO}_{-\mathrm{N}}^{\mathrm{N}}
$$

\begin{tabular}{|c|c|c|c|c|c|c|c|c|c|c|c|c|}
\hline \multirow{2}{*}{ Experiment } & \multicolumn{5}{|c|}{ Reaction Parameters } & \multicolumn{3}{|c|}{ End of Reaction Purity ( $\%$ AN) } & \multicolumn{3}{|c|}{$\begin{array}{l}\text { Purity after Quench and } \\
\text { Workup (\% AN) }\end{array}$} & \multirow{2}{*}{$\begin{array}{c}6 \text { assay } \\
\text { yield }(\%)\end{array}$} \\
\hline & $\begin{array}{c}\mathbf{5} \\
(\mathrm{kg} / \mathrm{kg})\end{array}$ & $\begin{array}{l}\text { Iodine } \\
(\mathrm{kg} / \mathrm{kg})\end{array}$ & $\begin{array}{l}\mathrm{CH}_{2} \mathrm{Cl}_{2} \\
(\mathrm{~kg} / \mathrm{kg})\end{array}$ & $\begin{array}{c}\text { Temperature } \\
\left({ }^{\circ} \mathrm{C}\right)\end{array}$ & $\begin{array}{l}\text { Addition time } \\
\text { of } 4(\mathrm{~h})\end{array}$ & 6 & 9 & 12 & 6 & 9 & 12 & \\
\hline 1 & 0.85 & 2.7 & 4.5 & 10 & 10 & 82.38 & 0.33 & 0.06 & 81.57 & 0.34 & 0.07 & $84.0 \%$ \\
\hline 2 & 0.60 & 2.7 & 2.9 & 35 & 5 & 73.29 & 0.41 & 0.34 & 73.25 & 0.40 & 0.34 & $75.5 \%$ \\
\hline 3 & 1.10 & 2.7 & 1.3 & 10 & 5 & 82.62 & 0.53 & 0.06 & 82.07 & 0.53 & 0.07 & $87.7 \%$ \\
\hline 4 & 0.60 & 1.8 & 1.3 & 35 & 10 & 57.79 & 0.39 & 1.00 & 58.47 & 0.38 & 1.00 & $56.7 \%$ \\
\hline 5 & 0.60 & 3.6 & 1.3 & 10 & 15 & 78.47 & 0.33 & 0.13 & 78.09 & 0.31 & 0.14 & $79.7 \%$ \\
\hline 6 & 0.60 & 1.8 & 4.5 & 22.5 & 5 & 62.22 & 0.24 & 0.14 & 61.05 & 0.26 & 0.21 & $58.8 \%$ \\
\hline 7 & 1.10 & 1.8 & 2.9 & 22.5 & 10 & 74.51 & 0.47 & 0.12 & 74.22 & 0.47 & 0.12 & $77.4 \%$ \\
\hline 8 & 0.85 & 3.6 & 1.3 & 22.5 & 5 & 82.54 & 0.50 & 0.05 & 82.50 & 0.51 & 0.05 & $86.8 \%$ \\
\hline 9 & 0.60 & 3.6 & 1.3 & 35 & 5 & 70.61 & 0.37 & 0.21 & 71.37 & 0.37 & 0.21 & $74.8 \%$ \\
\hline 10 & 0.85 & 3.6 & 2.9 & 35 & 15 & 74.32 & 0.36 & 0.31 & 74.04 & 0.35 & 0.30 & $76.5 \%$ \\
\hline 11 & 1.10 & 3.6 & 4.5 & 35 & 5 & 80.08 & 0.47 & 0.09 & 79.18 & 0.45 & 0.09 & $86.3 \%$ \\
\hline 12 & 0.60 & 3.6 & 4.5 & 22.5 & 15 & 78.21 & 0.31 & 0.18 & 77.35 & 0.31 & 0.19 & $79.7 \%$ \\
\hline
\end{tabular}




\begin{tabular}{|c|c|c|c|c|c|c|c|c|c|c|c|c|}
\hline \multirow{2}{*}{ Experiment } & \multicolumn{5}{|c|}{ Reaction Parameters } & \multicolumn{3}{|c|}{ End of Reaction Purity (\% AN) } & \multicolumn{3}{|c|}{$\begin{array}{c}\text { Purity after Quench and } \\
\text { Workup (\% AN) }\end{array}$} & \multirow{2}{*}{$\begin{array}{c}6 \text { assay } \\
\text { yield }(\%)\end{array}$} \\
\hline & $\begin{array}{c}5 \\
(\mathrm{~kg} / \mathrm{kg})\end{array}$ & $\begin{array}{l}\text { Iodine } \\
(\mathrm{kg} / \mathrm{kg})\end{array}$ & $\begin{array}{l}\mathrm{CH}_{2} \mathrm{Cl}_{2} \\
(\mathrm{~kg} / \mathrm{kg})\end{array}$ & $\begin{array}{l}\text { Temperature } \\
\left({ }^{\circ} \mathrm{C}\right)\end{array}$ & $\begin{array}{l}\text { Addition time } \\
\quad \text { of } 4(h)\end{array}$ & 6 & 9 & 12 & 6 & 9 & 12 & \\
\hline 13 & 1.10 & 3.6 & 2.9 & 10 & 5 & 83.50 & 0.42 & 0.08 & 83.01 & 0.44 & 0.08 & $89.2 \%$ \\
\hline 14 & 0.85 & 1.8 & 4.5 & 35 & 5 & 64.89 & 0.38 & 0.50 & 63.61 & 0.39 & 0.52 & $63.3 \%$ \\
\hline 15 & 0.60 & 2.7 & 1.3 & 22.5 & 15 & 75.60 & 0.36 & 0.22 & 76.02 & 0.37 & 0.23 & $78.7 \%$ \\
\hline 16 & 0.60 & 3.6 & 4.5 & 35 & 10 & 69.97 & 0.32 & 0.25 & 69.90 & $\mathrm{n} / \mathrm{a}$ & 0.26 & $72.7 \%$ \\
\hline 17 & 0.60 & 1.8 & 4.5 & 35 & 15 & 55.76 & 0.33 & 0.89 & 55.29 & 0.35 & 0.90 & $53.1 \%$ \\
\hline 18 & 1.10 & 1.8 & 4.5 & 10 & 5 & 70.73 & 0.37 & 0.11 & 70.22 & 0.41 & 0.10 & $72.0 \%$ \\
\hline 19 & 1.10 & 3.6 & 1.3 & 10 & 10 & 83.64 & 0.53 & 0.02 & 82.86 & 0.53 & 0.01 & $90.7 \%$ \\
\hline 20 & 0.60 & 1.8 & 4.5 & 10 & 15 & 67.19 & 0.26 & 0.07 & 66.47 & 0.25 & 0.07 & $65.2 \%$ \\
\hline 21 & 1.10 & 1.8 & 4.5 & 35 & 15 & 56.89 & 0.34 & 1.32 & 55.84 & 0.35 & 1.34 & $56.1 \%$ \\
\hline 22 & 1.10 & 3.6 & 1.3 & 35 & 15 & 73.34 & 0.44 & 0.30 & 72.57 & 0.43 & 0.29 & $79.9 \%$ \\
\hline 23 & 1.10 & 1.8 & 1.3 & 10 & 15 & 79.47 & 0.51 & 0.07 & 79.28 & 0.50 & 0.06 & $85.2 \%$ \\
\hline 24 & 1.10 & 1.8 & 1.3 & 35 & 5 & 71.92 & 0.62 & 0.61 & 71.76 & 0.61 & 0.62 & $74.7 \%$ \\
\hline 25 & 0.60 & 1.8 & 1.3 & 10 & 5 & 66.56 & 0.29 & 0.09 & 66.01 & 0.31 & 0.10 & $64.3 \%$ \\
\hline 26 & 1.10 & 3.6 & 4.5 & 10 & 15 & 81.95 & 0.37 & 0.00 & 81.35 & 0.39 & 0.00 & $87.6 \%$ \\
\hline 27 & 0.60 & 3.6 & 4.5 & 10 & 5 & 72.02 & 0.23 & 0.37 & 71.35 & 0.27 & 0.39 & $71.9 \%$ \\
\hline 28 & 0.85 & 1.8 & 1.3 & 35 & 15 & 54.24 & 0.35 & 1.84 & 54.58 & 0.35 & 1.80 & $54.6 \%$ \\
\hline 29 & 1.10 & 1.8 & 4.5 & 5 & 5 & 68.54 & 0.36 & 0.03 & 68.25 & 0.37 & 0.05 & $69.2 \%$ \\
\hline 30 & 0.85 & 1.8 & 1.3 & 5 & 5 & 71.27 & 0.37 & 0.05 & 70.96 & 0.39 & 0.07 & $70.5 \%$ \\
\hline 31 & 0.60 & 1.8 & 2.9 & 5 & 15 & 66.23 & 0.25 & 0.06 & 65.80 & 0.26 & 0.06 & $67.3 \%$ \\
\hline 32 & 0.60 & 3.6 & 4.5 & 5 & 5 & 65.61 & 0.24 & 0.18 & 65.41 & 0.24 & 0.19 & $64.2 \%$ \\
\hline 33 & 1.10 & 3.6 & 4.5 & 5 & 15 & 82.13 & 0.35 & 0.02 & 81.47 & 0.36 & 0.03 & $86.8 \%$ \\
\hline 34 & 0.60 & 3.6 & 1.3 & 5 & 10 & 74.93 & 0.30 & 0.13 & 75.09 & 0.31 & 0.14 & $76.2 \%$ \\
\hline 35 & 1.10 & 2.7 & 1.3 & 5 & 15 & 81.26 & 0.46 & 0.03 & 80.91 & 0.47 & 0.02 & $86.9 \%$ \\
\hline 36 & 1.10 & 2.7 & 4.5 & 35 & 15 & 70.94 & 0.42 & 0.68 & 70.71 & 0.41 & 0.67 & $76.5 \%$ \\
\hline
\end{tabular}

Page 8 of 49 


\section{Generation of Models}

Standard least squares regression models were independently constructed for each response. The models were evaluated for outliers using studentized residuals, and outliers were defined as having absolute studentized residuals $>2.576$, corresponding to a $99 \%$ confidence interval. No further model refinement was undertaken after outlier removal.

\section{Model of End-of-Reaction Purity of Intermediate 6}

The distribution, quantiles, and summary statistics for the end-of-reaction purity of $\mathbf{6}$ are illustrated in Figure S1.

Figure S1. Distribution of Responses for End-of-Reaction Purity of Intermediate 6

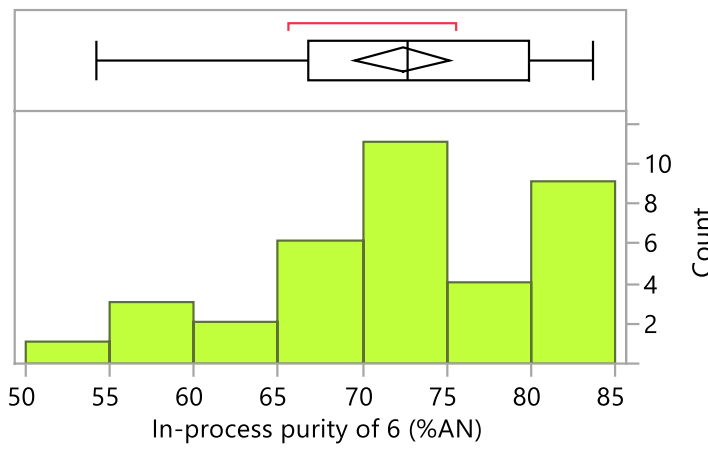

\begin{tabular}{|c|c|c|}
\hline \multicolumn{3}{|c|}{ Quantiles } \\
\hline $100.0 \%$ & maximum & 83.64 \\
\hline $99.5 \%$ & & 83.64 \\
\hline $97.5 \%$ & & 83.64 \\
\hline $90.0 \%$ & & 82.564 \\
\hline $75.0 \%$ & quartile & 79.9275 \\
\hline $50.0 \%$ & median & 72.655 \\
\hline $25.0 \%$ & quartile & 66.7175 \\
\hline $10.0 \%$ & & 57.52 \\
\hline $2.5 \%$ & & 54.24 \\
\hline $0.5 \%$ & & 54.24 \\
\hline $0.0 \%$ & minimum & 54.24 \\
\hline
\end{tabular}

\begin{tabular}{|l|r|}
\hline \multicolumn{2}{|l|}{ Summary Statistics } \\
\hline Mean & 72.378333 \\
Std Dev & 8.3212652 \\
Std Err Mean & 1.3868775 \\
Upper 95\% Mean & 75.193844 \\
Lower 95\% Mean & 69.562822 \\
N & 36 \\
Sum & 2605.62 \\
Variance & 69.243454 \\
CV & 11.496901 \\
N Missing & 0 \\
&
\end{tabular}

A standard least squares regression was performed on the augmented dataset. The model generated was statistically significant with high $\mathrm{R}^{2}$ and $\mathrm{R}^{2}$ adj values, but analysis of the studentized residuals revealed experiment 23 to be an outlier at the $99 \%$ confidence interval. A new model excluding experiment 23 was constructed for which the actual-by-predicted plot is shown in Figure S2. Further statistical details of the model, including summary of fit and analysis of variance, are provided in Table S6 and Table S7, respectively. 
Figure S2.

Table S6.

Table S7.
Actual-by-Predicted Plot for Model of End-of-Reaction Purity of Intermediate 6

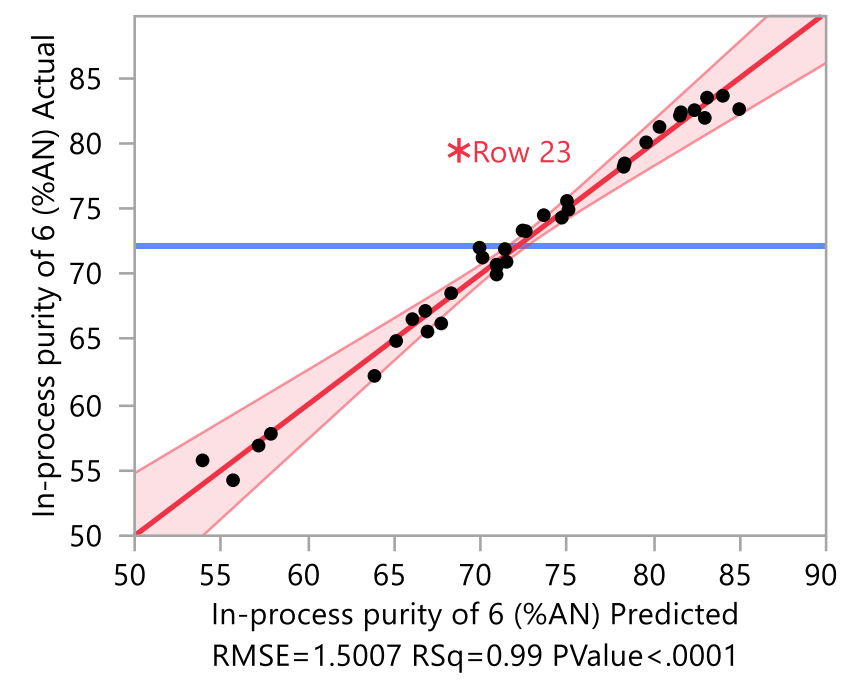

Summary of Fit for Model of End-of-Reaction Purity of Intermediate 6

$\begin{array}{lr}\text { RSquare } & 0.986707 \\ \text { RSquare Adj } & 0.967716 \\ \text { Root Mean Square Error } & 1.500686 \\ \text { Mean of Response } & 72.17571 \\ \text { Observations (or Sum Wgts) } & 35\end{array}$

Analysis of Variance for Model of End-of-Reaction Purity of Intermediate 6

\begin{tabular}{|c|c|c|c|c|}
\hline Source & DF & $\begin{array}{l}\text { Sum of } \\
\text { Squares }\end{array}$ & Mean Square & F Ratio \\
\hline Model & 20 & 2340.2634 & 117.013 & 51.9583 \\
\hline Error & 14 & 31.5288 & 2.252 & Prob $>$ F \\
\hline C. Total & 34 & 2371.7923 & & $<.0001$ * \\
\hline
\end{tabular}


Tables of effect tests of scaled estimates for all factors, quadratics, and interaction terms for the end-of-reaction purity of intermediate $\mathbf{6}$ are provided in Table $\mathbf{S 8}$ and Table S9, respectively. A plot of interaction profiles is shown in Figure S3.

\section{Table S8. $\quad$ Effect Tests for Model of End-of-Reaction Purity of Intermediate 6}

\begin{tabular}{|c|c|c|c|c|c|}
\hline Source & Nparm & DF & $\begin{array}{l}\text { Sum of } \\
\text { Squares }\end{array}$ & F Ratio & Prob $>$ F \\
\hline lodine (parts)(1.8,3.6) & 1 & 1 & 822.34205 & 365.1511 & $<.0001 *$ \\
\hline 5 (parts) $(0.6,1.1)$ & 1 & 1 & 272.53619 & 121.0164 & $<.0001 *$ \\
\hline Temperature $\left({ }^{\circ} \mathrm{C}\right)(5,35)$ & 1 & 1 & 135.87816 & 60.3351 & $<.0001 *$ \\
\hline lodine (parts)*lodine (parts) & 1 & 1 & 135.67240 & 60.2437 & $<.0001$ * \\
\hline Temperature $\left({ }^{\circ} \mathrm{C}\right)^{\star}$ Addition time of $4(\mathrm{~h})$ & 1 & 1 & 131.71669 & 58.4872 & $<.0001$ * \\
\hline Temperature $\left({ }^{\circ} \mathrm{C}\right)^{\star}$ Temperature $\left({ }^{\circ} \mathrm{C}\right)$ & 1 & 1 & 84.91386 & 37.7050 & $<.0001$ * \\
\hline 5 (parts)*Addition time of $4(h)$ & 1 & 1 & 48.61535 & 21.5871 & 0.0004 * \\
\hline lodine (parts) ${ }^{\star}$ Addition time of $4(\mathrm{~h})$ & 1 & 1 & 37.86143 & 16.8119 & 0.0011 * \\
\hline $\mathrm{CH} 2 \mathrm{Cl} 2$ (parts)*Addition time of $4(\mathrm{~h})$ & 1 & 1 & 28.19904 & 12.5214 & 0.0033 * \\
\hline Addition time of $4(h)(5,15)$ & 1 & 1 & 21.15063 & 9.3917 & $0.0084 *$ \\
\hline lodine (parts) ${ }^{\star}$ Temperature $\left({ }^{\circ} \mathrm{C}\right)$ & 1 & 1 & 14.72140 & 6.5369 & 0.0228 * \\
\hline 5 (parts) $\star 5$ (parts) & 1 & 1 & 14.26816 & 6.3356 & 0.0246 * \\
\hline $\mathrm{CH} 2 \mathrm{Cl} 2$ (parts) ${ }^{\star} \mathrm{CH} 2 \mathrm{Cl} 2$ (parts) & 1 & 1 & 14.21872 & 6.3137 & 0.0248 * \\
\hline Addition time of $4(h)^{\star}$ Addition time of $4(h)$ & 1 & 1 & 8.48620 & 3.7682 & 0.0726 \\
\hline $\mathrm{CH} 2 \mathrm{Cl} 2$ (parts) $(1.3,4.5)$ & 1 & 1 & 6.48550 & 2.8798 & 0.1118 \\
\hline 5 (parts) ${ }^{\star}$ Temperature $\left({ }^{\circ} \mathrm{C}\right)$ & 1 & 1 & 1.91553 & 0.8506 & 0.3720 \\
\hline $\mathrm{CH} 2 \mathrm{Cl} 2$ (parts) ${ }^{\star}$ Temperature $\left({ }^{\circ} \mathrm{C}\right)$ & 1 & 1 & 1.81302 & 0.8050 & 0.3848 \\
\hline 5 (parts) ${ }^{\star}$ lodine (parts) & 1 & 1 & 1.18906 & 0.5280 & 0.4794 \\
\hline 5 (parts) ${ }^{\star} \mathrm{CH} 2 \mathrm{Cl} 2$ (parts) & 1 & 1 & 0.89928 & 0.3993 & 0.5376 \\
\hline lodine (parts) ${ }^{*} \mathrm{CH} 2 \mathrm{Cl} 2$ (parts) & 1 & 1 & 0.48275 & 0.2144 & 0.6505 \\
\hline
\end{tabular}

Entries designated with an asterisk are statistically significant at the 95\% confidence interval. P values less than 0.05 but greater than 0.01 are shown in red text; $\mathrm{P}$ values less than 0.01 are shown in orange. 


\section{Table S9.}

\section{Scaled Estimates for Model of End-of-Reaction Purity of}

Intermediate 6

\begin{tabular}{|c|c|c|c|c|c|c|}
\hline Term & $\begin{array}{r}\text { Scaled } \\
\text { Estimate }\end{array}$ & & & Std Error & t Ratio & Prob $>|t|$ \\
\hline Intercept & 84.647588 & & & 1.286582 & 65.79 & $<.0001 *$ \\
\hline lodine (parts) $(1.8,3.6)$ & 5.8310656 & & & 0.305149 & 19.11 & $<.0001$ * \\
\hline 5 (parts) $(0.6,1.1)$ & 3.2988478 & & & 0.299875 & 11.00 & $<.0001$ * \\
\hline lodine (parts) ${ }^{\star}$ Addition time of $4(h)$ & 1.4110574 & & & 0.344141 & 4.10 & 0.0011 * \\
\hline $\mathrm{CH} 2 \mathrm{Cl} 2$ (parts) ${ }^{\star}$ Addition time of $4(\mathrm{~h})$ & 1.1251309 & & & 0.317962 & 3.54 & 0.0033 * \\
\hline lodine (parts) ${ }^{\star}$ Temperature $\left({ }^{\circ} \mathrm{C}\right)$ & 0.9123349 & & & 0.356837 & 2.56 & 0.0228 * \\
\hline 5 (parts) ${ }^{*}$ Temperature $\left({ }^{\circ} \mathrm{C}\right)$ & 0.3379366 & & & 0.366421 & 0.92 & 0.3720 \\
\hline $\mathrm{CH} 2 \mathrm{Cl} 2$ (parts) ${ }^{*}$ Temperature $\left({ }^{\circ} \mathrm{C}\right)$ & 0.3171162 & & & 0.353433 & 0.90 & 0.3848 \\
\hline 5 (parts)*lodine (parts) & 0.2440996 & & & 0.335935 & 0.73 & 0.4794 \\
\hline lodine (parts) ${ }^{\star} \mathrm{CH} 2 \mathrm{Cl} 2$ (parts) & 0.1496428 & & & 0.323209 & 0.46 & 0.6505 \\
\hline 5 (parts) ${ }^{\star} \mathrm{CH} 2 \mathrm{Cl} 2$ (parts) & -0.195766 & & & 0.309798 & -0.63 & 0.5376 \\
\hline $\mathrm{CH} 2 \mathrm{Cl} 2$ (parts) $(1.3,4.5)$ & -0.484932 & & & 0.285759 & -1.70 & 0.1118 \\
\hline Addition time of $4(h)(5,15)$ & -0.934388 & & & 0.304899 & -3.06 & 0.0084 * \\
\hline Addition time of $4(h)^{\star}$ Addition time of $4(h)$ & -1.378075 & & & 0.709915 & -1.94 & 0.0726 \\
\hline 5 (parts)*Addition time of $4(h)$ & -1.576523 & & & 0.339315 & -4.65 & 0.0004 * \\
\hline 5 (parts) $\star 5$ (parts) & -1.759443 & & & 0.699006 & -2.52 & 0.0246 * \\
\hline $\mathrm{CH} 2 \mathrm{Cl} 2$ (parts) ${ }^{*} \mathrm{CH} 2 \mathrm{Cl} 2$ (parts) & -1.89918 & & & 0.755833 & -2.51 & 0.0248 * \\
\hline Temperature $\left({ }^{\circ} \mathrm{C}\right)(5,35)$ & -2.516533 & & & 0.32398 & -7.77 & $<.0001$ * \\
\hline Temperature $\left({ }^{\circ} \mathrm{C}\right)^{\star}$ Addition time of $4(\mathrm{~h})$ & -2.689992 & & & 0.351739 & -7.65 & $<.0001$ * \\
\hline Temperature $\left({ }^{\circ} \mathrm{C}\right) *$ Temperature $\left({ }^{\circ} \mathrm{C}\right)$ & -4.778168 & & & 0.778148 & -6.14 & $<.0001$ * \\
\hline lodine (parts)* lodine (parts) & -5.797599 & & & 0.746951 & -7.76 & $<.0001$ * \\
\hline
\end{tabular}

Entries designated with an asterisk are statistically significant at the $95 \%$ confidence interval. $\mathrm{P}$ values less than 0.05 but greater than 0.01 are shown in red text; $P$ values less than 0.01 are shown in orange. 
Figure S3. Interaction Profiles for Model of End-of-Reaction Purity of Intermediate 6

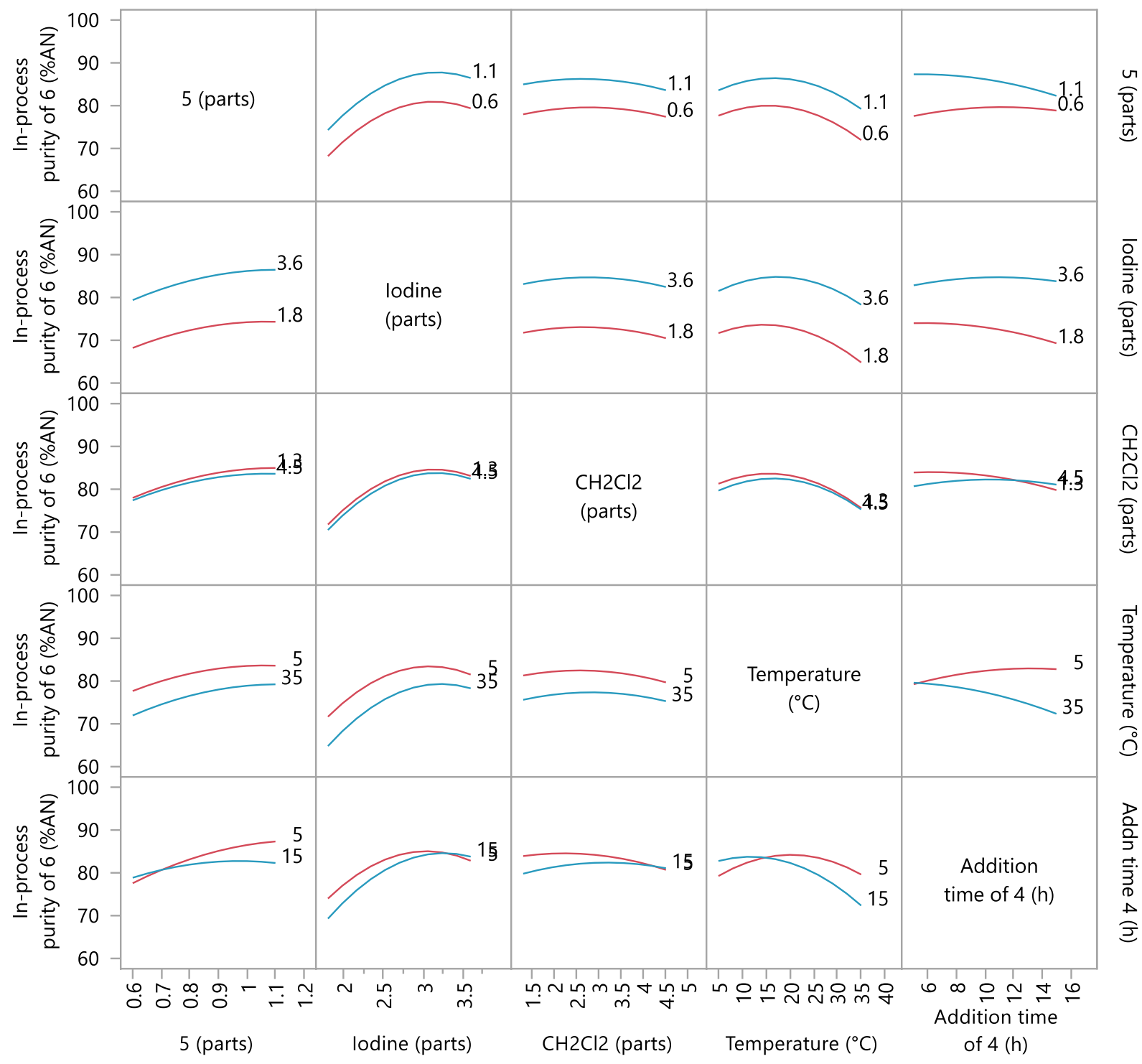




\section{Model of Post-Workup Assay Yield of Intermediate 6}

The distribution, quantiles, and summary statistics for the post-workup assay yield of $\mathbf{6}$ are illustrated in Figure S4.

\section{Figure S4. Distribution of Responses for Post-Workup Assay Yield of Intermediate 6}

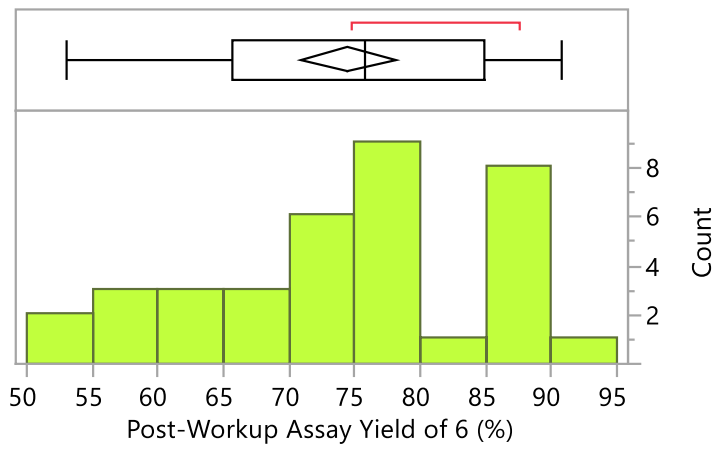

\begin{tabular}{|c|c|c|}
\hline \multicolumn{3}{|c|}{ Quantiles } \\
\hline $100.0 \%$ & maximum & 90.7 \\
\hline $99.5 \%$ & & 90.7 \\
\hline $97.5 \%$ & & 90.7 \\
\hline $90.0 \%$ & & 87.63 \\
\hline $75.0 \%$ & quartile & 84.9 \\
\hline $50.0 \%$ & median & 75.85 \\
\hline $25.0 \%$ & quartile & 65.725 \\
\hline $10.0 \%$ & & 56.52 \\
\hline $2.5 \%$ & & 53.1 \\
\hline $0.5 \%$ & & 53.1 \\
\hline $0.0 \%$ & minimum & 53.1 \\
\hline
\end{tabular}

\begin{tabular}{lr}
\hline \multicolumn{2}{|l|}{ Summary Statistics } \\
\hline Mean & 74.463889 \\
Std Dev & 10.738533 \\
Std Err Mean & 1.7897555 \\
Upper 95\% Mean & 78.097286 \\
Lower 95\% Mean & 70.830492 \\
N & 36 \\
Sum & 2680.7 \\
Variance & 115.31609 \\
CV & 14.421128 \\
N Missing & 0 \\
\end{tabular}

A standard least squares regression was performed on the augmented dataset. The model generated was statistically significant with high $\mathrm{R}^{2}$ and $\mathrm{R}^{2}$ adj values, but analysis of the studentized residuals revealed experiment 23 to be an outlier at the $99 \%$ confidence interval. A new model excluding experiment 23 was constructed for which the actual-by-predicted plot is shown in Figure S5. Further statistical details of the model, including summary of fit and analysis of variance, are provided in Table S10 and Table S11, respectively.

Figure S5.

\section{Actual-by-Predicted Plot for Model of Post-Workup Assay Yield of Intermediate 6}

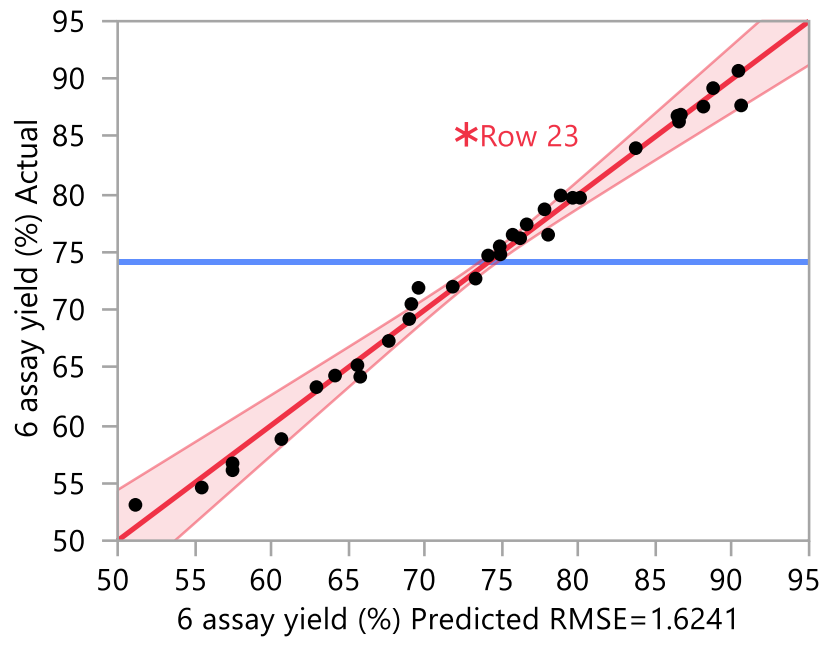

$\mathrm{RSq}=0.99$ PValue $<.0001$ 


\section{Table S10. Summary of Fit for Model of Post-Workup Assay Yield of Intermediate 6}

$\begin{array}{lr}\text { RSquare } & 0.990574 \\ \text { RSquare Adj } & 0.977108 \\ \text { Root Mean Square Error } & 1.624079 \\ \text { Mean of Response } & 74.15714 \\ \text { Observations (or Sum Wgts) } & 35\end{array}$

Table S11.

\section{Analysis of Variance for Model of Post-Workup Assay Yield of Intermediate 6}

\begin{tabular}{|l|r|r|r|r|} 
Source & DF & $\begin{array}{r}\text { Sum of } \\
\text { Squares }\end{array}$ & Mean Square & F Ratio \\
\hline Model & 20 & 3880.5788 & 194.029 & 73.5618 \\
Error & 14 & 36.9269 & 2.638 & Prob > F \\
C. Total & 34 & 3917.5057 & & $<.0001$ *
\end{tabular}

Tables of effect tests of scaled estimates for all factors, quadratics, and interaction terms for the assay yield of intermediate 6 are provided in Table S12 and Table S13, respectively. A plot of interaction profiles is shown in Figure S6.

Table S12. $\quad$ Effect Tests for Model of Post-Workup Assay Yield of Intermediate 6

\begin{tabular}{|c|c|c|c|c|c|}
\hline Source & Nparm & DF & $\begin{array}{l}\text { Sum of } \\
\text { Squares }\end{array}$ & F Ratio & Prob $>$ F \\
\hline lodine (parts) $(1.8,3.6)$ & 1 & 1 & 1402.5923 & 531.7617 & $<.0001$ * \\
\hline 5 (parts) $(0.6,1.1)$ & 1 & 1 & 719.8390 & 272.9109 & $<.0001 *$ \\
\hline lodine (parts)*lodine (parts) & 1 & 1 & 212.2906 & 80.4853 & $<.0001$ * \\
\hline Temperature $\left({ }^{\circ} \mathrm{C}\right) \star 4$ addition time $(\mathrm{h})$ & 1 & 1 & 198.2989 & 75.1806 & $<.0001$ * \\
\hline Temperature $\left({ }^{\circ} \mathrm{C}\right)^{\star}$ Temperature $\left({ }^{\circ} \mathrm{C}\right)$ & 1 & 1 & 98.1584 & 37.2146 & $<.0001$ * \\
\hline Temperature $\left({ }^{\circ} \mathrm{C}\right)(5,35)$ & 1 & 1 & 96.4602 & 36.5707 & $<.0001 *$ \\
\hline 5 (parts) ${ }^{\star} 4$ addition time $(\mathrm{h})$ & 1 & 1 & 62.5558 & 23.7166 & 0.0002 * \\
\hline lodine $(\text { parts })^{*}$ Temperature $\left({ }^{\circ} \mathrm{C}\right)$ & 1 & 1 & 44.4131 & 16.8383 & 0.0011 * \\
\hline $\mathrm{CH} 2 \mathrm{Cl} 2$ (parts) $(1.3,4.5)$ & 1 & 1 & 40.8285 & 15.4792 & 0.0015 * \\
\hline $\mathrm{CH} 2 \mathrm{Cl} 2$ (parts)*4 addition time $(\mathrm{h})$ & 1 & 1 & 30.3088 & 11.4909 & 0.0044 * \\
\hline lodine (parts) $* 4$ addition time $(\mathrm{h})$ & 1 & 1 & 21.5241 & 8.1604 & 0.0127 * \\
\hline $\mathrm{CH} 2 \mathrm{Cl} 2$ (parts) ${ }^{*} \mathrm{CH} 2 \mathrm{Cl} 2$ (parts) & 1 & 1 & 18.6719 & 7.0790 & 0.0186 * \\
\hline 4 addition time $(h) \star 4$ addition time $(h)$ & 1 & 1 & 15.3427 & 5.8168 & 0.0302 * \\
\hline 4 addition time $(h)(5,15)$ & 1 & 1 & 11.6796 & 4.4280 & 0.0539 \\
\hline 5 (parts) ${ }^{\star}$ lodine (parts) & 1 & 1 & 3.3823 & 1.2823 & 0.2765 \\
\hline 5 (parts) 5 (parts) & 1 & 1 & 3.2207 & 1.2211 & 0.2878 \\
\hline lodine (parts) ${ }^{*} \mathrm{CH} 2 \mathrm{Cl} 2$ (parts) & 1 & 1 & 1.9564 & 0.7417 & 0.4036 \\
\hline $\mathrm{CH} 2 \mathrm{Cl} 2$ (parts) ${ }^{*}$ Temperature $\left({ }^{\circ} \mathrm{C}\right.$ ) & 1 & 1 & 0.6651 & 0.2522 & 0.6234 \\
\hline 5 (parts) ${ }^{\star} \mathrm{CH} 2 \mathrm{Cl} 2$ (parts) & 1 & 1 & 0.4857 & 0.1841 & 0.6744 \\
\hline 5 (parts) ${ }^{*}$ Temperature $\left({ }^{\circ} \mathrm{C}\right)$ & 1 & 1 & 0.3424 & 0.1298 & 0.7240 \\
\hline
\end{tabular}

Entries designated with an asterisk are statistically significant at the $95 \%$ confidence interval. P values less than 0.05 but greater than 0.01 are shown in red text; $\mathrm{P}$ values less than 0.01 are shown in orange. 
Table S13. $\quad$ Scaled Estimates for Model of Post-Workup Assay Yield of Intermediate 6

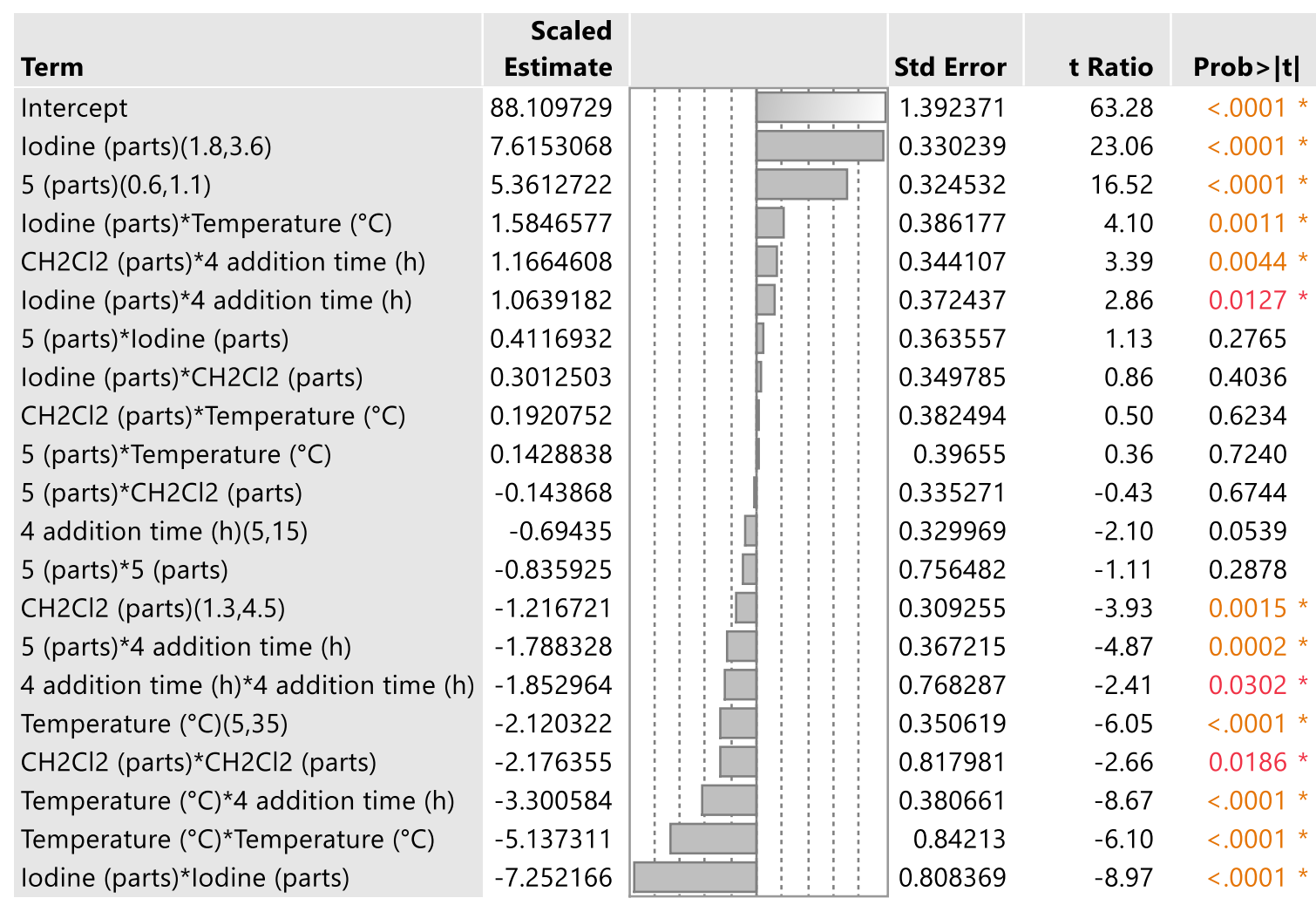

Entries designated with an asterisk are statistically significant at the $95 \%$ confidence interval. $\mathrm{P}$ values less than 0.05 but greater than 0.01 are shown in red text; $P$ values less than 0.01 are shown in orange. 
Figure S6. Interaction Profiles for Model of Post-Workup Assay Yield of Intermediate 6

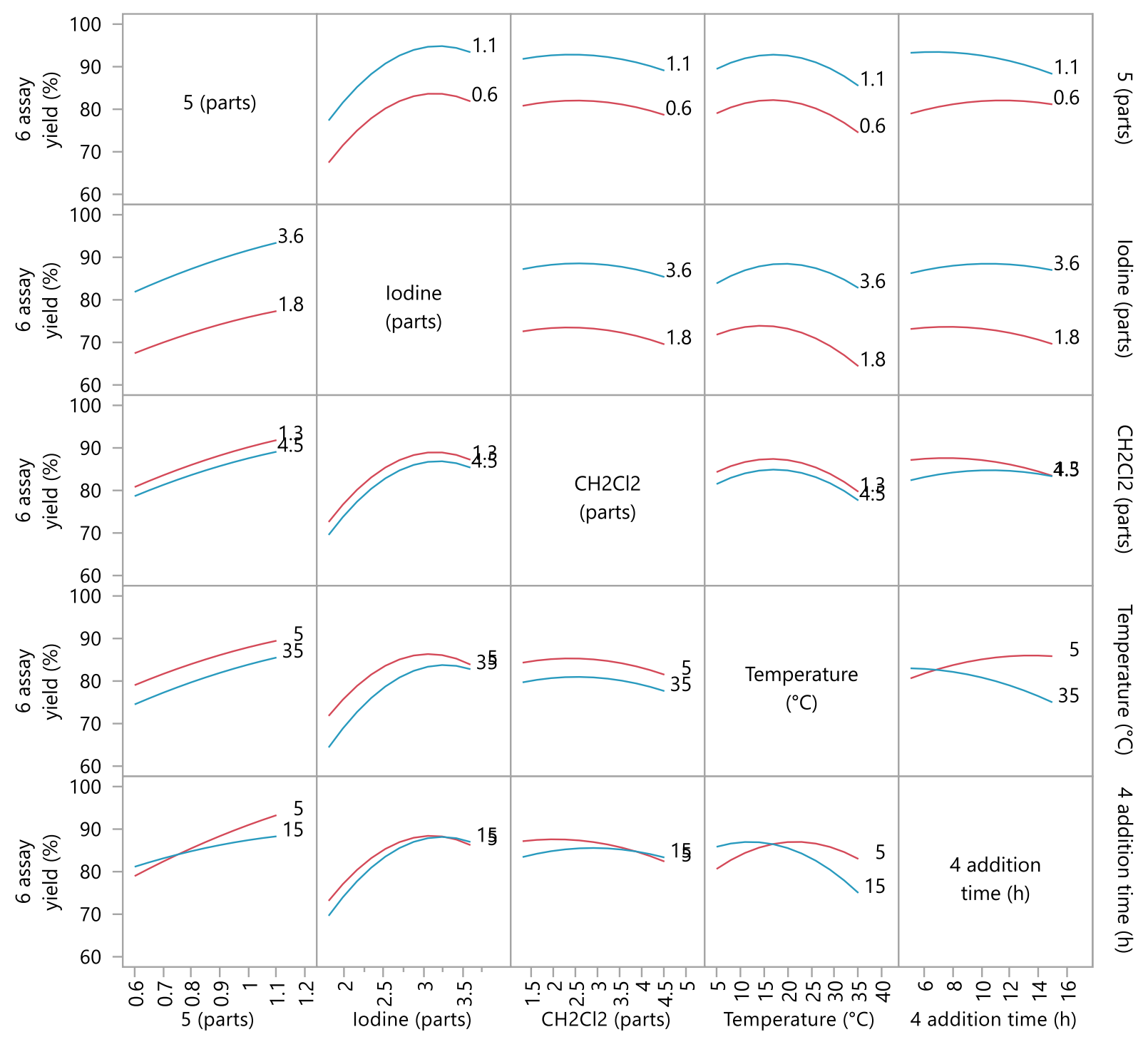




\section{Model of End-of-Reaction Level of Impurity 9}

The distribution, quantiles, and summary statistics for the end-of-reaction level of impurity 9 are illustrated in Figure S7.

Figure S7. Distribution of Responses for End-of-Reaction Level of Impurity 9

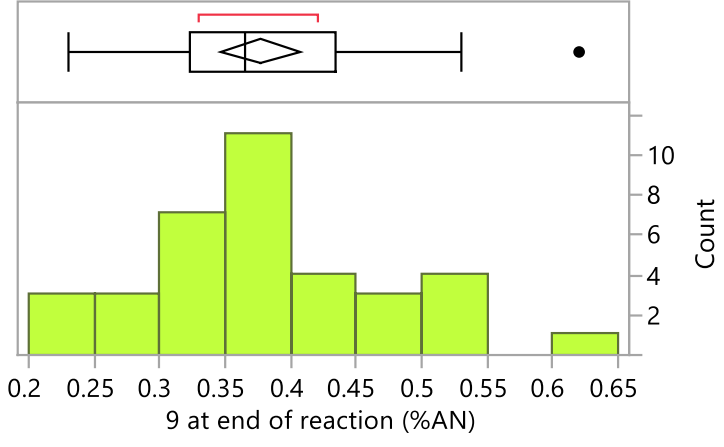

\begin{tabular}{|c|c|c|}
\hline \multicolumn{3}{|c|}{ Quantiles } \\
\hline $100.0 \%$ & maximum & 0.62 \\
\hline $99.5 \%$ & & 0.62 \\
\hline $97.5 \%$ & & 0.62 \\
\hline $90.0 \%$ & & 0.516 \\
\hline $75.0 \%$ & quartile & 0.435 \\
\hline $50.0 \%$ & median & 0.365 \\
\hline $25.0 \%$ & quartile & 0.3225 \\
\hline $10.0 \%$ & & 0.247 \\
\hline $2.5 \%$ & & 0.23 \\
\hline $0.5 \%$ & & 0.23 \\
\hline $0.0 \%$ & minimum & 0.23 \\
\hline
\end{tabular}

\begin{tabular}{l|r|}
\hline \multicolumn{2}{l}{ Summary Statistics } \\
\hline Mean & 0.3772222 \\
Std Dev & 0.0914209 \\
Std Err Mean & 0.0152368 \\
Upper 95\% Mean & 0.4081546 \\
Lower 95\% Mean & 0.3462898 \\
N & 36 \\
Sum & 13.58 \\
Variance & 0.0083578 \\
CV & 24.235286 \\
N Missing & 0
\end{tabular}

A standard least squares regression was performed on the augmented dataset. The model generated was statistically significant with high $\mathrm{R}^{2}$ and $\mathrm{R}^{2}$ adj values, and analysis of the studentized residuals revealed no outliers at the $99 \%$ confidence interval. The actual-by-predicted plot is shown in Figure S8. Further statistical details of the model, including summary of fit and analysis of variance are provided in Table S14 and Table S15, respectively.

Figure S8. Actual-by-Predicted Plot for Model of End-of-Reaction Level of
Impurity 9

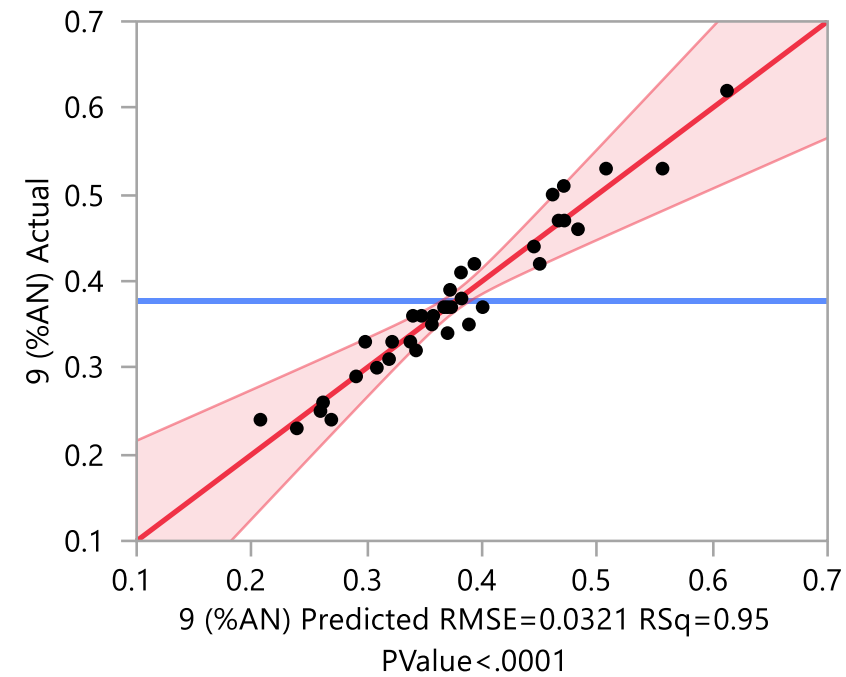


Table S14.

Table S15.

Summary of Fit for Model of End-of-Reaction Level of Impurity 9

$\begin{array}{lr}\text { RSquare } & 0.947251 \\ \text { RSquare Adj } & 0.876919 \\ \text { Root Mean Square Error } & 0.032073 \\ \text { Mean of Response } & 0.377222 \\ \text { Observations (or Sum Wgts) } & 36\end{array}$

\section{Analysis of Variance for Model of End-of-Reaction Level of Impurity 9}

\begin{tabular}{|l|r|r|r|r|}
\hline Source & DF & $\begin{array}{r}\text { Sum of } \\
\text { Squares }\end{array}$ & Mean Square & F Ratio \\
\hline Model & 20 & 0.27709200 & 0.013855 & 13.4683 \\
Error & 15 & 0.01543022 & 0.001029 & Prob > F \\
C. Total & 35 & 0.29252222 & & $<.0001$ *
\end{tabular}

Tables of effect tests of scaled estimates for all factors, quadratics, and interaction terms for the end-of-reaction level of impurity 9 are provided in Table S16 and Table S17, respectively. A plot of interaction profiles is shown in Figure S9.

Table S16.

Effect Tests for Model of End-of-Reaction Level of Impurity 9

\begin{tabular}{|c|}
\hline Source \\
\hline 5 (parts) $(0.6,1.1)$ \\
\hline $\mathrm{CH} 2 \mathrm{Cl} 2$ (parts) $(1.3,4.5)$ \\
\hline Temperature $\left({ }^{\circ} \mathrm{C}\right)(5,35)$ \\
\hline Temperature $\left({ }^{\circ} \mathrm{C}\right)^{\star} 4$ addition time $(h)$ \\
\hline 4 addition time $(h)(5,15)$ \\
\hline 5 (parts) $* 4$ addition time $(\mathrm{h})$ \\
\hline 5 (parts) ${ }^{\star} \mathrm{CH} 2 \mathrm{Cl} 2$ (parts) \\
\hline $\mathrm{CH} 2 \mathrm{Cl} 2$ (parts) $* 4$ addition time $(\mathrm{h})$ \\
\hline lodine (parts)* lodine (parts) \\
\hline Temperature $\left({ }^{\circ} \mathrm{C}\right){ }^{*}$ Temperature $\left({ }^{\circ} \mathrm{C}\right)$ \\
\hline 5 (parts)* Temperature $\left({ }^{\circ} \mathrm{C}\right)$ \\
\hline 5 (parts) ${ }^{\star}$ lodine (parts) \\
\hline lodine (parts) $(1.8,3.6)$ \\
\hline 4 addition time $(h)^{*} 4$ addition time $(h)$ \\
\hline lodine (parts) ${ }^{\star} \mathrm{CH} 2 \mathrm{Cl} 2$ (parts) \\
\hline $\mathrm{CH} 2 \mathrm{Cl} 2$ (parts) ${ }^{*}$ Temperature $\left({ }^{\circ} \mathrm{C}\right)$ \\
\hline 5 (parts) $* 5$ (parts) \\
\hline lodine (parts) ${ }^{\star}$ Temperature $\left({ }^{\circ} \mathrm{C}\right)$ \\
\hline $\mathrm{CH} 2 \mathrm{Cl} 2$ (parts) ${ }^{\star} \mathrm{CH} 2 \mathrm{Cl} 2$ (parts) \\
\hline lodine (parts) ${ }^{*} 4$ addition time $(h)$ \\
\hline
\end{tabular}

\begin{tabular}{|rr|r|r|r|}
\hline Nparm & DF & $\begin{array}{r}\text { Sum of } \\
\text { Squares }\end{array}$ & F Ratio & Prob > F \\
\hline 1 & 1 & 0.15120287 & 146.9870 & $<.0001$ * \\
1 & 1 & 0.05697667 & 55.3881 & $<.0001$ * \\
1 & 1 & 0.02811817 & 27.3342 & 0.0001 * \\
1 & 1 & 0.01188247 & 11.5512 & 0.0040 * \\
1 & 1 & 0.00849682 & 8.2599 & 0.0116 * \\
1 & 1 & 0.00830499 & 8.0734 & 0.0124 * \\
1 & 1 & 0.00745495 & 7.2471 & 0.0167 * \\
1 & 1 & 0.00356959 & 3.4701 & 0.0822 \\
1 & 1 & 0.00300189 & 2.9182 & 0.1082 \\
1 & 1 & 0.00107046 & 1.0406 & 0.3239 \\
1 & 1 & 0.00089065 & 0.8658 & 0.3668 \\
1 & 1 & 0.00088577 & 0.8611 & 0.3681 \\
1 & 1 & 0.00071026 & 0.6905 & 0.4190 \\
1 & 1 & 0.00063898 & 0.6212 & 0.4429 \\
1 & 1 & 0.00054974 & 0.5344 & 0.4760 \\
1 & 1 & 0.00042729 & 0.4154 & 0.5290 \\
1 & 1 & 0.00039347 & 0.3825 & 0.5455 \\
1 & 1 & 0.00039289 & 0.3819 & 0.5458 \\
1 & 1 & 0.00022942 & 0.2230 & 0.6435 \\
1 & 1 & 0.00004350 & 0.0423 & 0.8398
\end{tabular}

Entries designated with an asterisk are statistically significant at the $95 \%$ confidence interval. P values less than 0.05 but greater than 0.01 are shown in red text; $\mathrm{P}$ values less than 0.01 are shown in orange. 
Table S17. $\quad$ Scaled Estimates for Model of End-of-Reaction Level of Impurity 9

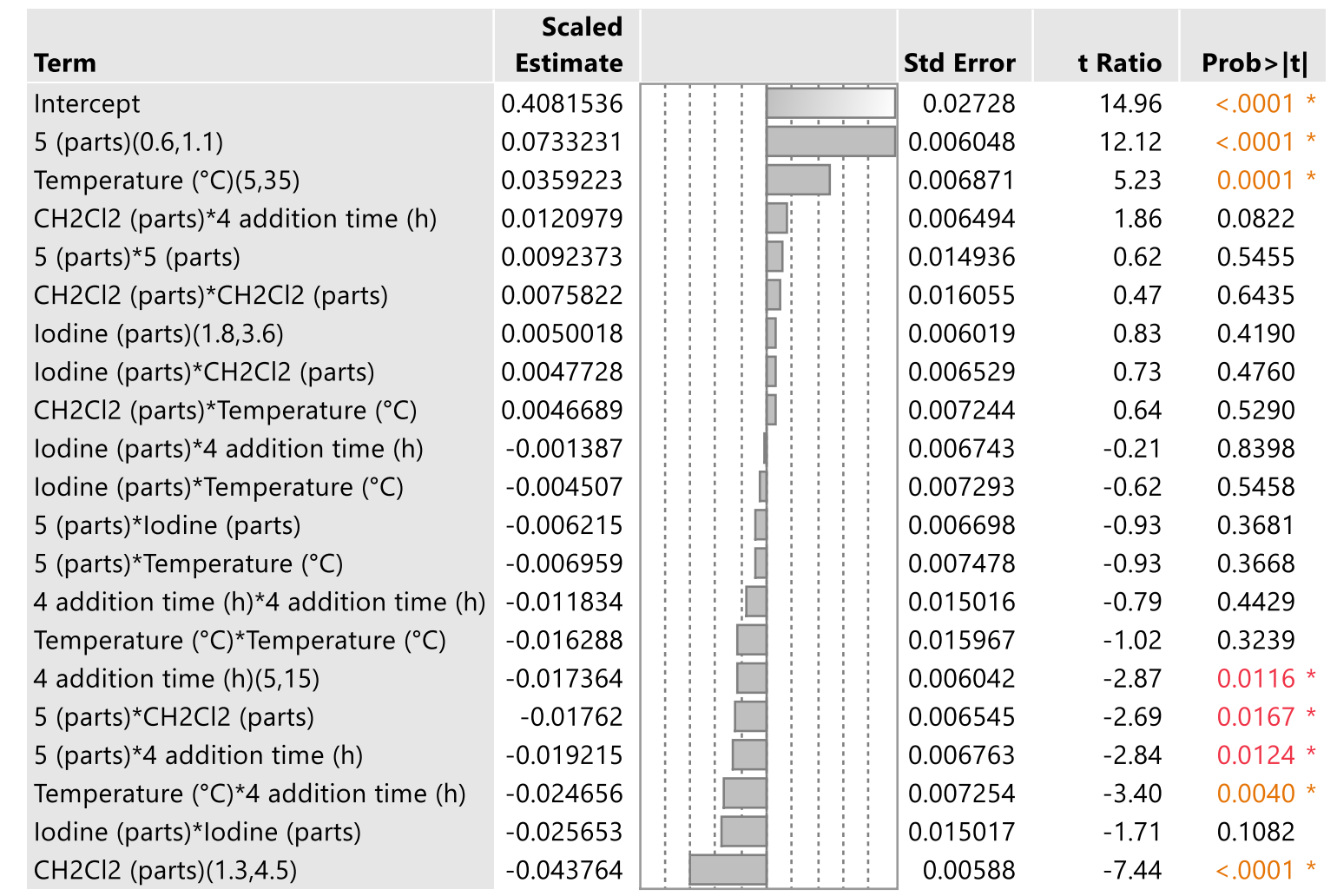

Entries designated with an asterisk are statistically significant at the $95 \%$ confidence interval. P values less than 0.05 but greater than 0.01 are shown in red text; $P$ values less than 0.01 are shown in orange. 
Figure S9. Interaction Profiles for Model of End-of-Reaction Level of Impurity 9

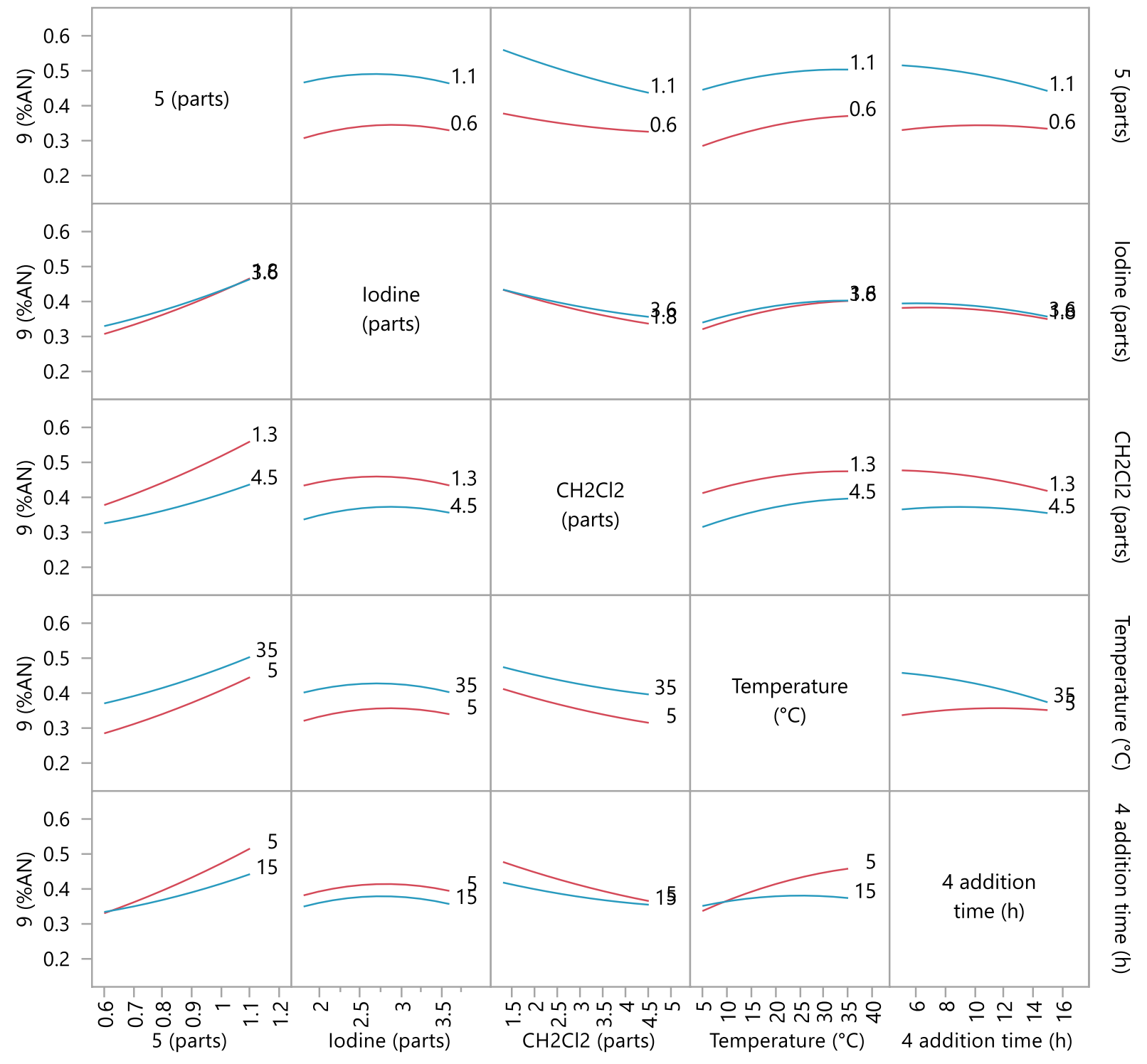




\section{Model of End-of-Reaction Level of Impurity 12}

The distribution, quantiles, and summary statistics for the end-of-reaction level of impurity $\mathbf{1 2}$ are illustrated in Figure S10.

Figure S10. $\quad$ Distribution of Responses for End-of-Reaction Level of Impurity 12

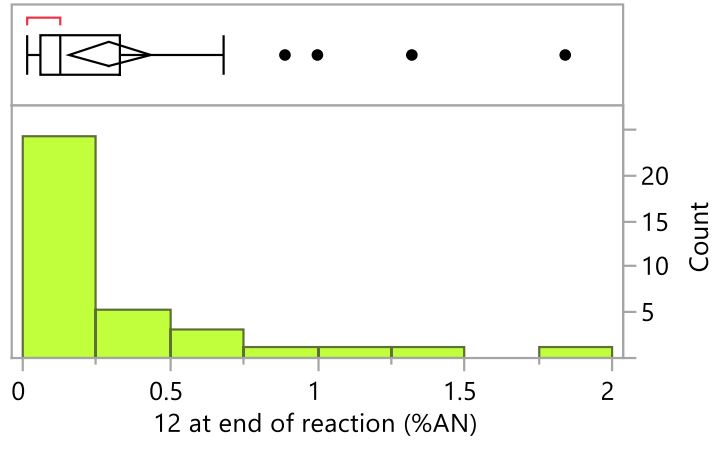

\begin{tabular}{|c|c|c|}
\hline \multicolumn{3}{|c|}{ Quantiles } \\
\hline $100.0 \%$ & maximum & 1.84 \\
\hline $99.5 \%$ & & 1.84 \\
\hline $97.5 \%$ & & 1.84 \\
\hline $90.0 \%$ & & 0.923 \\
\hline $75.0 \%$ & quartile & 0.3325 \\
\hline $50.0 \%$ & median & 0.13 \\
\hline $25.0 \%$ & quartile & 0.06 \\
\hline $10.0 \%$ & & 0.03 \\
\hline $2.5 \%$ & & 0.02 \\
\hline $0.5 \%$ & & 0.02 \\
\hline $0.0 \%$ & minimum & 0.02 \\
\hline
\end{tabular}

Summary Statistics

Mean $\quad 0.2961111$

Std Dev $\quad 0.4014138$

Std Err Mean $\quad 0.0669023$

Upper 95\% Mean 0.43193

Lower 95\% Mean 0.1602922

$\mathrm{N} \quad 36$

Sum $\quad 10.66$

Variance $\quad 0.161133$

CV $\quad 135.56187$

N Missing $\quad 0$

A standard least squares regression was performed on the augmented dataset. The model generated was statistically significant with high $\mathrm{R}^{2}$ and $\mathrm{R}^{2}$ adj values, but analysis of the studentized residuals revealed experiments 7 and 23 to be outliers at the $99 \%$ confidence interval. A new model excluding experiments 7 and 23 was constructed for which the actual-by-predicted plot is shown in Figure S11. Further statistical details of the model, including summary of fit and analysis of variance are provided in Table S18 and Table S19, respectively.

Figure S11.

Actual-by-Predicted Plot for Model of End-of-Reaction Level of Impurity 12

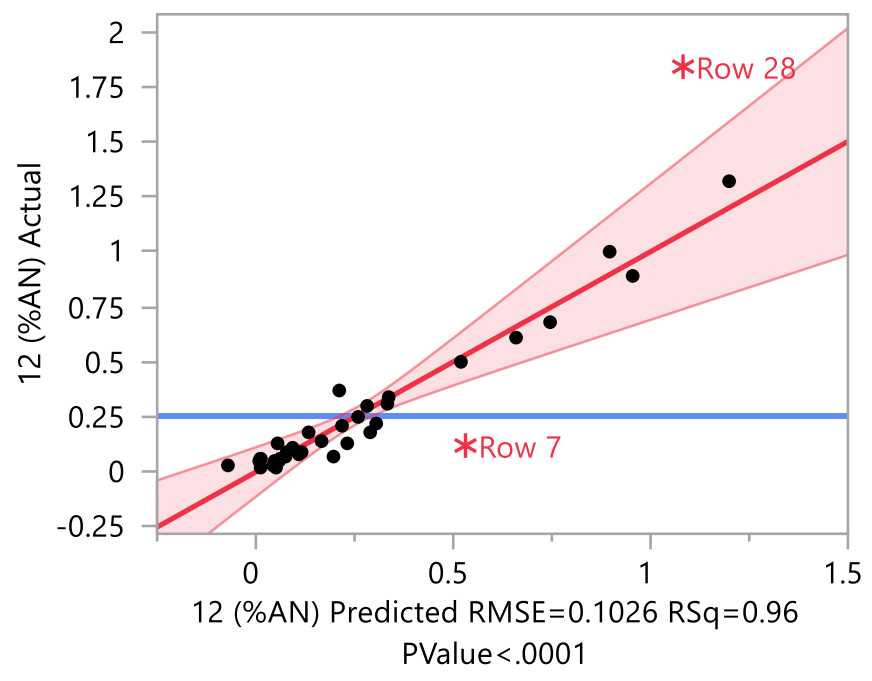


Table S18.

Table S19.
Summary of Fit for Model of End-of-Reaction Level of Impurity 12

$\begin{array}{lr}\text { RSquare } & 0.95687 \\ \text { RSquare Adj } & 0.890517 \\ \text { Root Mean Square Error } & 0.102553 \\ \text { Mean of Response } & 0.255882 \\ \text { Observations (or Sum Wgts) } & 34\end{array}$

\section{Analysis of Variance for Model of End-of-Reaction Level of Impurity 12}

\begin{tabular}{l|r|r|r|r|}
\hline Source & DF & $\begin{array}{r}\text { Sum of } \\
\text { Squares }\end{array}$ & Mean Square & F Ratio \\
\hline Model & 20 & 3.0333009 & 0.151665 & 14.4208 \\
Error & 13 & 0.1367227 & 0.010517 & Prob > F \\
C. Total & 33 & 3.1700235 & & $<.0001$ *
\end{tabular}

Tables of effect tests of scaled estimates for all factors, quadratics, and interaction terms for the end-of-reaction level of impurity $\mathbf{1 2}$ are provided in Table S20 and Table S21, respectively. A plot of interaction profiles is shown in Figure S12.

Table S20.

Effect Tests for Model of End-of-Reaction Level of Impurity 12

\begin{tabular}{|c|}
\hline Source \\
\hline Temperature $\left({ }^{\circ} \mathrm{C}\right)(5,35)$ \\
\hline lodine (parts) ${ }^{*}$ Temperature $\left({ }^{\circ} \mathrm{C}\right)$ \\
\hline lodine (parts) $(1.8,3.6)$ \\
\hline Temperature $\left({ }^{\circ} \mathrm{C}\right) * 4$ addition time $(h)$ \\
\hline 4 addition time $(h)(5,15)$ \\
\hline lodine (parts) ${ }^{\star} 4$ addition time $(h)$ \\
\hline 5 (parts)*lodine (parts) \\
\hline 5 (parts) ${ }^{\star} \mathrm{CH} 2 \mathrm{Cl} 2$ (parts) \\
\hline Temperature $\left({ }^{\circ} \mathrm{C}\right)^{*}$ Temperature $\left({ }^{\circ} \mathrm{C}\right)$ \\
\hline lodine (parts) ${ }^{\star}$ lodine (parts) \\
\hline 5 (parts) ${ }^{\star} 4$ addition time $(h)$ \\
\hline lodine (parts) ${ }^{\star} \mathrm{CH} 2 \mathrm{Cl} 2$ (parts) \\
\hline $\mathrm{CH} 2 \mathrm{Cl} 2$ (parts) $* 4$ addition time $(\mathrm{h})$ \\
\hline 5 (parts) $* 5$ (parts) \\
\hline 4 addition time $(h)^{*} 4$ addition time $(h)$ \\
\hline 5 (parts) ${ }^{\star}$ Temperature $\left({ }^{\circ} \mathrm{C}\right)$ \\
\hline $\mathrm{CH} 2 \mathrm{Cl} 2$ (parts)* Temperature $\left({ }^{\circ} \mathrm{C}\right.$ ) \\
\hline $\mathrm{CH} 2 \mathrm{Cl} 2$ (parts) ${ }^{*} \mathrm{CH} 2 \mathrm{Cl} 2$ (parts) \\
\hline $\mathrm{CH} 2 \mathrm{Cl} 2$ (parts) $(1.3,4.5)$ \\
\hline 5 (parts) $(0.6,1.1)$ \\
\hline
\end{tabular}

\begin{tabular}{|rr|r|r|r|} 
Nparm & DF & $\begin{array}{r}\text { Sum of } \\
\text { Squares }\end{array}$ & F Ratio & Prob > F \\
1 & 1 & 1.0787895 & 102.5745 & $<.0001$ * \\
1 & 1 & 0.5680563 & 54.0125 & $<.0001$ * \\
1 & 1 & 0.4125709 & 39.2285 & $<.0001$ * \\
1 & 1 & 0.2432652 & 23.1304 & 0.0003 * \\
1 & 1 & 0.1130627 & 10.7503 & 0.0060 * \\
1 & 1 & 0.0814404 & 7.7436 & 0.0155 * \\
1 & 1 & 0.0466614 & 4.4367 & 0.0552 \\
1 & 1 & 0.0343121 & 3.2625 & 0.0941 \\
1 & 1 & 0.0229646 & 2.1835 & 0.1633 \\
1 & 1 & 0.0102614 & 0.9757 & 0.3413 \\
1 & 1 & 0.0097824 & 0.9301 & 0.3524 \\
1 & 1 & 0.0069173 & 0.6577 & 0.4320 \\
1 & 1 & 0.0050953 & 0.4845 & 0.4987 \\
1 & 1 & 0.0042858 & 0.4075 & 0.5343 \\
1 & 1 & 0.0038838 & 0.3693 & 0.5539 \\
1 & 1 & 0.0032159 & 0.3058 & 0.5897 \\
1 & 1 & 0.0028612 & 0.2721 & 0.6107 \\
1 & 1 & 0.0010839 & 0.1031 & 0.7533 \\
1 & 1 & 0.0007133 & 0.0678 & 0.7986 \\
1 & 1 & 0.0000264 & 0.0025 & 0.9608
\end{tabular}

Entries designated with an asterisk are statistically significant at the $95 \%$ confidence interval. P values less than 0.05 but greater than 0.01 are shown in red text; $\mathrm{P}$ values less than 0.01 are shown in orange. 
Table S21. $\quad$ Scaled Estimates for Model of End-of-Reaction Level of Impurity 12

\begin{tabular}{|c|c|c|c|c|}
\hline Term & $\begin{array}{r}\text { Scaled } \\
\text { Estimate }\end{array}$ & Std Error & t Ratio & Prob $>|\mathbf{t}|$ \\
\hline Temperature $\left({ }^{\circ} \mathrm{C}\right)(5,35)$ & 0.2309113 & 0.0228 & 10.13 & $<.0001$ * \\
\hline Intercept & 0.1932283 & 0.110373 & 1.75 & 0.1035 \\
\hline Temperature $\left({ }^{\circ} \mathrm{C}\right) \star 4$ addition time $(\mathrm{h})$ & 0.1153657 & 0.023988 & 4.81 & 0.0003 * \\
\hline Temperature $\left({ }^{\circ} \mathrm{C}\right)^{\star}$ Temperature $\left({ }^{\circ} \mathrm{C}\right)$ & 0.087721 & 0.059364 & 1.48 & 0.1633 \\
\hline 4 addition time $(h)(5,15)$ & 0.0669027 & 0.020405 & 3.28 & 0.0060 * \\
\hline lodine (parts)*lodine (parts) & 0.0484701 & 0.04907 & 0.99 & 0.3413 \\
\hline 5 (parts) ${ }^{\star} \mathrm{CH} 2 \mathrm{Cl} 2$ (parts) & 0.0380011 & 0.021039 & 1.81 & 0.0941 \\
\hline 5 (parts) $\star 5$ (parts) & 0.0346229 & 0.054237 & 0.64 & 0.5343 \\
\hline 5 (parts) ${ }^{*} 4$ addition time $(\mathrm{h})$ & 0.0214491 & 0.02224 & 0.96 & 0.3524 \\
\hline lodine (parts) ${ }^{\star} \mathrm{CH} 2 \mathrm{Cl} 2$ (parts) & 0.0178266 & 0.021981 & 0.81 & 0.4320 \\
\hline $\mathrm{CH} 2 \mathrm{Cl} 2$ (parts) $* 4$ addition time (h) & 0.0154005 & 0.022126 & 0.70 & 0.4987 \\
\hline 5 (parts) ${ }^{*}$ Temperature $\left({ }^{\circ} \mathrm{C}\right)$ & 0.0135716 & 0.024543 & 0.55 & 0.5897 \\
\hline 5 (parts) $(0.6,1.1)$ & 0.0010501 & 0.020972 & 0.05 & 0.9608 \\
\hline $\mathrm{CH} 2 \mathrm{Cl} 2$ (parts) $(1.3,4.5)$ & -0.00513 & 0.019697 & -0.26 & 0.7986 \\
\hline $\mathrm{CH} 2 \mathrm{Cl} 2$ (parts) ${ }^{*}$ Temperature $\left({ }^{\circ} \mathrm{C}\right)$ & -0.012531 & 0.024024 & -0.52 & 0.6107 \\
\hline $\mathrm{CH} 2 \mathrm{Cl} 2$ (parts)* $\mathrm{CH} 2 \mathrm{Cl} 2$ (parts) & -0.020452 & 0.063707 & -0.32 & 0.7533 \\
\hline 4 addition time $(h) * 4$ addition time $(h)$ & -0.034553 & 0.056859 & -0.61 & 0.5539 \\
\hline 5 (parts) ${ }^{\star}$ lodine (parts) & -0.048091 & 0.022831 & -2.11 & 0.0552 \\
\hline lodine (parts) ${ }^{\star} 4$ addition time $(\mathrm{h})$ & -0.063635 & 0.022868 & -2.78 & 0.0155 * \\
\hline lodine (parts) $(1.8,3.6)$ & -0.132767 & 0.021198 & -6.26 & $<.0001$ * \\
\hline lodine (parts) ${ }^{\star}$ Temperature $\left({ }^{\circ} \mathrm{C}\right)$ & -0.17834 & 0.024266 & -7.35 & $<.0001$ \\
\hline
\end{tabular}

Entries designated with an asterisk are statistically significant at the $95 \%$ confidence interval. P values less than 0.05 but greater than 0.01 are shown in red text; $\mathrm{P}$ values less than 0.01 are shown in orange. 
Figure S12.

Interaction Profiles for Model of End-of-Reaction Level of Impurity 12

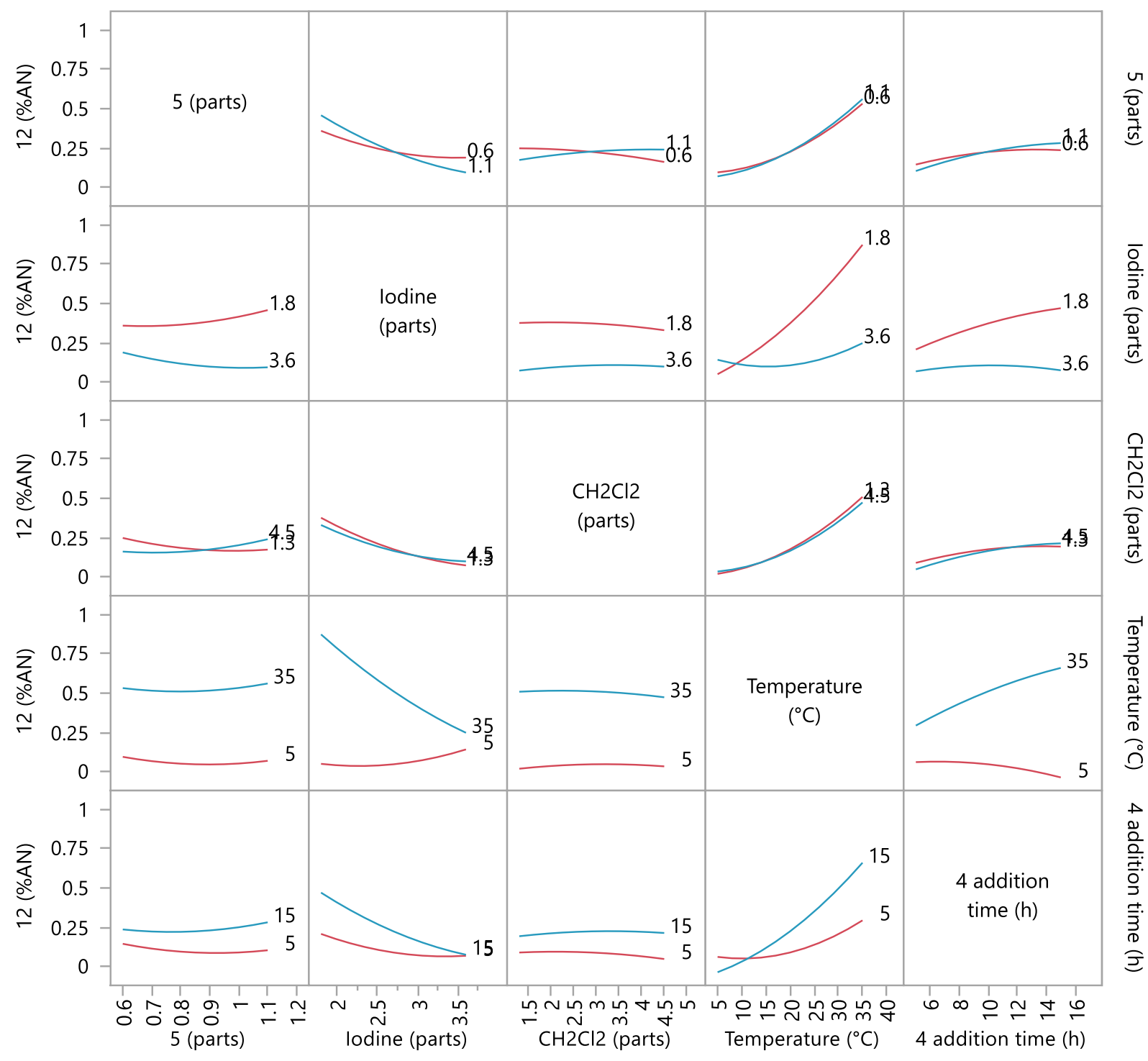




\section{Comparison of Iodoetherification Reaction Performance Before and After DOE}

To further characterize the iodoetherification reaction following the DOE, a series of studies was run to evaluate the sensitivity of the reaction outcome as a function of the key parameters reaction temperature and addition time of $\mathbf{4}$ (Table S22). As anticipated from the models, these experiments demonstrated less favorable outcomes at shorter addition times, but little sensitivity to the outcome as the addition time was lengthened beyond the intended time of $15 \mathrm{~h}$.

Table S22.

Iodoetherification Reaction DOE Validation Trials

\begin{tabular}{|c|c|c|c|c|c|c|c|c|c|}
\hline \multirow{2}{*}{ Entry } & \multirow{2}{*}{$\begin{array}{l}\text { Equiv } \\
\text { of } 5\end{array}$} & \multirow{2}{*}{$\begin{array}{l}\text { Iodine } \\
\text { (equiv) }\end{array}$} & \multirow{2}{*}{$\begin{array}{c}\mathrm{CH}_{2} \mathrm{Cl}_{2} \\
(\mathrm{~L} / \mathrm{kg})\end{array}$} & \multirow{2}{*}{$\begin{array}{c}\text { Reaction } \\
\text { Temp } \\
\left({ }^{\circ} \mathrm{C}\right)\end{array}$} & \multirow{2}{*}{$\begin{array}{c}\text { Addition } \\
\text { time of } 4 \\
\text { solution }\end{array}$} & \multicolumn{3}{|c|}{$\begin{array}{l}\text { End-of-Reaction } \\
\text { purity ( } \% \text { AN) }\end{array}$} & \multirow{2}{*}{$\begin{array}{c}\text { Assay } \\
\text { yield of } 6\end{array}$} \\
\hline & & & & & & 6 & 9 & 12 & \\
\hline $\begin{array}{l}1-\text { setpoints prior to } \\
\text { DOE }\end{array}$ & 1.10 & 5.6 & 1.7 & 22 & $10 \mathrm{~h}$ & 79.1 & 0.36 & 0.18 & $80.0 \%$ \\
\hline $\begin{array}{l}2 \text { - Increased } 5 \text { charge } \\
\text { only }\end{array}$ & 1.38 & 5.6 & 1.7 & 22 & $10 \mathrm{~h}$ & 82.0 & 0.39 & 0.07 & $87.2 \%$ \\
\hline 3 - Setpoints after DOE & 1.38 & 5.6 & 2.1 & 12 & $15 \mathrm{~h}$ & 82.1 & 0.33 & 0.04 & $88.3 \%$ \\
\hline $\begin{array}{l}4-\text { Stress study of } \\
\text { shortened addition time }\end{array}$ & 1.38 & 5.8 & 2.1 & 12 & $7 \mathrm{~h}$ & 79.6 & 0.35 & 0.11 & $\mathrm{n} / \mathrm{a}^{\mathrm{a}}$ \\
\hline $\begin{array}{l}5-\text { Stress study of } \\
\text { lengthened addition time }\end{array}$ & 1.38 & 5.8 & 2.1 & 12 & $24 \mathrm{~h}$ & 80.3 & 0.34 & 0.04 & $85.8 \%$ \\
\hline
\end{tabular}

Reactions carried out by addition of solution of $\mathbf{4}$ to premixed pot of iodine, BSA, and $\mathbf{5}$ in dichloromethane over the time indicated. ${ }^{a}$ Yield was not determined for this trial. 


\section{S3. Approaches Taken to Mitigate Emulsion in Iodoetherification Process Workup}

\section{Use of Isopropyl Acetate to Break Emulsion}

Following quenching of the iodoetherification reaction mixture into aqueous sodium sulfite and sodium bicarbonate, the organic layer had a typical water content ranging from $2-4 \%$ as measured by Karl Fischer titration. A typical iodoetherification process stream after quenching and settling of the layers is shown in Figure S13(a). The organic layer (lower) in this trial contained 3.79\% water, and several hours of additional settling time yielded no further clarification of the layers.

\section{Figure S13. Typical Appearance of Quenched Iodoetherification Reaction}

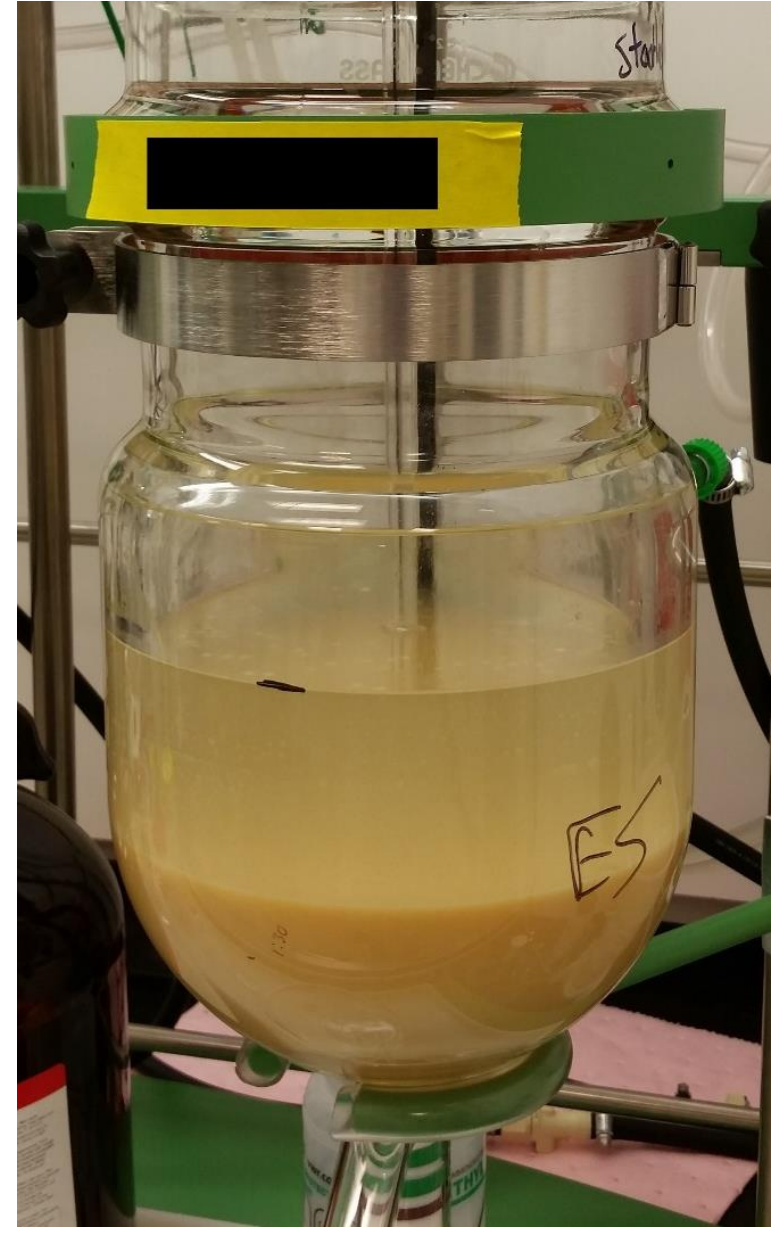

(a) Quenched iodoetherification reaction mixture after settling of layers in a $2 \mathrm{~L}$ reactor

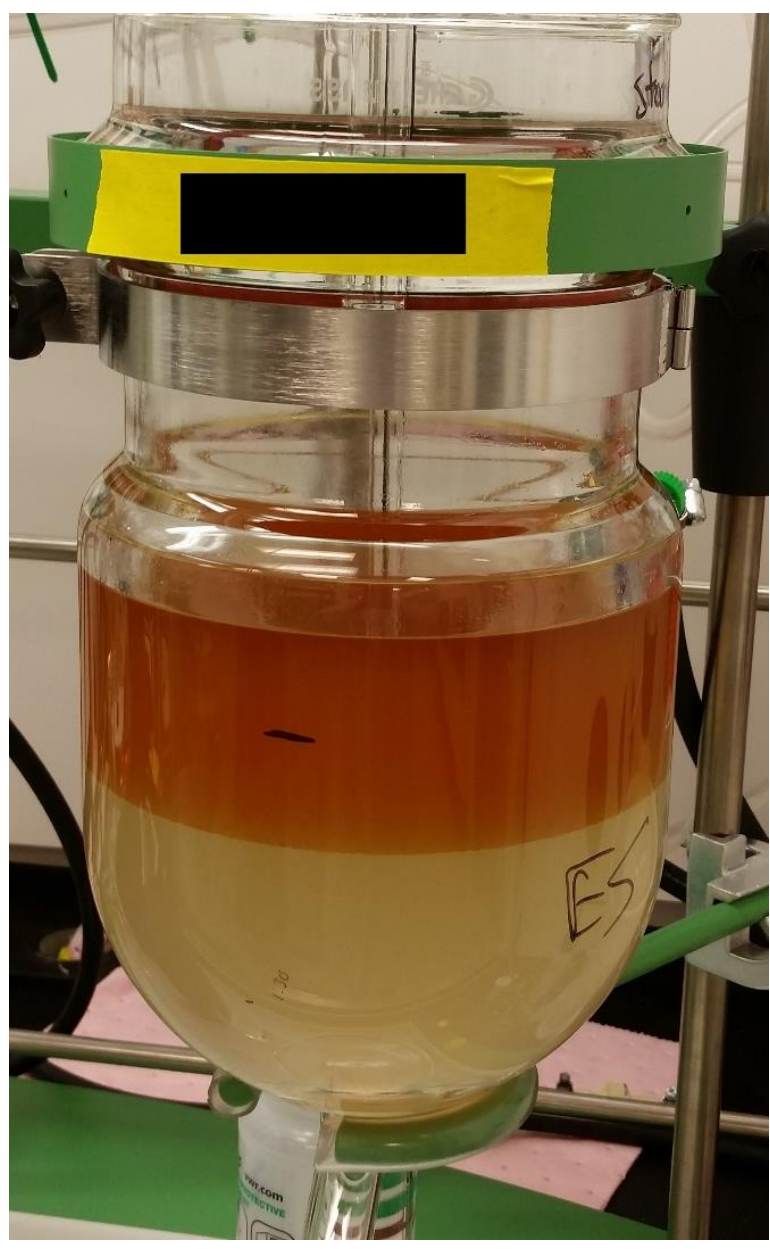

(b) Quenched iodoetherification reaction mixture after addition of $8 \mathrm{~kg} / \mathrm{kg}$ iPrOAc, agitation, and settling

This same mixture is shown in Figure $\mathbf{S 1 3 ( b )}$ after addition of $8 \mathrm{~kg} / \mathrm{kg}$ of iPrOAc, which rapidly broke the emulsion and yielded a much clearer organic phase, now the top layer due to the addition of the less dense iPrOAc. The water content of the organic layer after addition of iPrOAc was $1.02 \%$, which after further treatment with $1.3 \mathrm{~kg} / \mathrm{kg}$ of $\mathrm{MgSO}_{4}$ and filtration was reduced to $0.26 \%$. When this solution was subsequently distilled, minimal hydrolytic degradation was observed. 


\section{Use of a Cellulose Depth Filter to Break Emulsion}

As proof-of-concept for the use of a cellulose filter as a coalescing filter to separate the emulsified water droplets contained in the organic layer, $100 \mathrm{~mL}$ of a typical, turbid organic layer was passed through a Pall Supracap 50 PDE2 cellulose depth filter cartridge (nominal retention 0.2-3.5 $\mu \mathrm{m}$, $22 \mathrm{~cm}^{2}$ surface area, P/N SC050PDE2). After filtration, the previously turbid layer was now clear with a few $\mathrm{mL}$ of separated water residing on top of the layer. This technique was further demonstrated on a scale of $50 \mathrm{~g}$ input of $\mathbf{4}$ using the same type of filter. In this trial, the organic layer (total volume $\sim 500 \mathrm{~mL}$ ) was reduced from a water content of $2.15 \%$ to $0.53 \%$ after passage through the depth filter, with approximately $10 \mathrm{~mL}$ of water separated out on top of the organic layer (Figure S14). When this solution of $\mathbf{6}$ in dichloromethane was distilled to exchange into MEK, only minor hydrolytic degradation was observed, as azeotropic drying was effective to remove this level of residual water.

\section{Figure S14. $\quad$ Appearance of Organic Layer Before and After Depth Filtration}

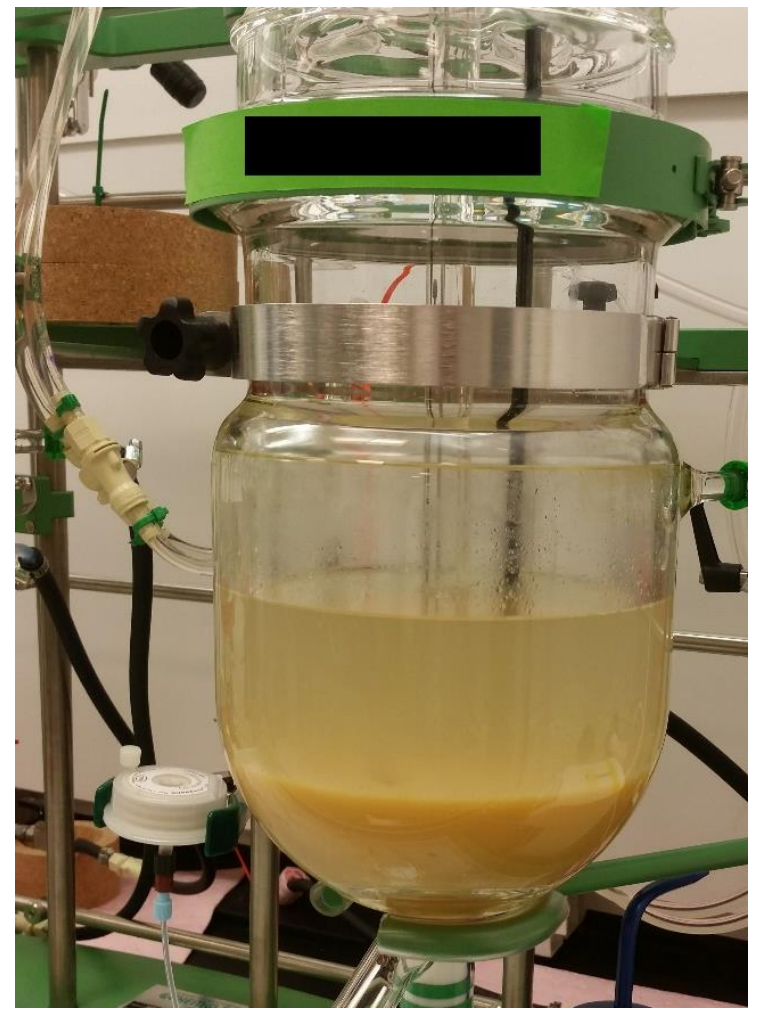

(a) Quenched iodoetherification reaction mixture after settling of layers in a $2 \mathrm{~L}$ reactor. The depth filter cartridge to be used is visible at the lower left.

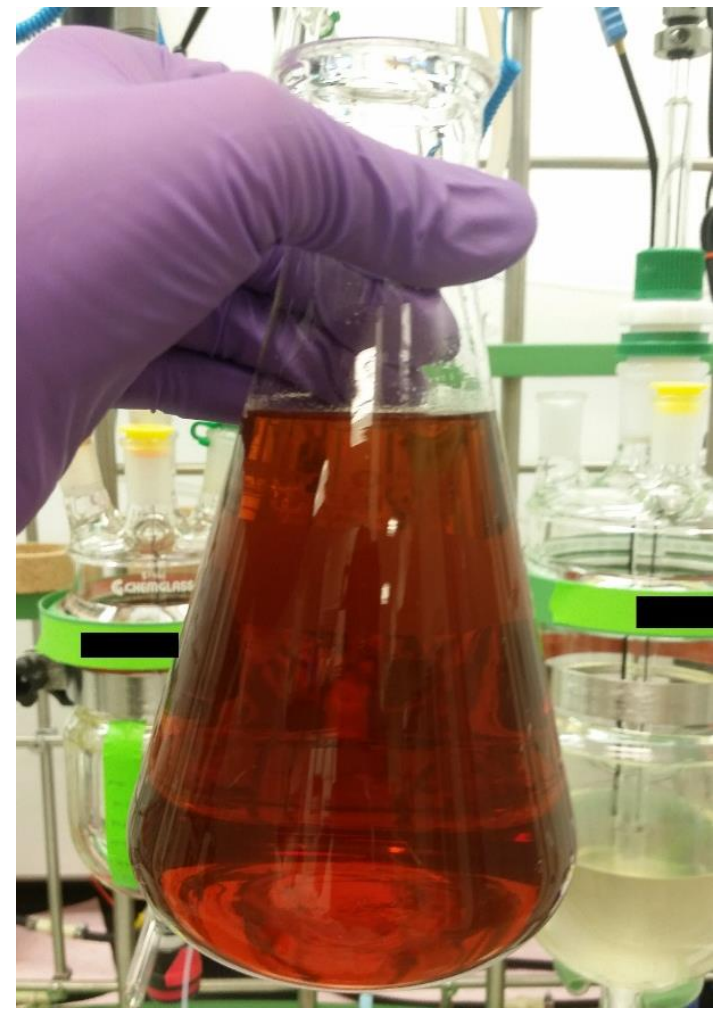

(b) Product-containing organic layer after filtration through a cellulose depth filter. In this photo, the separated aqueous layer has already been removed by an additional layer separation.

The pre-fitted cartridges available from Pall are convenient for use on laboratory scale, as they have Luer fittings and are therefore readily used with large syringes or lab-scale pump equipment. For further scale-ups, loose cellulose depth filter sheets were sourced from Filtrox AG to fit existing processing equipment on hand, with Filtrox Purafix filter sheets (P/N CH 100P, nominal retention $0.6-1.5 \mu \mathrm{m}$ ) selected for the process. 


\section{S4. NMR Spectra}

\section{Annotated Chemical Shift Data}

Compound 4. ${ }^{1} \mathrm{H}$ NMR (400 MHz, DMSO-d $\left.d_{6}\right) \delta .09$ (d, $\left.J=3.5 \mathrm{~Hz}, 1 \mathrm{H}\right), 8.02(\mathrm{~s}, 1 \mathrm{H}), 7.90-$ $7.83(\mathrm{~m}, 6 \mathrm{H}), 7.66-7.60(\mathrm{~m}, 3 \mathrm{H}), 7.59-7.52(\mathrm{~m}, 6 \mathrm{H}), 7.26(\mathrm{dd}, 1 \mathrm{H}), 6.75(\mathrm{dd}, J=28.6,5.9 \mathrm{~Hz}$, $1 \mathrm{H}), 5.82$ (ddd, $J=60.1,5.9,2.6 \mathrm{~Hz}, 1 \mathrm{H}), 5.64(\mathrm{dd}, J=2.2,2.2 \mathrm{~Hz}, 1 \mathrm{H}) .{ }^{13} \mathrm{C}\left\{{ }^{1} \mathrm{H}\right\} \mathrm{NMR}(101$ MHz, DMSO- $\left.d_{6}\right) \delta 160.4(\mathrm{~d}, J=6.3 \mathrm{~Hz}), 153.5(\mathrm{~d}, J=12.1 \mathrm{~Hz}), 151.8,149.9(\mathrm{~d}, J=5.1 \mathrm{~Hz})$, $138.8(\mathrm{~d}, J=6.5 \mathrm{~Hz}), 132.7(\mathrm{~d}, J=9.9 \mathrm{~Hz}), 132.3(\mathrm{~d}, J=2.9 \mathrm{~Hz}), 128.7(\mathrm{~d}, J=12.2 \mathrm{~Hz}), 128.4(\mathrm{~d}$, $J=99.9 \mathrm{~Hz}), 125.1(\mathrm{~d}, J=24.3 \mathrm{~Hz}), 101.1(\mathrm{~d}, J=16.6 \mathrm{~Hz}), 90.4(\mathrm{~d}, J=192.9 \mathrm{~Hz}), 83.6(\mathrm{~d}, J=$ $14.5 \mathrm{~Hz}) .{ }^{19} \mathrm{~F}$ NMR $\left(376 \mathrm{MHz}, \mathrm{DMSO}-d_{6}\right) \delta-167.4$ (dddd, $\left.J=60.4,28.7,4.0,4.0 \mathrm{~Hz}\right) .{ }^{31} \mathrm{P}\left\{{ }^{1} \mathrm{H}\right\}$ NMR (162 MHz, DMSO-d $d_{6} \delta 16.3$.

Compound 6a. ${ }^{1} \mathrm{H}$ NMR (400 MHz, DMSO- $\left.d_{6}\right) \delta 12.16$ (br s, $\left.2 \mathrm{H}\right), 8.19(\mathrm{~d}, J=4.0 \mathrm{~Hz}, 1 \mathrm{H}), 8.01$ (s, 1H), $7.90-7.81(\mathrm{~m}, 6 \mathrm{H}), 7.65-7.59(\mathrm{~m}, 3 \mathrm{H}), 7.58-7.52(\mathrm{~m}, 6 \mathrm{H}), 7.41-7.35(\mathrm{~m}, 2 \mathrm{H}), 7.29$ $-7.24(\mathrm{~m}, 2 \mathrm{H}), 7.21-7.16(\mathrm{~m}, 1 \mathrm{H}), 6.86(\mathrm{dd}, J=18.1,4.2 \mathrm{~Hz}, 1 \mathrm{H}), 5.96(\mathrm{dd}, J=12.2,10.4 \mathrm{~Hz}$, $1 \mathrm{H}), 5.70(\mathrm{~s}, 1 \mathrm{H}), 5.67(\mathrm{dd}, J=53.1,4.5 \mathrm{~Hz}, 1 \mathrm{H}), 4.73(\mathrm{~d}, J=17.1 \mathrm{~Hz}, 1 \mathrm{H}), 4.17-3.88(\mathrm{~m}, 5 \mathrm{H})$, $2.45(\mathrm{~s}, 4 \mathrm{H}), 1.20(\mathrm{~d}, J=7.1 \mathrm{~Hz}, 3 \mathrm{H}), 1.16(\mathrm{t}, J=7.1,7.1 \mathrm{~Hz}, 3 \mathrm{H}) .{ }^{13} \mathrm{C}\left\{{ }^{1} \mathrm{H}\right\} \mathrm{NMR}(101 \mathrm{MHz}$, DMSO-d $\left.d_{6}\right) \delta 173.6,173.4(\mathrm{~d}, J=3.5 \mathrm{~Hz}), 160.4(\mathrm{~d}, J=6.4 \mathrm{~Hz}), 151.7,150.2(\mathrm{~d}, J=8.9 \mathrm{~Hz}), 149.8$ $(\mathrm{d}, J=5.1 \mathrm{~Hz}), 139.6(\mathrm{~d}, J=6.4 \mathrm{~Hz}), 132.8(\mathrm{~d}, J=9.9 \mathrm{~Hz}), 132.3(\mathrm{~d}, J=2.8 \mathrm{~Hz}), 129.6,128.8(\mathrm{~d}$, $J=12.1 \mathrm{~Hz}), 128.4(\mathrm{~d}, J=99.9 \mathrm{~Hz}), 125.1(\mathrm{~d}, J=24.1 \mathrm{~Hz}), 124.6,120.6(\mathrm{~d}, J=4.4 \mathrm{~Hz}), 110.8(\mathrm{~d}$, $J=13.2 \mathrm{~Hz}), 94.6(\mathrm{~d}, J=200.5 \mathrm{~Hz}), 83.0(\mathrm{~d}, J=16.1 \mathrm{~Hz}), 63.8(\mathrm{~d}, J=156.4 \mathrm{~Hz}), 60.6,49.2,28.8$, $21.7(\mathrm{~d}, J=20.0 \mathrm{~Hz}), 20.2(\mathrm{~d}, J=5.4 \mathrm{~Hz}), 14.0 .{ }^{19} \mathrm{~F}$ NMR $\left(376 \mathrm{MHz}, \mathrm{DMSO}-d_{6}\right) \delta-168.7$ (ddd, $J$ $=52.8,17.8,17.8 \mathrm{~Hz}) .{ }^{31} \mathrm{P}\left\{{ }^{1} \mathrm{H}\right\} \mathrm{NMR}\left(162 \mathrm{MHz}, \mathrm{DMSO}-d_{6}\right) \delta 20.8,16.3$.

Compound 1b. ${ }^{1} \mathrm{H}$ NMR (400 MHz, DMSO- $\left.d_{6}\right) \delta 12.15$ (br s, $\left.1 \mathrm{H}\right), 9.95$ (br s, $\left.1 \mathrm{H}\right), 8.21(\mathrm{~s}, 1 \mathrm{H})$, $8.21(\mathrm{~s}, 1 \mathrm{H}), 7.47-7.43(\mathrm{~m}, 4 \mathrm{H}), 7.33-7.25(\mathrm{~m}, 2 \mathrm{H}), 7.16-7.08(\mathrm{~m}, 3 \mathrm{H}), 6.88-6.83(\mathrm{~m}, 2 \mathrm{H})$, $6.14(\mathrm{dd}, J=1.5,1.5 \mathrm{~Hz}, 1 \mathrm{H}), 5.97(\mathrm{~d}, J=3.9 \mathrm{~Hz}, 1 \mathrm{H}), 5.79(\mathrm{dd}, J=12.3,10.3 \mathrm{~Hz}, 1 \mathrm{H}), 4.10-$ $3.85(\mathrm{~m}, 5 \mathrm{H}), 3.81(\mathrm{~s}, 3 \mathrm{H}), 1.16(\mathrm{~d}, J=7.1 \mathrm{~Hz}, 3 \mathrm{H}), 1.12(\mathrm{t}, J=7.1,7.1 \mathrm{~Hz}, 3 \mathrm{H}) .{ }^{13} \mathrm{C}\left\{{ }^{1} \mathrm{H}\right\} \mathrm{NMR}$ $\left(101 \mathrm{MHz}, \mathrm{DMSO}-d_{6}\right) \delta 173.3(\mathrm{~d}, J=3.7 \mathrm{~Hz}), 167.3,157.2(\mathrm{~d}, J=284.2 \mathrm{~Hz}), 156.2,153.3,151.2$, $150.1(\mathrm{~d}, J=8.7 \mathrm{~Hz}), 149.4,147.3,138.4,129.5,124.5,123.5,121.7,120.6(\mathrm{~d}, J=4.5 \mathrm{~Hz}), 118.7$, $115.1,112.8,105.6(\mathrm{~d}, J=7.1 \mathrm{~Hz}), 105.0(\mathrm{dd}, J=14.1,14.1 \mathrm{~Hz}), 79.0(\mathrm{~d}, J=29.2 \mathrm{~Hz}), 63.3(\mathrm{~d}, J$ $=156.0 \mathrm{~Hz}), 60.5,55.6,49.1,20.3(\mathrm{~d}, J=5.3 \mathrm{~Hz}), 13.9 .{ }^{19} \mathrm{~F}$ NMR $\left(376 \mathrm{MHz}, \mathrm{DMSO}-d_{6}\right) \delta-133.4$ $(\mathrm{dd}, J=4.4,4.4 \mathrm{~Hz}) .{ }^{31} \mathrm{P}\left\{{ }^{1} \mathrm{H}\right\} \mathrm{NMR}\left(162 \mathrm{MHz}, \mathrm{DMSO}-d_{6}\right) \delta 21.2$.

Compound 1. ${ }^{1} \mathrm{H}$ NMR (400 MHz, DMSO- $\left.d_{6}\right) \delta 8.23(\mathrm{~s}, 2 \mathrm{H}), 7.49$ (br s, 2H), $7.32-7.25$ (m, 2H), $7.15-7.10(\mathrm{~m}, 3 \mathrm{H}), 6.89(\mathrm{~d}, J=3.0 \mathrm{~Hz}, 1 \mathrm{H}), 6.14(\mathrm{dd}, J=1.1,1.1 \mathrm{~Hz}, 1 \mathrm{H}), 5.99(\mathrm{~d}, J=4.1 \mathrm{~Hz}$, $1 \mathrm{H}), 5.82(\mathrm{dd}, J=12.3,10.3 \mathrm{~Hz}, 1 \mathrm{H}), 4.14-3.85(\mathrm{~m}, 5 \mathrm{H}), 1.17(\mathrm{~d}, J=7.2 \mathrm{~Hz}, 3 \mathrm{H}), 1.11(\mathrm{t}, J=$ 7.1, 7.1 Hz, 3H). ${ }^{13} \mathrm{C}\left\{{ }^{1} \mathrm{H}\right\}$ NMR $\left(101 \mathrm{MHz}, \mathrm{DMSO}-d_{6}\right) \delta 173.3(\mathrm{~d}, J=3.7 \mathrm{~Hz}), 157.2(\mathrm{~d}, J=284.3$ $\mathrm{Hz}$ ), 156.2, 153.3, 150.1 (d, $J=8.5 \mathrm{~Hz}$ ), 149.4, 138.4, 129.5, 124.5, 120.6 (d, $J=4.4 \mathrm{~Hz}), 118.7$, $105.6(\mathrm{~d}, J=7.0 \mathrm{~Hz}), 105.0(\mathrm{dd}, J=14.0,14.0 \mathrm{~Hz}), 79.0(\mathrm{~d}, J=29.3 \mathrm{~Hz}), 63.3(\mathrm{~d}, J=156.1 \mathrm{~Hz})$, 60.5, 49.1, 20.3 (d, $J=5.4 \mathrm{~Hz}$ ), 13.9. ${ }^{19} \mathrm{~F}$ NMR (376 MHz, DMSO- $\left.d_{6}\right) \delta-133.4$ (dd, $J=3.6,3.6$ $\mathrm{Hz}) .{ }^{31} \mathrm{P}\left\{{ }^{1} \mathrm{H}\right\}$ NMR (162 MHz, DMSO-d $) \delta 21.2$. 
${ }^{1} \mathrm{H}$ NMR Spectrum of $\mathbf{4}$

\begin{tabular}{lll} 
& \multicolumn{1}{c}{ Parameter } & \multicolumn{1}{c}{ Value } \\
1 & Solvent & DMSO \\
2 & Pulse Sequence & zg30 \\
3 & Experiment & $1 \mathrm{D}$ \\
4 & Number of Scans & 32 \\
5 & Receiver Gain & 30.9 \\
6 & Relaxation Delay & 1.0000 \\
7 & Pulse Width & 10.0000 \\
8 & Acquisition Time & 4.0894 \\
9 & Spectrometer Frequency & 400.13 \\
10 & Spectral Width & 8012.8 \\
11 & Nucleus & $1 \mathrm{H}$ \\
12 Spectral Size & 65536
\end{tabular}

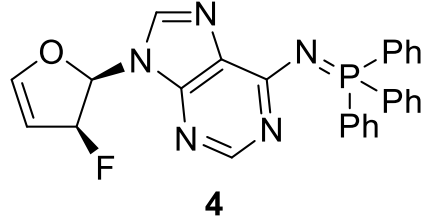

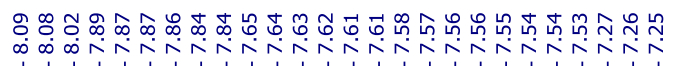

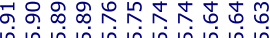
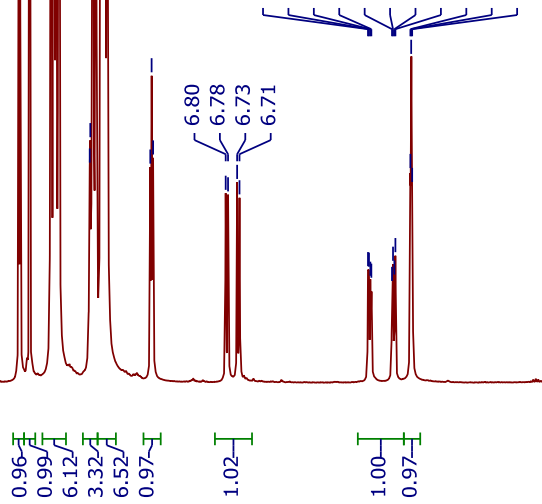

6

* indicates extraneous peak due to impurity: water (3.37 ppm), acetonitrile (2.08 ppm), isopropyl acetate (1.96, $1.17 \mathrm{ppm})$ 
${ }^{1} \mathrm{H}$ NMR Spectrum of $\mathbf{4}$, expansion

\begin{tabular}{lll}
\multicolumn{1}{c}{ Parameter } & \multicolumn{1}{c}{ Value } \\
1 Solvent & DMSO \\
2 Pulse Sequence & zg30 \\
3 Experiment & $1 \mathrm{D}$ \\
4 Number of Scans & 32 \\
5 Receiver Gain & 30.9 \\
6 Relaxation Delay & 1.0000 \\
7 Pulse Width & 10.0000 \\
8 Acquisition Time & 4.0894 \\
9 Spectrometer Frequency & 400.13 \\
10 & Spectral Width & 8012.8 \\
11 & Nucleus & $1 \mathrm{H}$ \\
12 Spectral Size & 65536
\end{tabular}
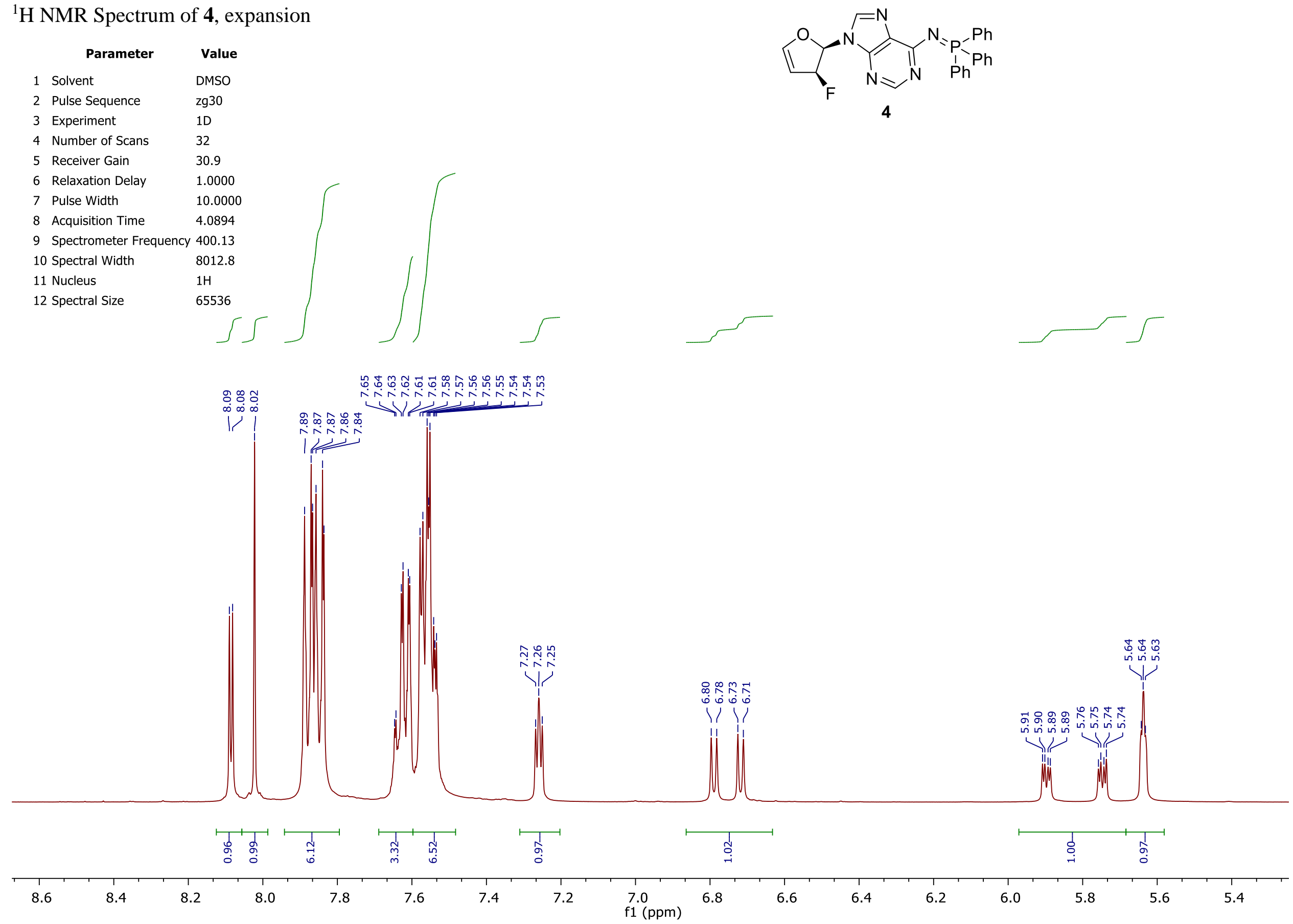
${ }^{13} \mathrm{C}\left\{{ }^{1} \mathrm{H}\right\}$ NMR Spectrum of $\mathbf{4}$

\begin{tabular}{lll} 
& \multicolumn{1}{c}{ Parameter } & \multicolumn{1}{c}{ Value } \\
1 & Solvent & DMSO \\
2 & Pulse Sequence & zgpg30 \\
3 & Experiment & $1 \mathrm{D}$ \\
4 & Number of Scans & 4096 \\
5 & Receiver Gain & 205.1 \\
6 & Relaxation Delay & 2.0000 \\
7 & Pulse Width & 10.0000 \\
8 & Acquisition Time & 1.3631 \\
9 & Spectrometer Frequency & 100.62 \\
10 & Spectral Width & 24038.5 \\
11 & Nucleus & $13 \mathrm{C}$ \\
12 Spectral Size & 65536
\end{tabular}

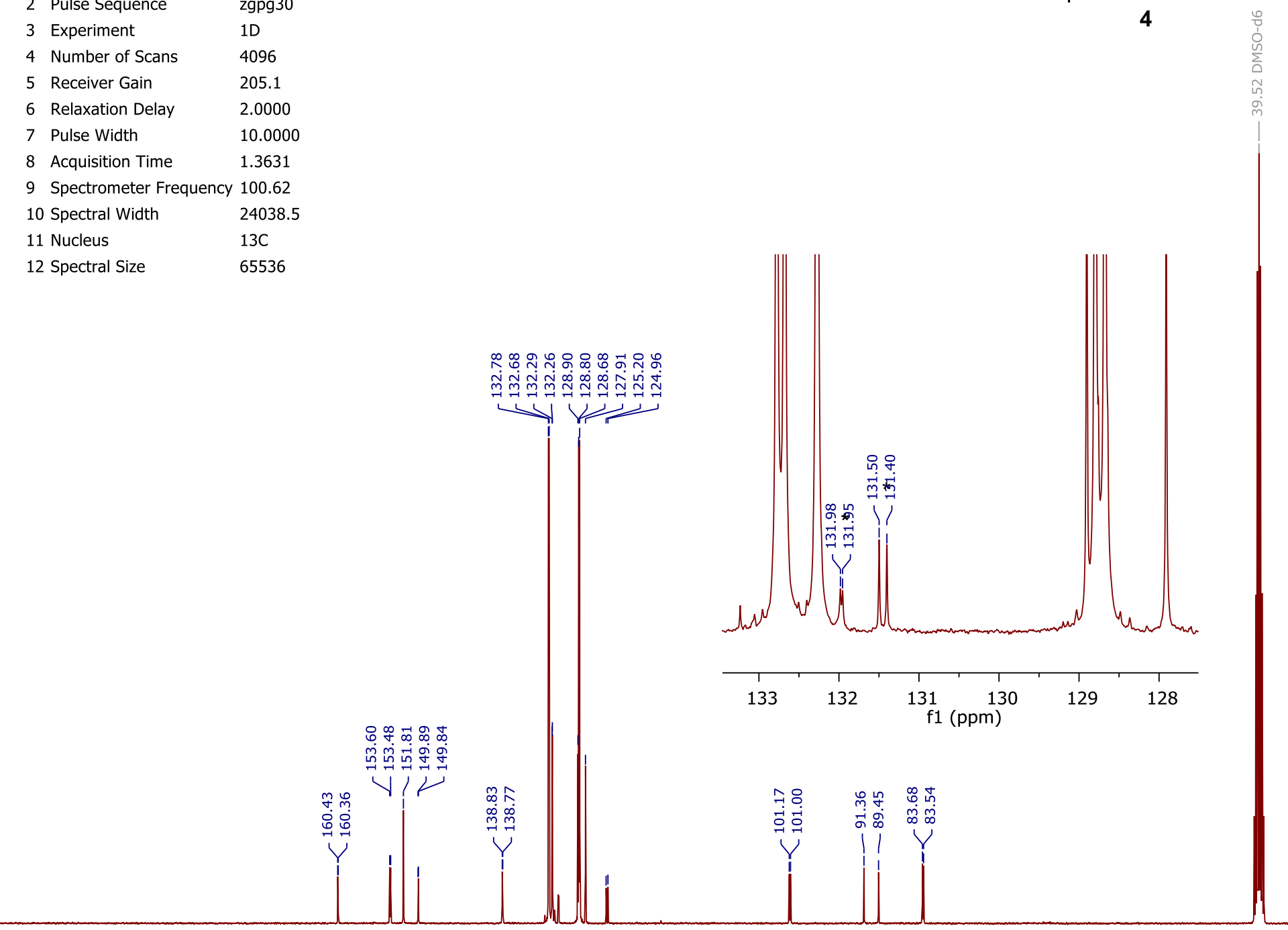

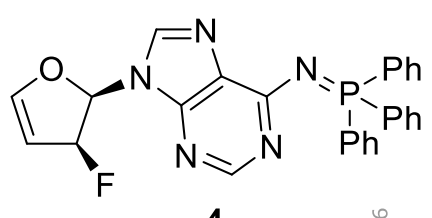

4

\begin{tabular}{|c|c|c|c|c|c|c|c|c|c|c|c|c|c|c|c|c|c|c|c|c|}
\hline$T$ & 1 & $T$ & 1 & & & $T$ & 1 & 1 & $T$ & 1 & $T$ & 1 & $T$ & $T$ & $T$ & $T$ & $T$ & $T$ & $T$ & $T$ \\
\hline 200 & 190 & 180 & 170 & 160 & 150 & 140 & 130 & 120 & 110 & $\begin{array}{c}100 \quad 90 \\
\mathrm{f} 1(\mathrm{ppm})\end{array}$ & 80 & 70 & 60 & 50 & 40 & 30 & 20 & 10 & 0 & -10 \\
\hline
\end{tabular}


${ }^{19}$ F NMR Spectrum of 4

\begin{tabular}{lll} 
& \multicolumn{1}{c}{ Parameter } & \multicolumn{1}{c}{ Value } \\
1 & Solvent & DMSO \\
2 & Pulse Sequence & zgflqn \\
3 & Experiment & $1 \mathrm{D}$ \\
4 & Number of Scans & 64 \\
5 & Receiver Gain & 205.1 \\
6 & Relaxation Delay & 1.0000 \\
7 & Pulse Width & 18.0000 \\
8 & Acquisition Time & 0.7340 \\
9 & Spectrometer Frequency & 376.46 \\
10 & Spectral Width & 89285.7 \\
11 & Nucleus & $19 \mathrm{~F}$ \\
12 Spectral Size & 131072
\end{tabular}

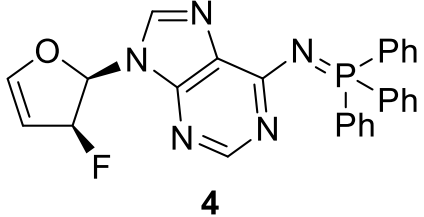

4

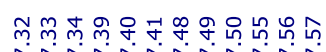

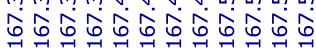

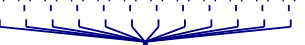

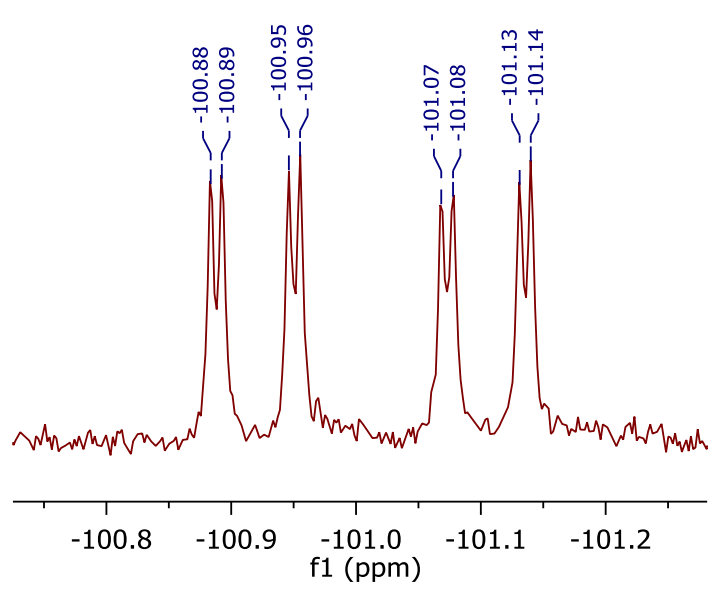

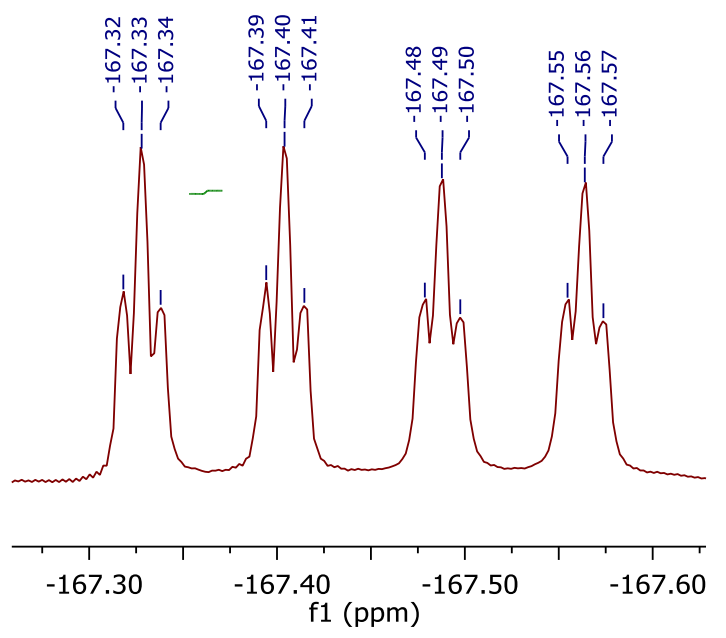

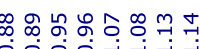

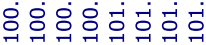
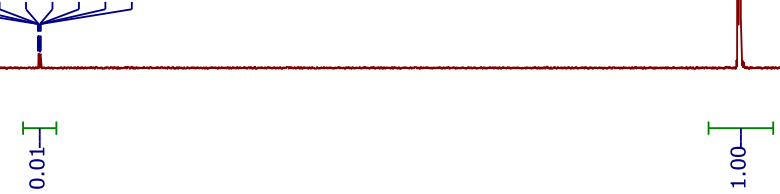

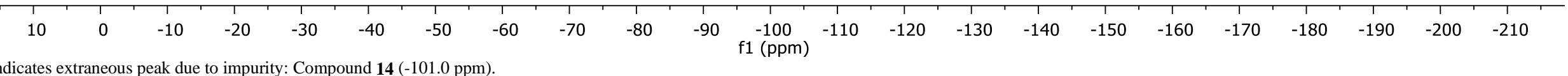




\section{${ }^{31} \mathrm{P}\left\{{ }^{1} \mathrm{H}\right\}$ NMR Spectrum of 4}

\begin{tabular}{lll} 
& \multicolumn{1}{c}{ Parameter } & \multicolumn{1}{c}{ Value } \\
1 & Solvent & DMSO \\
2 & Pulse Sequence & zgpg30 \\
3 & Experiment & $1 \mathrm{D}$ \\
4 & Number of Scans & 64 \\
5 & Receiver Gain & 205.1 \\
6 & Relaxation Delay & 2.0000 \\
7 & Pulse Width & 8.0000 \\
8 & Acquisition Time & 0.5112 \\
9 & Spectrometer Frequency & 161.97 \\
10 & Spectral Width & 64102.6 \\
11 & Nucleus & $31 \mathrm{P}$ \\
12 Spectral Size & 65536
\end{tabular}
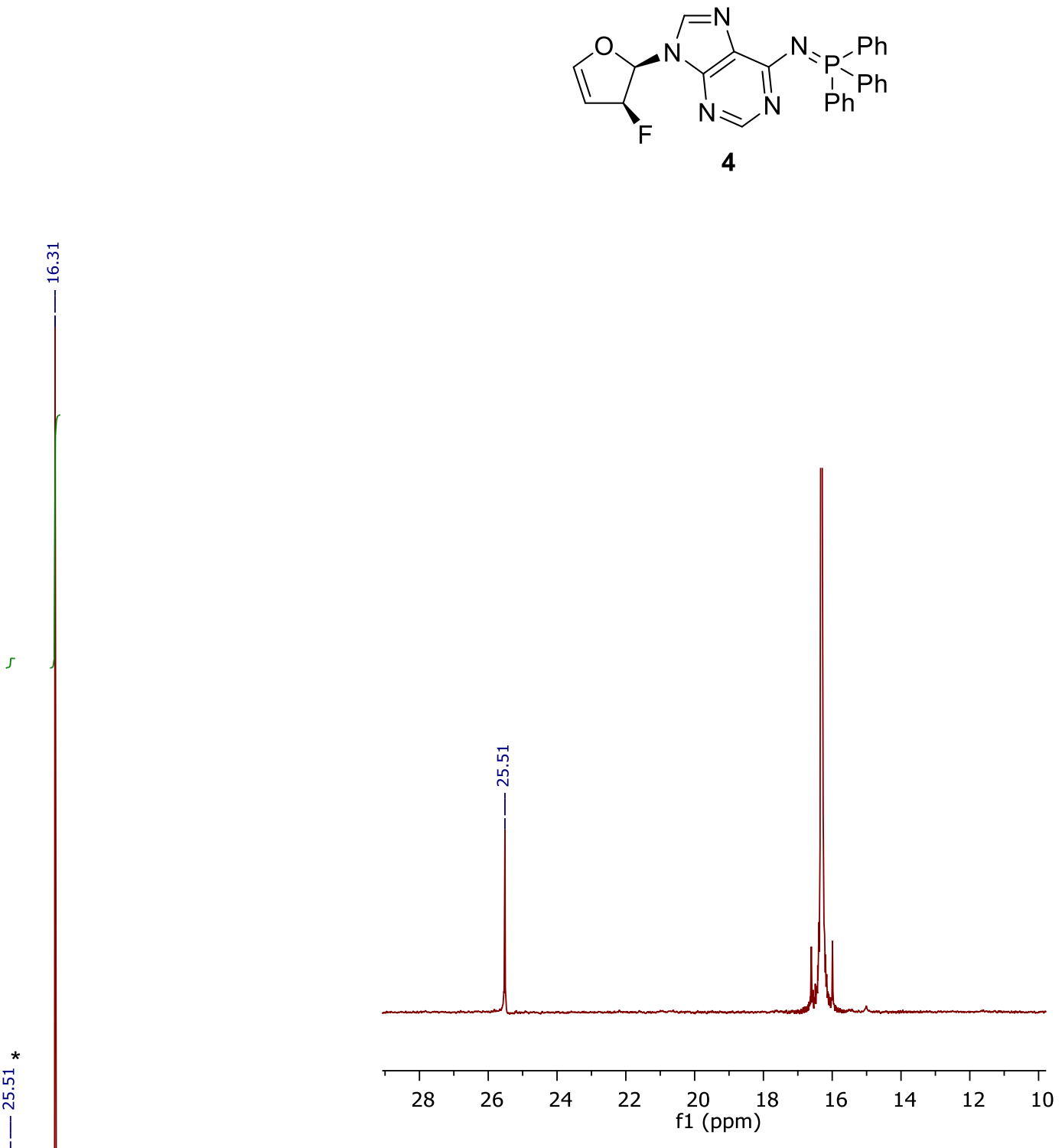

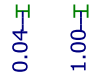

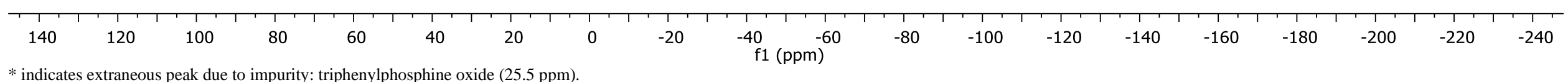

* indicates extraneous peak due to impurity: triphenylphosphine oxide (25.5 ppm). 
${ }^{1} \mathrm{H}$ NMR Spectrum of $\mathbf{6 a}$

\begin{tabular}{lll} 
& \multicolumn{1}{c}{ Parameter } & \multicolumn{1}{c}{ Value } \\
1 & Solvent & DMSO \\
2 & Pulse Sequence & zg30 \\
3 & Experiment & $1 \mathrm{D}$ \\
4 & Number of Scans & 32 \\
5 & Receiver Gain & 30.9 \\
6 & Relaxation Delay & 1.0000 \\
7 & Pulse Width & 10.0000 \\
8 & Acquisition Time & 4.0894 \\
9 & Spectrometer Frequency & 400.13 \\
10 & Spectral Width & 8012.8 \\
11 & Nucleus & $1 \mathrm{H}$ \\
12 Spectral Size & 65536
\end{tabular}

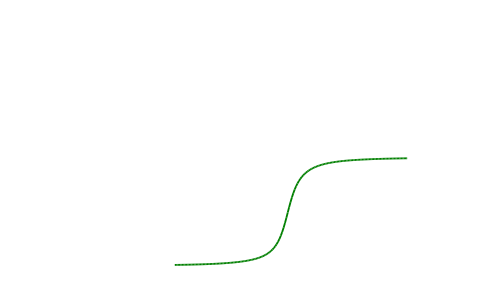

536

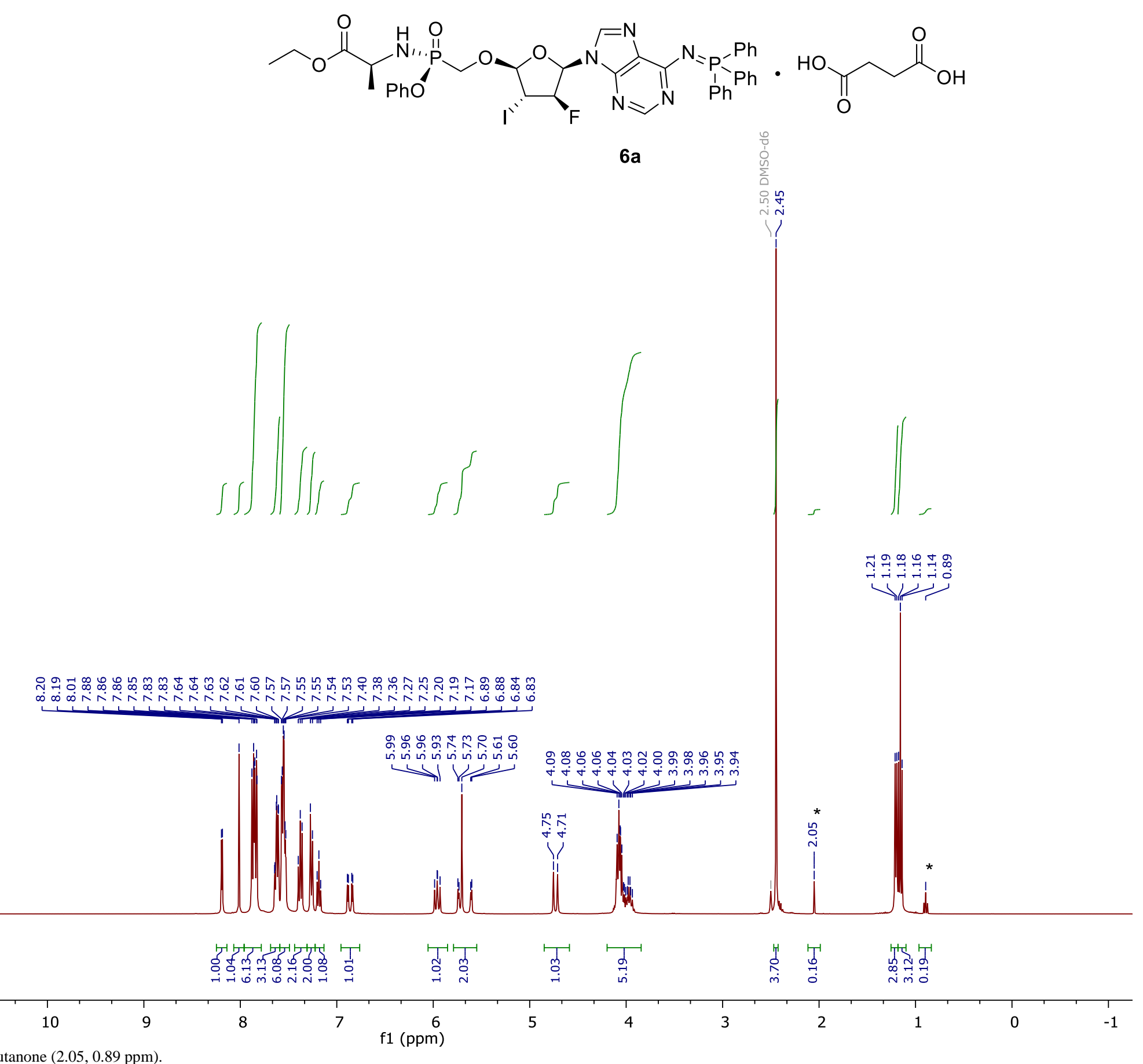

* indicates extraneous peak due to impurity: 2-butanone (2.05, $0.89 \mathrm{ppm})$. 
${ }^{1} \mathrm{H}$ NMR Spectrum of $\mathbf{6 a}$, expansion

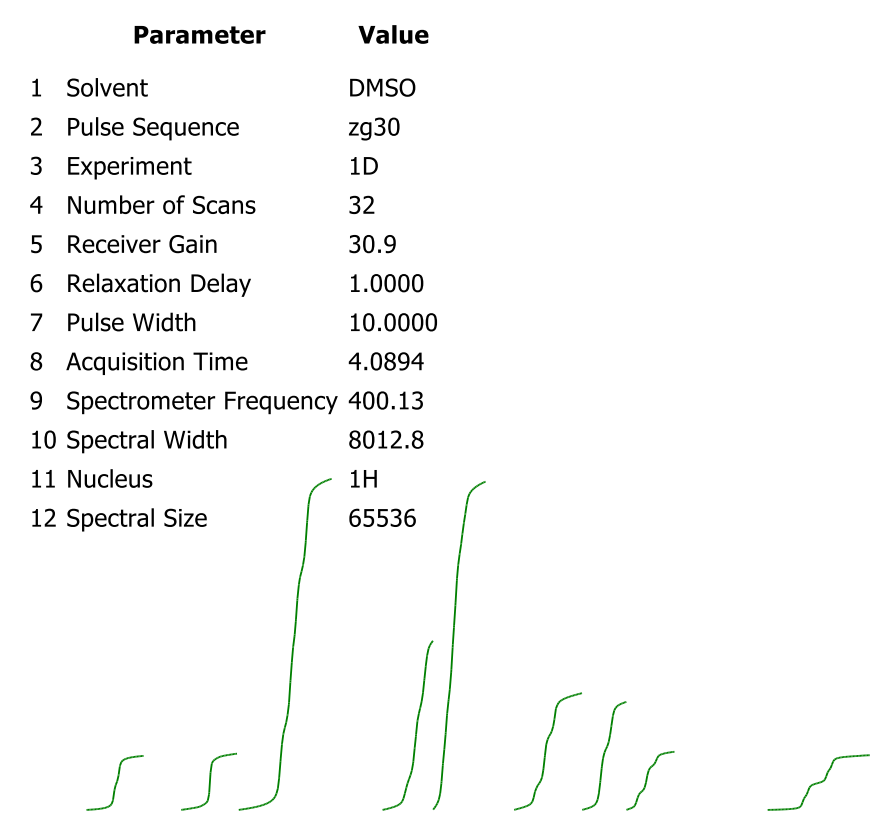

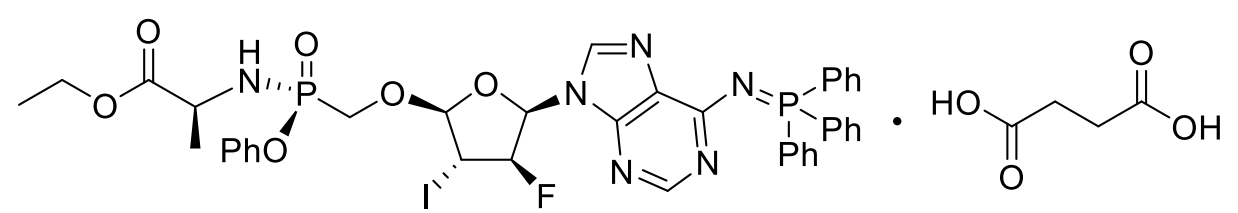

$6 a$

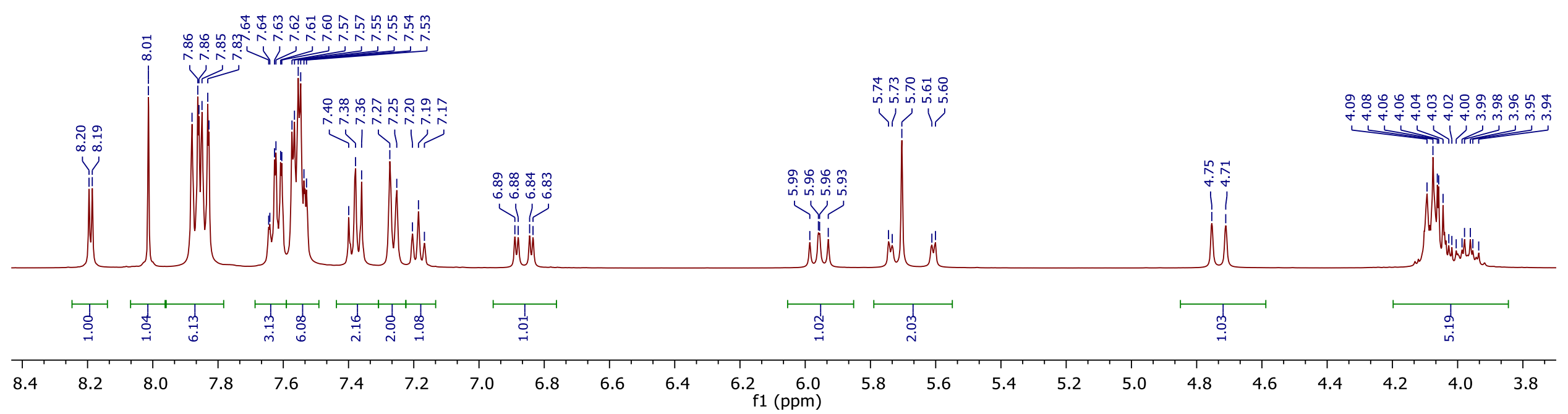




\section{${ }^{13} \mathrm{C}\left\{{ }^{1} \mathrm{H}\right\}$ NMR Spectrum of $\mathbf{6 a}$}

\begin{tabular}{lll}
\multicolumn{1}{c}{ Parameter } & \multicolumn{1}{c}{ Value } \\
1 & Solvent & DMSO \\
2 & Pulse Sequence & zgpg30 \\
3 & Experiment & $1 \mathrm{D}$ \\
4 & Number of Scans & 4096 \\
5 & Receiver Gain & 205.1 \\
6 & Relaxation Delay & 2.0000 \\
7 & Pulse Width & 10.0000 \\
8 & Acquisition Time & 1.3631 \\
9 & Spectrometer Frequency & 100.62 \\
10 & Spectral Width & 24038.5 \\
11 & Nucleus & $13 \mathrm{C}$ \\
12 Spectral Size & 65536
\end{tabular}

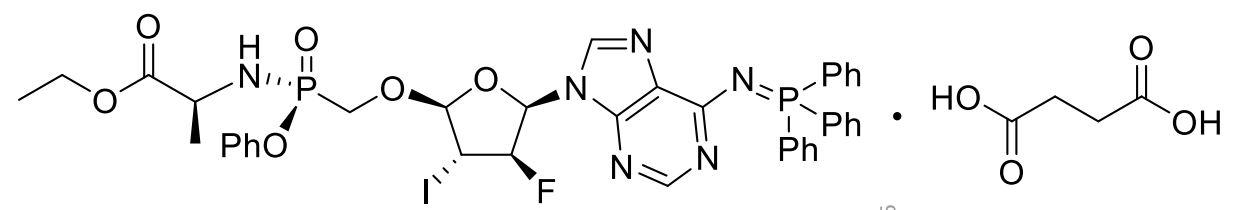

$6 a$
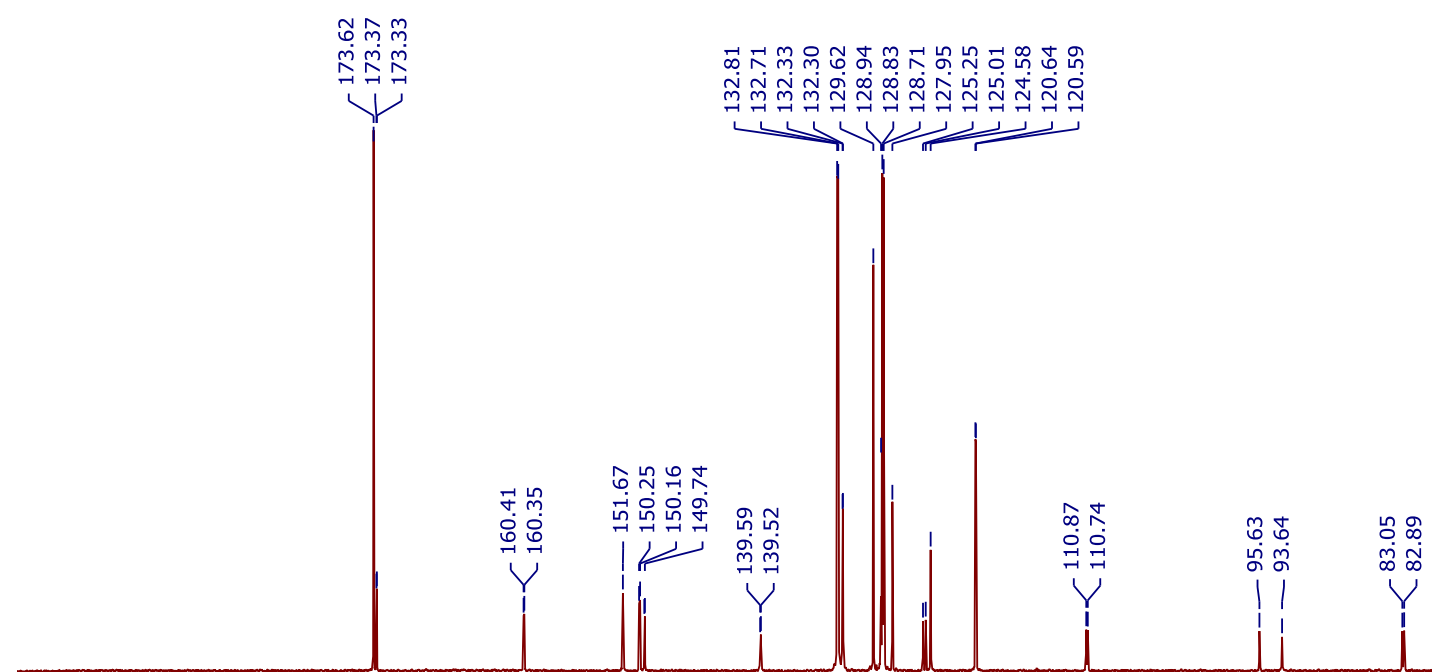

(1)

$\begin{array}{lllllll}200 & 190 & 180 & 170 & 160 & 150 & 140\end{array}$

* indicates extraneous peak due to impurity: MEK (35.9, 29.3, 7.7 ppm). 
${ }^{19}$ F NMR Spectrum of $\mathbf{6 a}$

\begin{tabular}{lll} 
& \multicolumn{1}{c}{ Parameter } & \multicolumn{1}{c}{ Value } \\
1 & Solvent & DMSO \\
2 & Pulse Sequence & zgflqn \\
3 & Experiment & $1 \mathrm{D}$ \\
4 & Number of Scans & 64 \\
5 & Receiver Gain & 205.1 \\
6 & Relaxation Delay & 1.0000 \\
7 & Pulse Width & 18.0000 \\
8 & Acquisition Time & 0.7340 \\
9 & Spectrometer Frequency & 376.46 \\
10 & Spectral Width & 89285.7 \\
11 & Nucleus & $19 \mathrm{~F}$ \\
12 Spectral Size & 131072
\end{tabular}
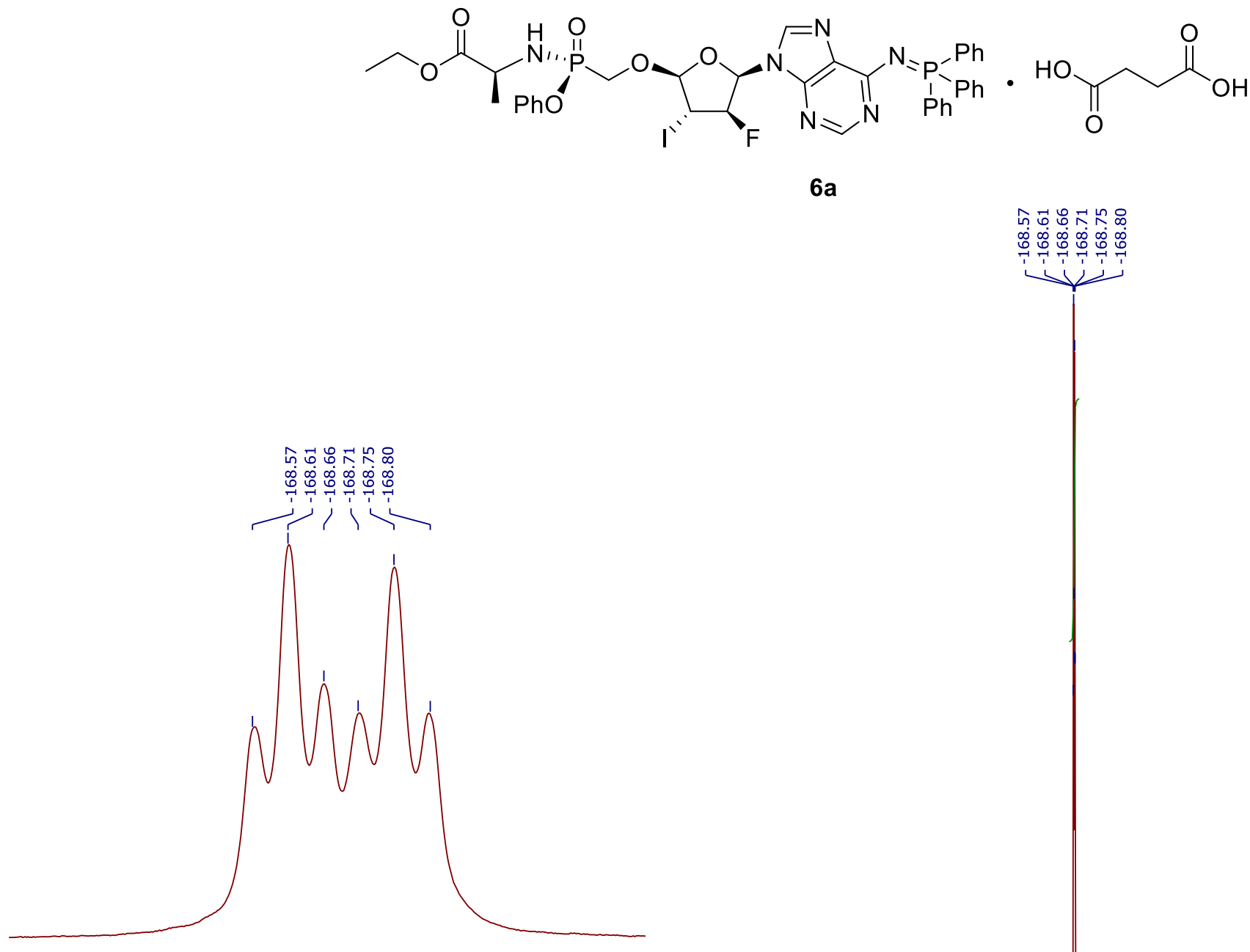

$6 a$

$\begin{array}{llllllll}-168.3 & -168.4 & -168.5 & -168.6 & -168.7 & -168.8 & -168.9 & -169.0\end{array}$ f1 (ppm) 
${ }^{31} \mathrm{P}\left\{{ }^{1} \mathrm{H}\right\}$ NMR Spectrum of $\mathbf{6 a}$

\begin{tabular}{lll}
\multicolumn{1}{c}{ Parameter } & \multicolumn{1}{c}{ Value } \\
1 & Solvent & DMSO \\
2 & Pulse Sequence & zgpg30 \\
3 Experiment & $1 \mathrm{D}$ \\
4 & Number of Scans & 64 \\
5 & Receiver Gain & 205.1 \\
6 & Relaxation Delay & 2.0000 \\
7 & Pulse Width & 8.0000 \\
8 & Acquisition Time & 0.5112 \\
9 & Spectrometer Frequency & 161.97 \\
10 Spectral Width & 64102.6 \\
11 Nucleus & $31 \mathrm{P}$ \\
12 Spectral Size & 65536
\end{tabular}

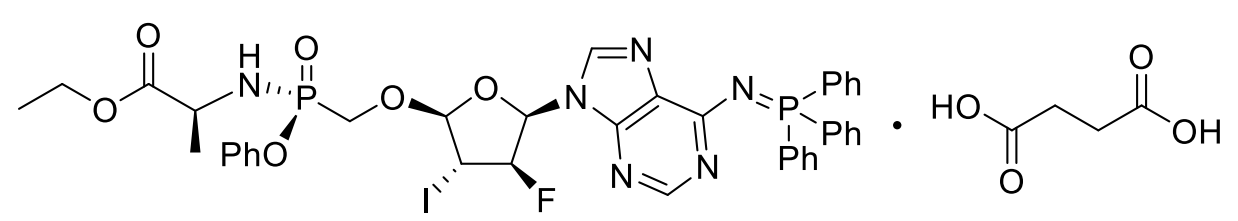

$6 a$

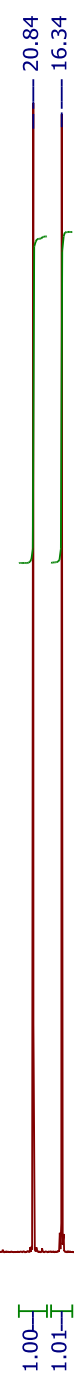

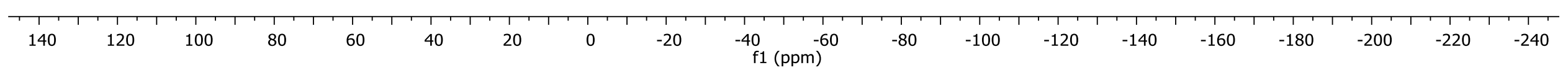


${ }^{1} \mathrm{H}$ NMR Spectrum of $\mathbf{1 b}$

\begin{tabular}{lll} 
& \multicolumn{1}{c}{ Parameter } & \multicolumn{1}{c}{ Value } \\
1 & Solvent & DMSO \\
2 & Pulse Sequence & zg30 \\
3 & Experiment & $1 \mathrm{D}$ \\
4 & Number of Scans & 32 \\
5 & Receiver Gain & 48.8 \\
6 & Relaxation Delay & 1.0000 \\
7 & Pulse Width & 10.0000 \\
8 & Acquisition Time & 4.0894 \\
9 & Spectrometer Frequency & 400.13 \\
10 & Spectral Width & 8012.8 \\
11 & Nucleus & $1 \mathrm{H}$ \\
12 Spectral Size & 65536
\end{tabular}

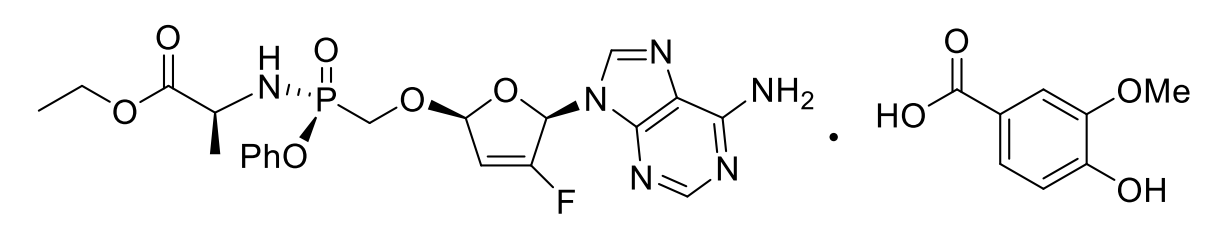

1b

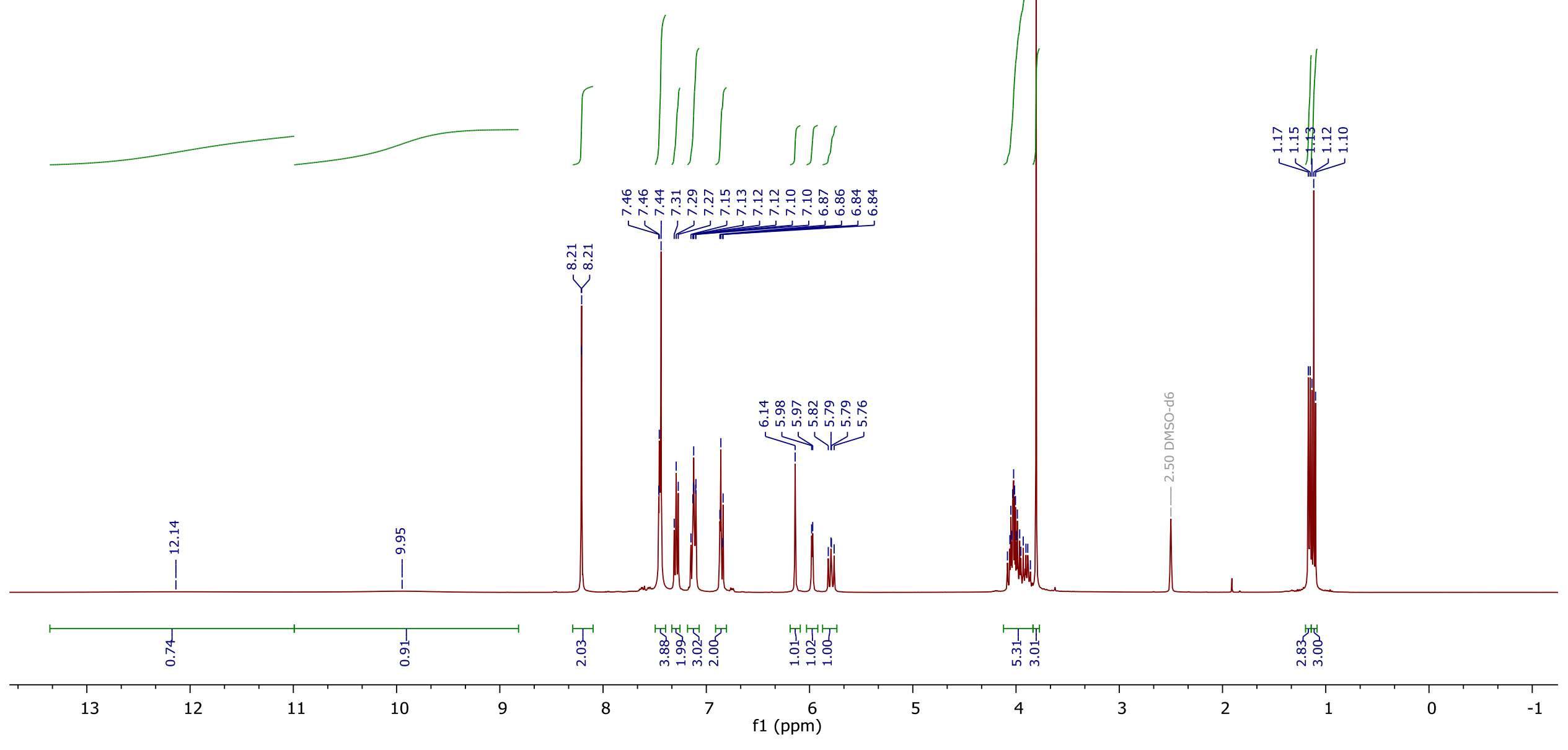


${ }^{1} \mathrm{H}$ NMR Spectrum of $\mathbf{1 b}$, expansion

\begin{tabular}{lll} 
& \multicolumn{1}{c}{ Parameter } & \multicolumn{1}{c}{ Value } \\
1 & Solvent & DMSO \\
2 & Pulse Sequence & zg30 \\
3 & Experiment & $1 \mathrm{D}$ \\
4 & Number of Scans & 32 \\
5 & Receiver Gain & 48.8 \\
6 & Relaxation Delay & 1.0000 \\
7 & Pulse Width & 10.0000 \\
8 & Acquisition Time & 4.0894 \\
9 & Spectrometer Frequency & 400.13 \\
10 & Spectral Width & 8012.8 \\
11 & Nucleus & $1 \mathrm{H}$ \\
12 & Spectral Size & 65536
\end{tabular}<smiles>CCOC(=O)[C@H](C)NP(=O)(O)CO[C@H]1C=C(F)[C@@H](n2cnc3c(N)ncnc32)O1</smiles>

1b
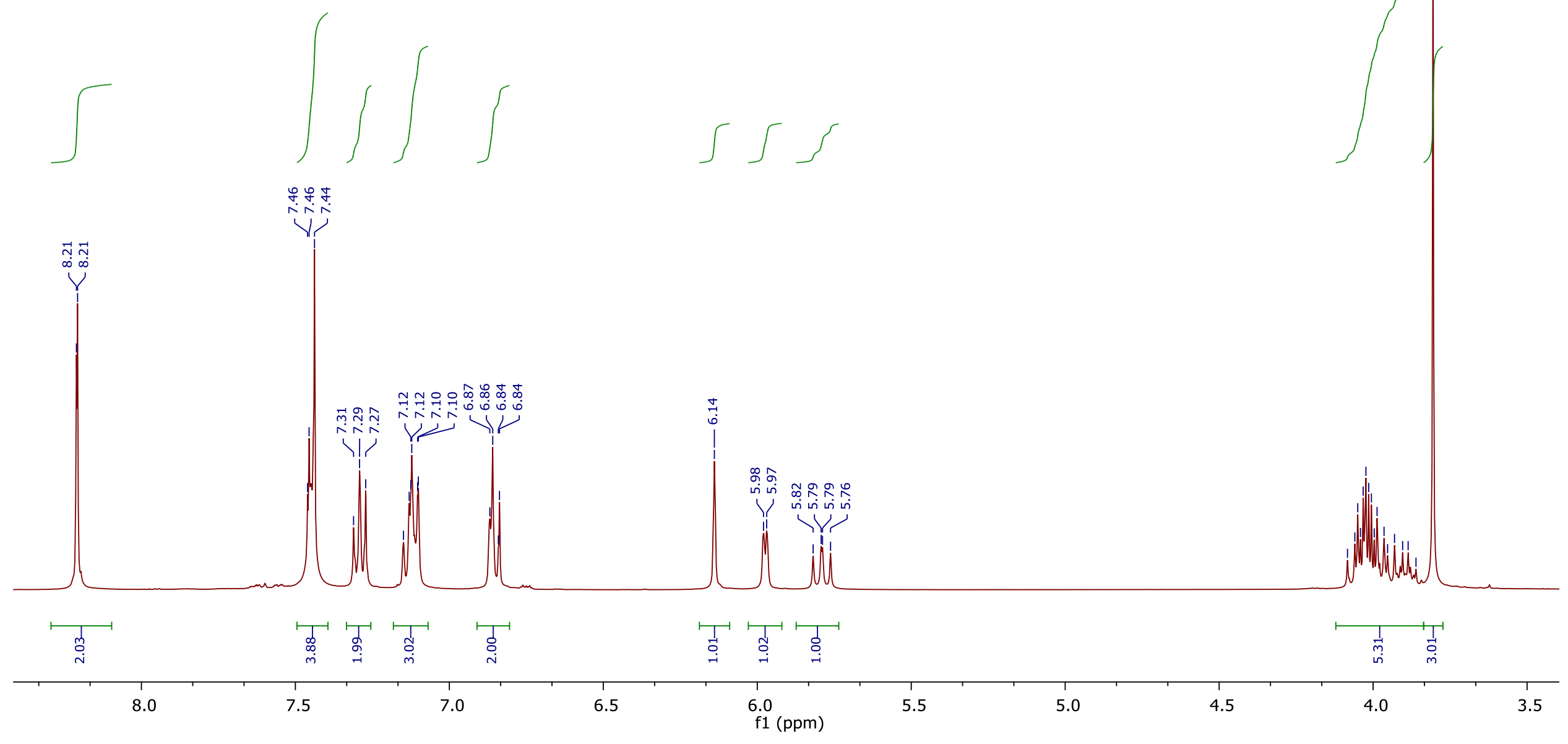


\section{${ }^{13} \mathrm{C}\left\{{ }^{1} \mathrm{H}\right\}$ NMR Spectrum of $\mathbf{1 b}$}

\begin{tabular}{lll} 
& \multicolumn{1}{c}{ Parameter } & \multicolumn{1}{c}{ Value } \\
1 & Solvent & DMSO \\
2 & Pulse Sequence & zgpg30 \\
3 & Experiment & $1 \mathrm{D}$ \\
4 & Number of Scans & 4096 \\
5 & Receiver Gain & 205.1 \\
6 & Relaxation Delay & 2.0000 \\
7 & Pulse Width & 10.0000 \\
8 & Acquisition Time & 1.3631 \\
9 & Spectrometer Frequency & 100.62 \\
10 & Spectral Width & 24038.5 \\
11 & Nucleus & $13 \mathrm{C}$ \\
12 Spectral Size & 65536
\end{tabular}

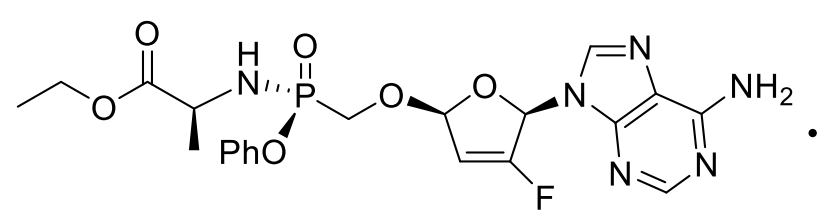

$1 \mathrm{~b}$<smiles>COc1cc(C(=O)O)ccc1O</smiles>

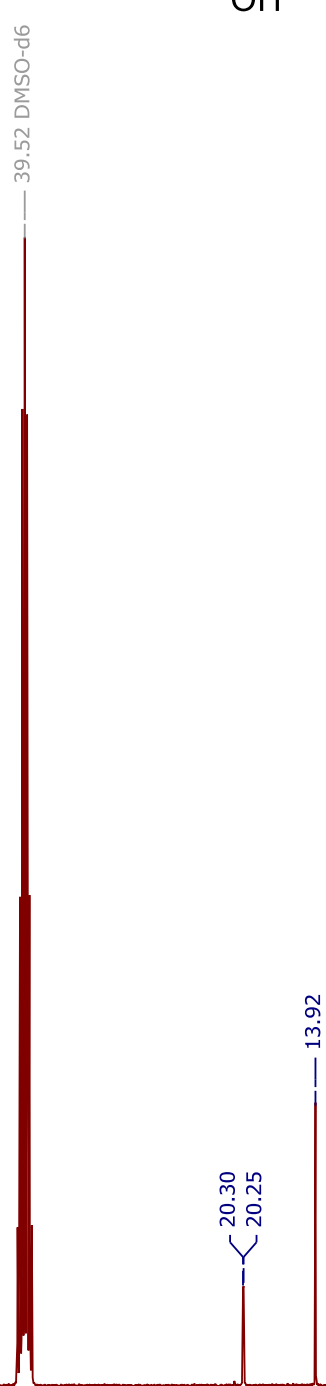

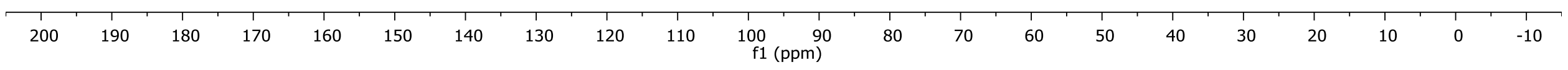


${ }^{19}$ F NMR Spectrum of $\mathbf{1 b}$

\begin{tabular}{lll} 
& \multicolumn{1}{c}{ Parameter } & \multicolumn{1}{c}{ Value } \\
1 & Solvent & DMSO \\
2 & Pulse Sequence & zgflqn \\
3 & Experiment & $1 \mathrm{D}$ \\
4 & Number of Scans & 64 \\
5 & Receiver Gain & 205.1 \\
6 & Relaxation Delay & 1.0000 \\
7 & Pulse Width & 18.0000 \\
8 & Acquisition Time & 0.7340 \\
9 & Spectrometer Frequency & 376.46 \\
10 & Spectral Width & 89285.7 \\
11 & Nucleus & $19 \mathrm{~F}$ \\
12 Spectral Size & 131072
\end{tabular}

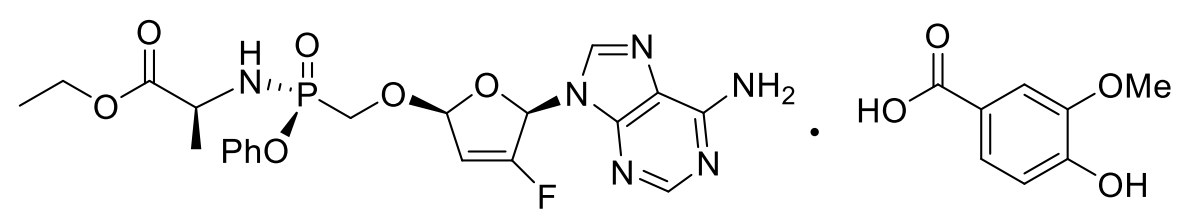

$1 \mathrm{~b}$
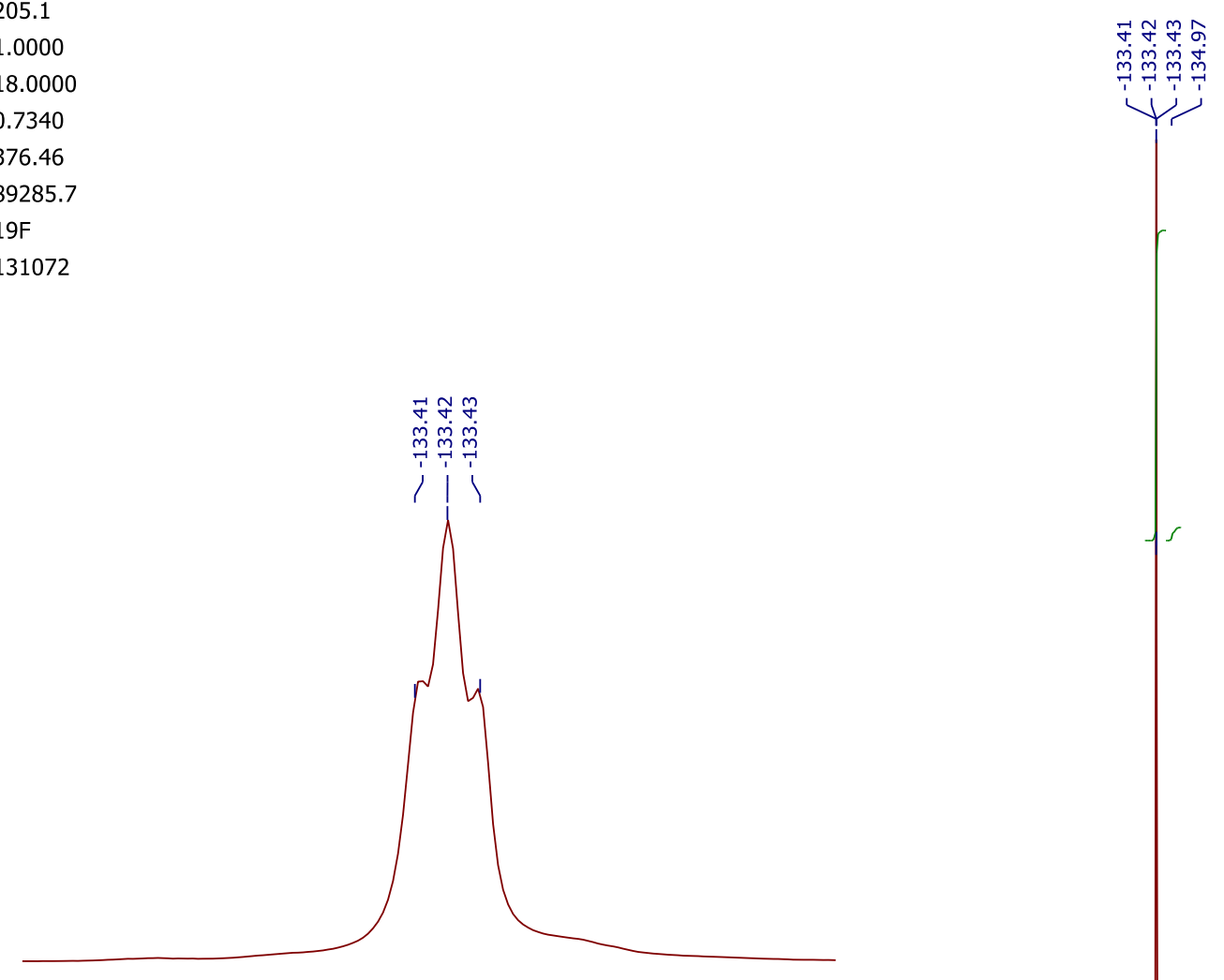

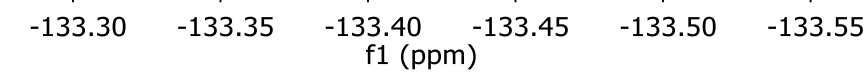

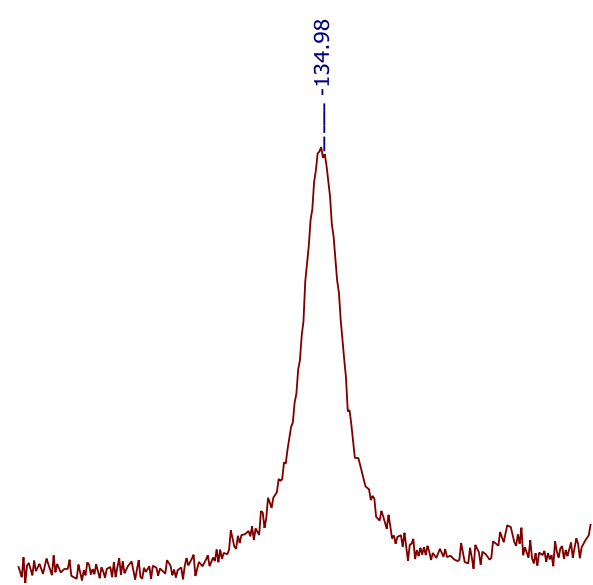

$-134.7-134.8-134.9-135.0-135.1-135.2$ f1 (ppm)

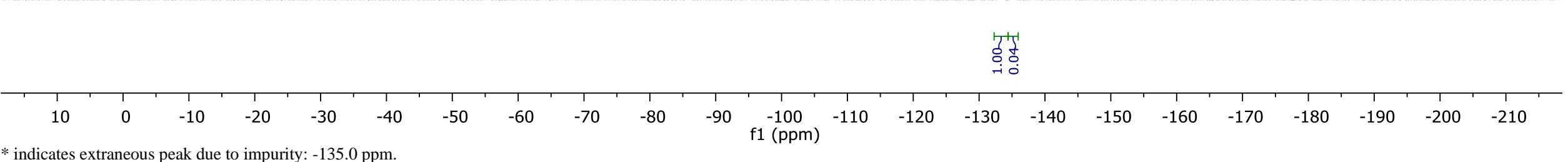

* indicates extraneous peak due to impurity: $-135.0 \mathrm{ppm}$. 


\section{${ }^{31} \mathrm{P}\left\{{ }^{1} \mathrm{H}\right\}$ NMR Spectrum of $\mathbf{1 b}$}

\begin{tabular}{lll}
\multicolumn{1}{c}{ Parameter } & \multicolumn{1}{c}{ Value } \\
1 & Solvent & DMSO \\
2 & Pulse Sequence & zgpg30 \\
3 Experiment & 1D \\
4 & Number of Scans & 64 \\
5 & Receiver Gain & 205.1 \\
6 & Relaxation Delay & 2.0000 \\
7 & Pulse Width & 8.0000 \\
8 & Acquisition Time & 0.5112 \\
9 & Spectrometer Frequency & 161.97 \\
10 Spectral Width & 64102.6 \\
11 Nucleus & $31 \mathrm{P}$ \\
12 Spectral Size & 65536
\end{tabular}

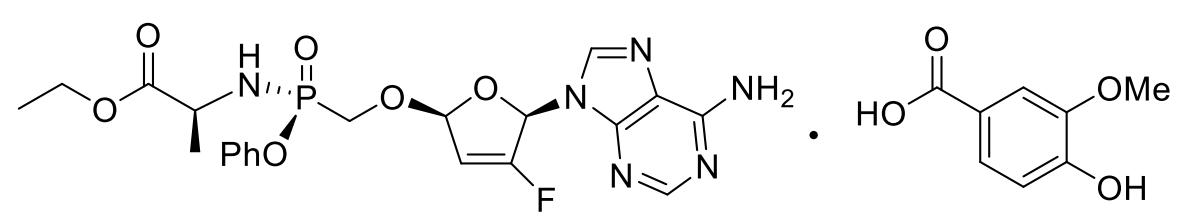

$1 b$

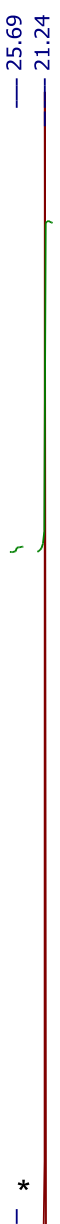

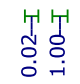

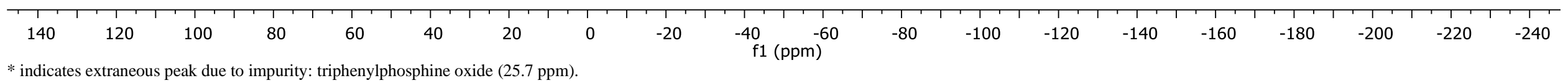


${ }^{1} \mathrm{H}$ NMR Spectrum of $\mathbf{1}$

\begin{tabular}{lll} 
& \multicolumn{1}{c}{ Parameter } & \multicolumn{1}{c}{ Value } \\
1 & Solvent & DMSO \\
2 & Pulse Sequence & zg30 \\
3 & Experiment & $1 \mathrm{D}$ \\
4 & Number of Scans & 32 \\
5 & Receiver Gain & 30.9 \\
6 & Relaxation Delay & 1.0000 \\
7 & Pulse Width & 10.0000 \\
8 & Acquisition Time & 4.0894 \\
9 & Spectrometer Frequency & 400.13 \\
10 & Spectral Width & 8012.8 \\
11 & Nucleus & $1 \mathrm{H}$ \\
12 Spectral Size & 65536
\end{tabular}

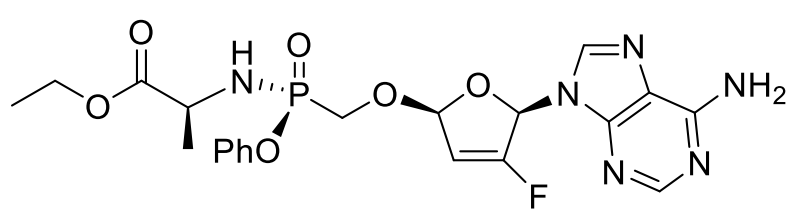

1

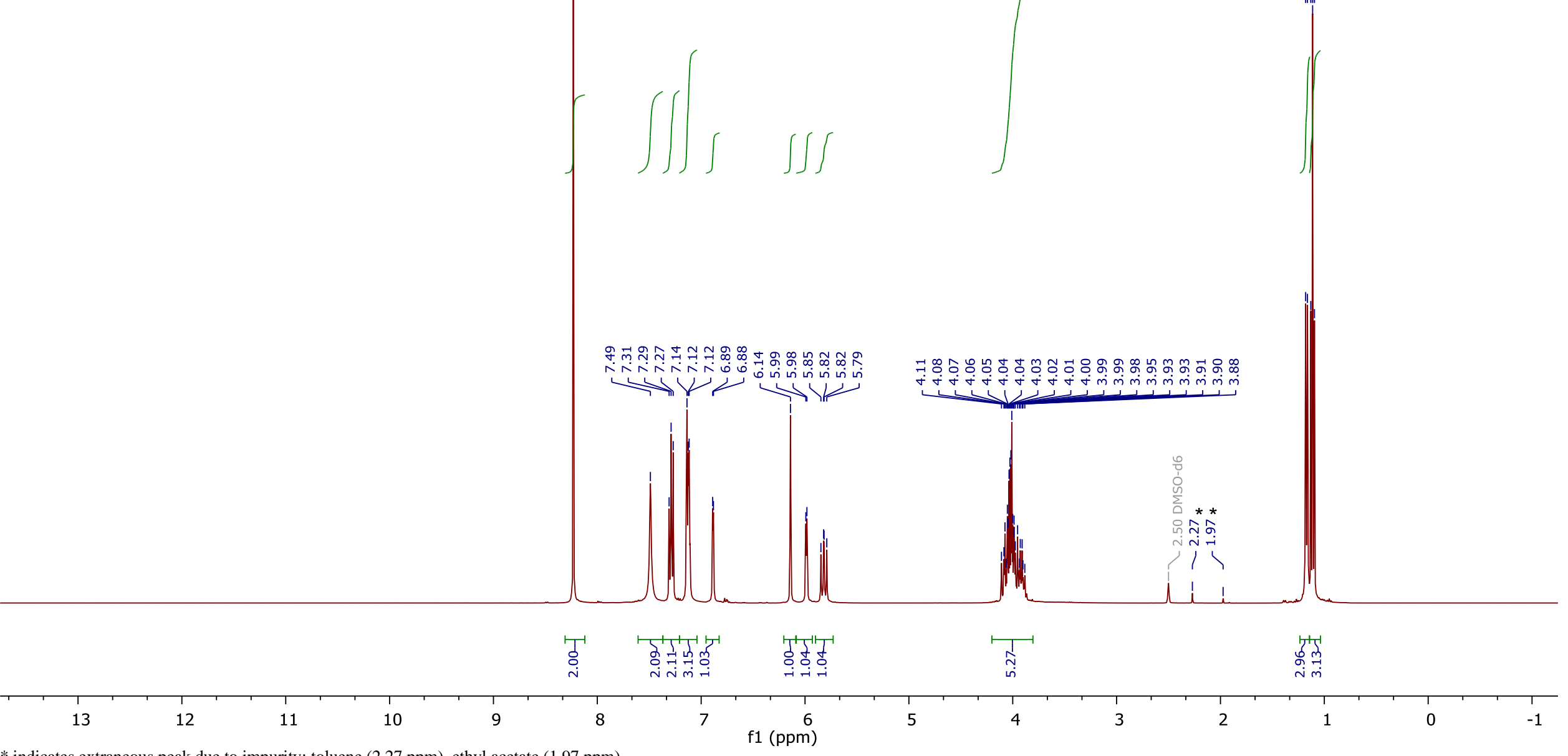

* indicates extraneous peak due to impurity: toluene (2.27 ppm), ethyl acetate (1.97 ppm). 
${ }^{1} \mathrm{H}$ NMR Spectrum of $\mathbf{1}$, expansion

\begin{tabular}{lll} 
& \multicolumn{1}{c}{ Parameter } & \multicolumn{1}{c}{ Value } \\
1 & Solvent & DMSO \\
2 & Pulse Sequence & zg30 \\
3 & Experiment & $1 \mathrm{D}$ \\
4 & Number of Scans & 32 \\
5 & Receiver Gain & 30.9 \\
6 & Relaxation Delay & 1.0000 \\
7 & Pulse Width & 10.0000 \\
8 & Acquisition Time & 4.0894 \\
9 & Spectrometer Frequency & 400.13 \\
10 & Spectral Width & 8012.8 \\
11 & Nucleus & $1 \mathrm{H}$ \\
12 & Spectral Size & 65536
\end{tabular}

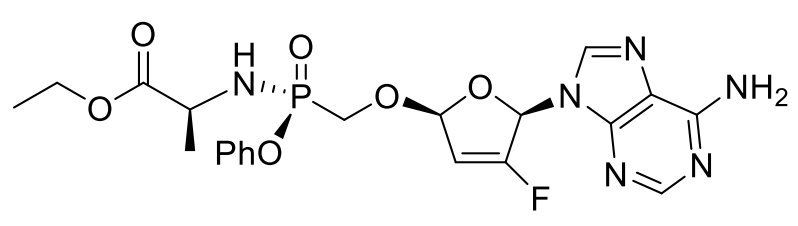

1

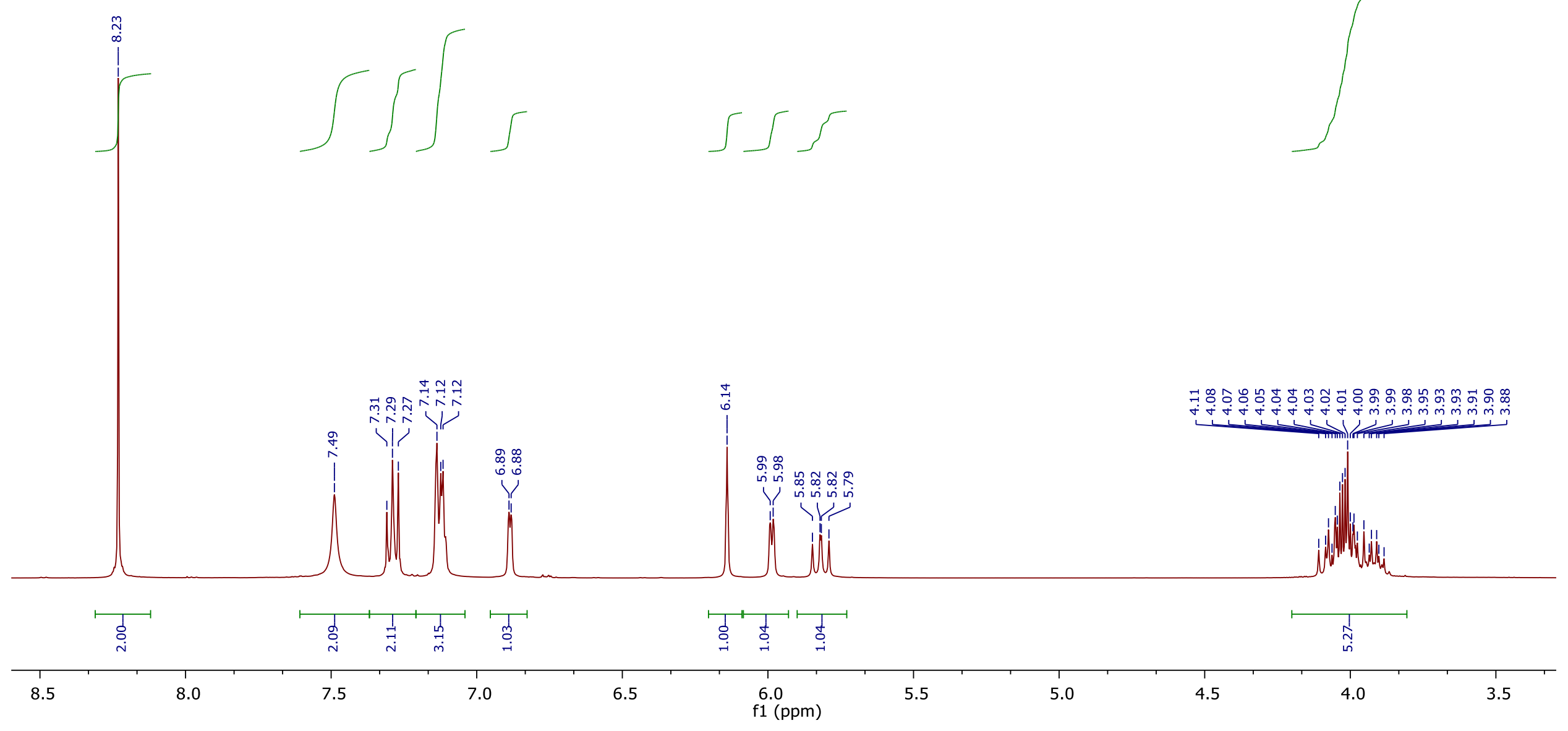


${ }^{13} \mathrm{C}\left\{{ }^{1} \mathrm{H}\right\}$ NMR Spectrum of $\mathbf{1}$

\begin{tabular}{lll} 
& \multicolumn{1}{c}{ Parameter } & \multicolumn{1}{c}{ Value } \\
1 & Solvent & DMSO \\
2 & Pulse Sequence & zgpg30 \\
3 & Experiment & $1 \mathrm{D}$ \\
4 & Number of Scans & 4096 \\
5 & Receiver Gain & 205.1 \\
6 & Relaxation Delay & 2.0000 \\
7 & Pulse Width & 10.0000 \\
8 & Acquisition Time & 1.3631 \\
9 & Spectrometer Frequency & 100.62 \\
10 & Spectral Width & 24038.5 \\
11 & Nucleus & $13 \mathrm{C}$ \\
12 & Spectral Size & 65536
\end{tabular}

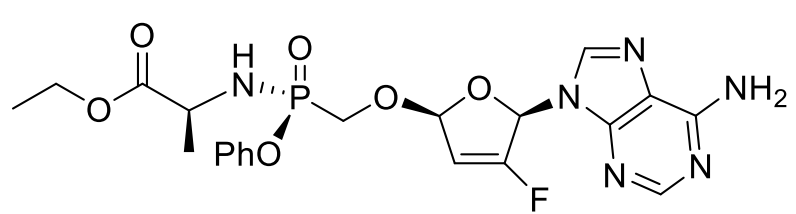

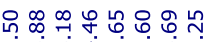

ปิ

(I) V

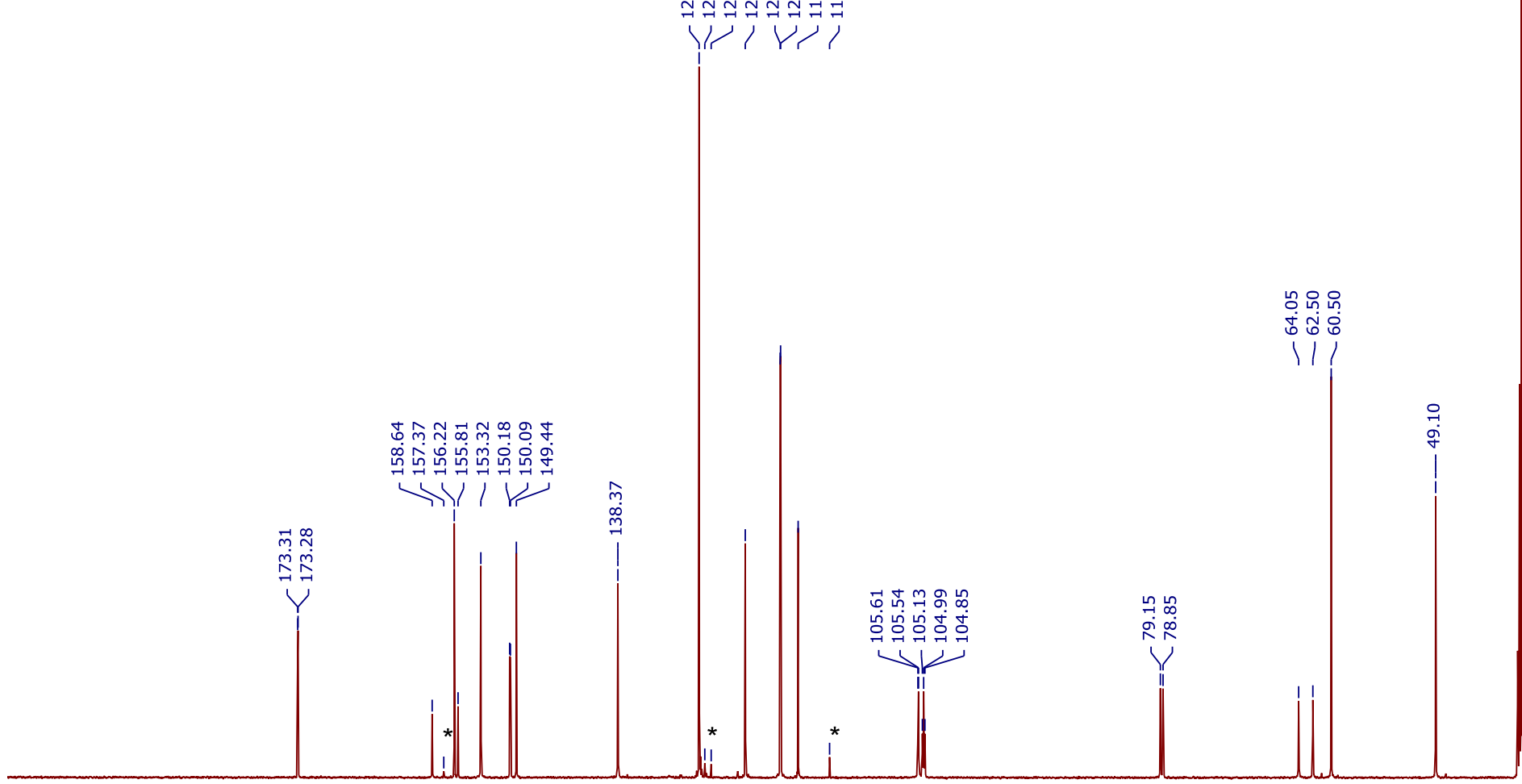

\begin{tabular}{lllllll}
\hline 200 & 190 & 180 & 170 & 160 & 150 & 140
\end{tabular}

* indicates extraneous peak due to impurity: 157.4, 128.9, 128.2, $115.3 \mathrm{ppm}$. 


\section{${ }^{19}$ F NMR Spectrum of $\mathbf{1}$}

\begin{tabular}{lll} 
& \multicolumn{1}{c}{ Parameter } & \multicolumn{1}{c}{ Value } \\
1 & Solvent & DMSO \\
2 & Pulse Sequence & zgflqn \\
3 & Experiment & $1 \mathrm{D}$ \\
4 & Number of Scans & 64 \\
5 & Receiver Gain & 205.1 \\
6 & Relaxation Delay & 1.0000 \\
7 & Pulse Width & 18.0000 \\
8 & Acquisition Time & 0.7340 \\
9 & Spectrometer Frequency & 376.46 \\
10 & Spectral Width & 89285.7 \\
11 & Nucleus & $19 \mathrm{~F}$ \\
12 Spectral Size & 131072
\end{tabular}

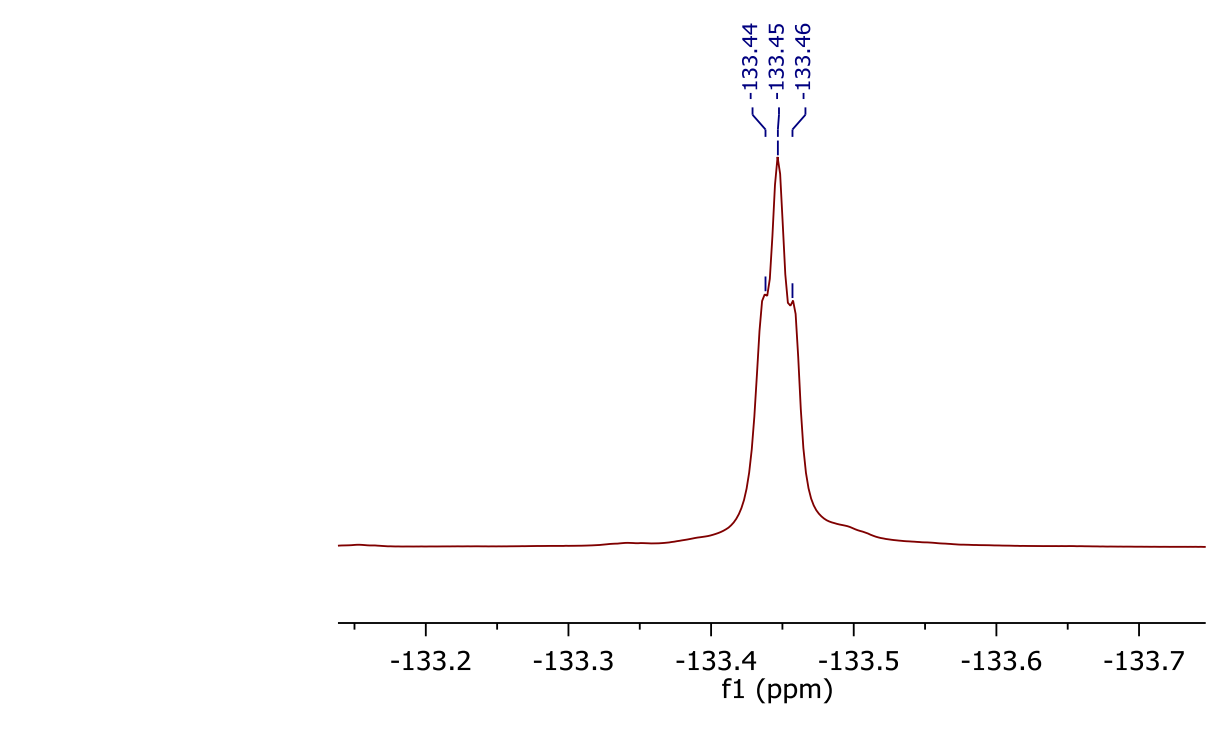

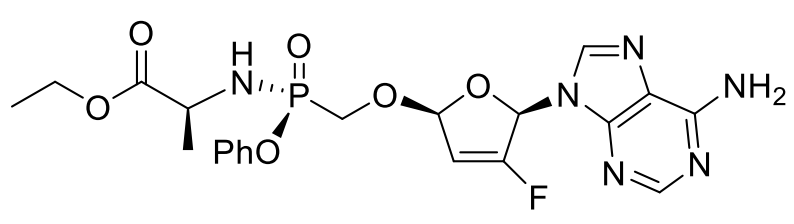

항 우웅워 웅

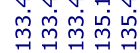

i

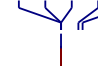

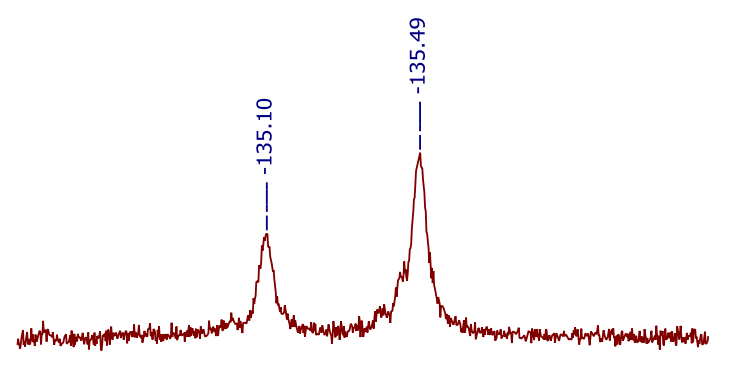

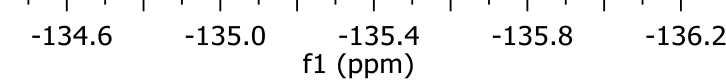

!

대윰엉 


\section{${ }^{31} \mathrm{P}\left\{{ }^{1} \mathrm{H}\right\}$ NMR Spectrum of $\mathbf{1}$}

\begin{tabular}{lll}
\multicolumn{1}{c}{ Parameter } & \multicolumn{1}{c}{ Value } \\
1 & Solvent & DMSO \\
2 & Pulse Sequence & zgpg30 \\
3 Experiment & $1 \mathrm{D}$ \\
4 & Number of Scans & 64 \\
5 & Receiver Gain & 205.1 \\
6 & Relaxation Delay & 2.0000 \\
7 & Pulse Width & 8.0000 \\
8 & Acquisition Time & 0.5112 \\
9 & Spectrometer Frequency & 161.97 \\
10 Spectral Width & 64102.6 \\
11 Nucleus & $31 \mathrm{P}$ \\
12 Spectral Size & 65536
\end{tabular}

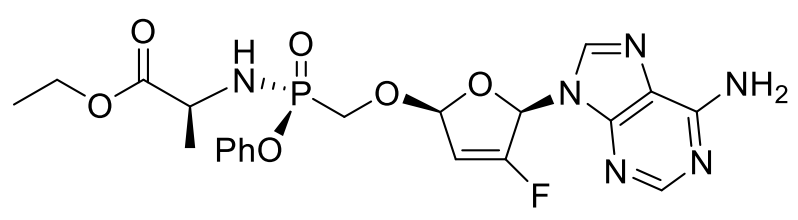

1

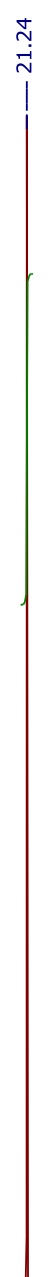

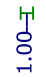

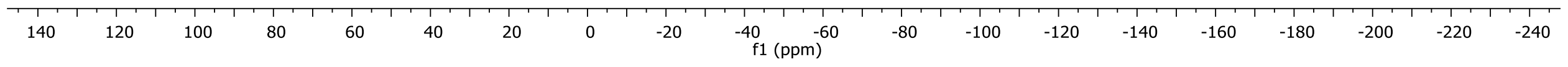

